\title{
A NEW INFRAGENERIC CLASSIFICATION AND SYNOPSIS OF THE GENUS VANILLA PLUM. EX MILL. (ORCHIDACEAE: VANILLINAE)
}

\author{
Miguel A. Soto Arenas $\dagger^{+1} \&$ Phillip CribB $^{2}$ \\ ${ }^{1}$ Laboratorio de Genética Molecular y Evolución, Instituto de Ecología, \\ Universidad Nacional Autónoma de México and \\ Herbario AMO, Montañas Calizas 490, México D.F. 11000, México \\ ${ }^{2}$ The Herbarium, Royal Botanic Gardens, Kew, Richmond, Surrey TW9 3AE, UK
}

\begin{abstract}
An updated, annotated checklist of the species of the genus Vanilla is presented, with information on nomenclature, distribution, literature and examined specimens. A key for the determination of the species is included. A new proposal of infrageneric classification of Vanilla is provided.

Resumen. Se presenta un listado actualizado, comentado de las especies del género Vanilla, donde se proporciona informacion nomenclatural, distribucional, literatura y especímenes examinados. Se incluye una clave para la determinación de las especies. Finalmente se presenta una nueva propuesta de la clasificación infragenérica de Vanilla.
\end{abstract}

KeY wORDS / PALABRAS CLAVE: Orchidaceae, Vanilla, checklist, listado, infrageneric classification, clasificación infragenérica

The pantropical genus Vanilla Plum. ex Mill. belongs to the subtribe Vanillinae and the subfamily Vanilleae, it comprises some 106 species of hemiepiphytic vinous orchids (Soto Arenas, 2003). Recent phylogenetic analyses have shown that it is closely related to the South American genera Dictyophyllaria Garay and Epistephium Kunth and to the achlorophyllous genus Lecanorchis Blume (Cameron, 1996; Cameron et al., 1999, Soto Arenas \& Alvarez-Buylla, in press).

Information on vanillas has been collected for a phylogenetic analysis, but since no modern revision exists, it has been necessary to evaluate the status of all the proposed taxa. The results of this survey are presented here, pending the production a formal revision.

Vanilla has proved to be a taxonomically difficult genus (Soto Arenas, 2003). The first species were named before the establishment of the binomial system of nomenclature (Linnaeus, 1753) and their nomenclature and typification is confusing. Some taxa were described from sterile material, and like other hemiepiphytic plants, vegetative traits vary greatly, rendering such characters difficult to use for determination. A particular problem is that several taxa have been described from immature buds, in which measurements, and shape of the segments can be substantially different from the morphology of the same features at anthesis, making identification uncertain. Furthermore, numerous species are known from a surprisingly small number of specimens, mostly due to the scarcity of available flowering material because of their irregular flowering and the ephemeral nature of the flowers, the positioning of the inflorescences in the canopy of the rain forests, and the low density of some populations. Vanillas from densely populated areas in the tropics apparently face severe conservation problems and their populations are often depleted. Additional complications are the poor preservation of the flowers in herbarium specimens, the flowers often rotting before they dry, and the presence of some complexes in which interspecific differentiation is subtle. A very large group of American species is pollinated by male Euglossine bees attracted by chemical compounds (Roubik and Ackerman, 1987; Dressler 1993; Soto Arenas \& Alvarez-Buylla, pers. obs.). In other orchids with similar pollination systems, there may there be little morphological differentiation, yet the species can be effectively separated by barriers imposed by the fragrance- 
collecting behavior of their pollinators (van der Pijl \& Dodson 1966).

Our knowledge of Vanilla is therefore far from adequate to produce a good, modern revision of the group, although there have been important contributions, such as two revisions of Vanilla (Rolfe, 1896; Portères, 1954), the treatment by Klotzsch (1845) and regional accounts by Hoehne (1945), Correll (1951), Cribb \& Hunt (1984), La Croix \& Cribb (1995), Luer (1972), Summerhayes (1968), Seidenfaden (1992), and Szlatchetko and Olzewski (1999). The revision by Portères, the last full account of the genus, although useful, is somewhat out-ofdate because, although we accept a similar number of species in this checklist compared with his revision (110 species), there are substantial differences. The description of several new species, improved collections of some poorly-known taxa clarifying their status, and our understanding of the distribution of the species and their phylogenetic relationships (Soto Arenas, 2003; Soto Arenas et al., unpublished results) have improved our understanding of the genus.

The fragmentary or poor material of some taxa available to Portères (1954) led him to propose affinities between taxa that belong to different lineages of the group. Therefore, the aims of this paper are to present a new classification of the genus based on cladistic analysis of morphological and molecular data presented elsewhere (Soto Arenas, 2003; Soto Arenas \& Alvarez-Buylla, in press), to present an updated checklist of the species and to stress where more information is needed. This revision will also allow the better identification of species and constitute a base for future research.

\section{Material and methods}

A bibliographic revision was conducted. Specimens were examined in the following herbaria: AMES, AMO, BM, F, G, K, L, NY, P, W. Special attention was paid to type and critical specimens, for example flowering material from type localities where the species were described from sterile or immature material. When possible, we examined cultivated and living wild specimens, spirit-preserved flowers, botanical illustrations and photographs. Affinities of many taxa have been assessed with the aid of molecular data, published elsewhere (Soto Arenas, 2003; Soto Arenas et al., in press).

\section{Infrageneric classification of Vanilla}

The genus Vanilla is a rather diverse assamblage of species of pantropical distribution. Despite the lack of morphological synapomorphies in the genus, there is strong molecular evidence that it is monophyletic (Soto Arenas \& Alvarez-Buylla, in prep., Cameron, unpubl. data). The following combination of characters are diagnostic for Vanilla: the hemiepiphytic vinous monopodial growth habit, with roots produced at each internode (these characters are found in some Galeolinae, a subtribe that may be considered part of Vanillinae, and Clemastepistephium N.Hallé), fleshy fruits and the wingless seeds with a hard seed coat (similar seeds are apparently found in Dictyophyllaria).

Vanilla is an ancient group, and most morphological groups within it are monophyletic and have defined geographic distributions. In many ways it is a very diverse genus compared with others in the Orchidaceae. Some authors might favor the idea that the genus should be split into more uniform assemblages with a more restricted geographic distribution. The type species, Vanilla mexicana, and most of Portères' section Membranacea could be easily considered as the genus Vanilla with the rest of the species separated in a different genus. Strong molecular and morphological information supports this view, although it is equally correct (in terms of recognizing monophyletic taxa) to consider all of them in a single genus, although it has few morphological synapomorphies.

The inner lineages of the genus may be supported by molecular characters, but most of them lack morphological synapomorphies that permit their recognition and we found that their acceptance as separate genera is not favoured by other authors. One of the main reasons to keep Vanilla in its traditional sense is to keep the traditional use of the name. The type species, $V$. mexicana, is in one of the two main clades, and the species cultivated for their aromatic fruits fall in the other one. To recognize both lineages as different genera would produce the following problems:

- The proposal of a new genus to accomodate the economically most important species in the 
Orchidaceae, to which the name "vanilla" or "vainilla" has been attached since pre-Linnean times.

- A new lectotypification of the genus, whose nomenclature has been historically complex, and conservation of the name for the cultivated species.

We believe that to keep Vanilla in its traditional sense is congruent with the phylogeny of the group and to maintain the nomenclatural stability that has now been reached.

Rolfe (1896) proposed a formal infrageneric classification of Vanilla, recognising two sections: Foliosae and Aphyllae. Portères (1954) accepted Rolfe's sections and, in Foliosae, proposed 3 subsections: Papillosae, Lamellosae and Membranacea. However, his subsections are invalid as he provided them with neither a Latin diagnosis nor a type. Furthermore, his sections and subsections are polyphyletic, except for subsection Membranacea which is paraphyletic (Soto Arenas, 2003).

Section Aphyllae is polyphyletic, because the leafless habit evolved independently at least four times in the genus, or maybe is the plesiomorphic condition for the clade containing the Caribbean-Paleotropical taxa, in which leafy species are also included. The leafless condition evolved independently at least once ( $V$. penicillata) in the clade of $V$. planifolia. If sect. Aphyllae is polyphyletic, then sect. Foliosae is also polyphyletic. These sections are also hierarchically incongruent, because they do not reveal the existence of the two main clades in the genus: the membranaceous species and all the others. Porterés included both $V$. wrightii $(=V$. bicolor $)$ and $V$. palmarum, the most basal species in the clade containing the American nonmembranaceous leafy species, and $V$. weberbaueriana $(=V$. ruiziana $)$ and $V$. pleei, to which he had no access to appropriate material (see comments under these species in the checklist) in subsect. Membranacea. Subsections Papillosae and Lamellosae are very heterogeneous and incongruent with our cladistic analyses.

In order to be congruent with the phylogenetic analyses, we propose Vanilla to be formed by two subgenera: Vanilla and Xanata. As defined here subgenus Xanata comprises two sections: Xanata and Tethya.

\section{Proposed classification of Vanilla}

The following classification is proposed here. Species groups are indicated in an informal way. They are easily recognized morphologically, but there is little evidence of their monophyly, and in some cases they may well be paraphyletic.

\section{A. Vanilla subgenus Vanilla}

Vanilla subsect. Membranacea Portères in Bouriquet, Le Vanillier et La Vanille: 159 (1959). nom. illeg.

Plants with membranaceous leaves. Inflorescences scarcely or not at all differentiated from vegetative axis. Lip without a penicillate callus. Column united to the lip only at the base. Column with a subperpendicular, protruding anther (incumbent only $90^{\circ}$ ), concave stigma, and smooth ventral surface. Type species: $V$. mexicana Mill.

Distribution: 15 species in the Neotropics, most diverse in southern Brazil.

Subgenus Vanilla has never been used as a name for this taxon, but it is automatically applicable to the group of $V$. mexicana Mill., the type species of the genus.

The genus Dictyophyllaria is practically identical in floral morphology to the $V$. parvifolia group. Its recollection and comparison with this subgenus and other Vanillinae is much needed.

Two groups can be recognized, but their limits are not clear-cut:

1. V. mexicana group: Petals undulate; sepals usually inrolled; lip very wide, 3- to 5-lobed, with a wide, obtuse apical lobe and numerous high keels or an elevated, very fleshy callus; and column lacking a basal triangular keel on the abaxial surface.

Species placed here include Vanilla costaricensis, $V$. guianensis, $V$. inodora, $V$. martinezii, $V$. methonica, $V$. mexicana, V. oroana and V. ovata.

2. V. parviflora group: Petals not undulate; sepals not inrolled; lip 3-lobed, with a rounded-quadrate apical lobe, a blade with axial rows of warts; and column with a basal triangular keel on the abaxial surface.

Species included here are $V$. angustipetala, $V$. parvifolia and $V$. verrucosa. Similar to these, but flowers larger with smooth keels, and an acuminate 
midlobe of the lip are V. bertoniensis, V. bradei, $V$. edwallii and $V$. organensis.

B. Vanilla subgenus Xanata Soto Arenas \& Cribb subgen. nov. a sectione typica plantis foliosis vel aphyllis; inflorescentiis elongatis ab surculo vegetato valde differt; callo penicellato labelli deficienti; columna ad labello medio adnata, latus adaxialis glaber vel pubescens; anthera ventralis ad columna parallela; lobis stigmatibus emergentibus distinguenda.

Typus: Vanilla planifolia G. Jackson.

Plants leafy or leafless. Leaves coriaceous-fleshy. Inflorescence a specialized axis, very different from vegetative ones. Lip with or lacking a penicillato callus. Column united to the lip usually more than a half of its length. Column with a parallel, somewhat ventral anther, emergent stigmatic lobes, and with a smooth or often hairy ventral surface.

Distribution: pantropical.

DeRIVATION OF THE NAME: from the Mexican Indian Totonaco name for Vanilla, "xanat" or "shanat". Totonaco Indians are thought to have brought Vanilla planifolia to cultivation.

\section{a. Vanilla subgen. Xanata sect. Xanata}

3. Vanilla palmarum group: Ovaries calyculate; flowers without a penicillate callus; lip rather entire and united to the column only about a half of column length, with longitudinal pubescent to hirsute lines on the distal half of the lip.

Distribution: West Indies and South America.

Species included here are $V$. bicolor, $V$. palmarum and V. savannarum.

4. V. trigonocarpa group: Lip very inflated with much crenulate margins; vegetative habit mesophytic; racemes few-flowered; flowers very fragrant, small to huge; fruit trigonous, very long and fleshy. Probably a grade rather than a clade.

Distribution: Tropical America, from Costa Rica to Amazonia.

Species included here are $V$. espondae, $V$. hartii, $V$. sprucei and $V$. trigonocarpa.
5. V. planifolia group: Flowers greenish; lip concave and with small papillae in the apical region. The South American species have an apical callus connected with the penicillate callus in the middle of the lip by rows of papillae and with the lip apex usually recurved

Distribution: Widespread in Tropical America, including the West Indies.

Species included here are $V$. appendiculata, $V$. bahiana, V. cristagalli, $V$. denticulata, V. dubia, $V$. dungsii, V. fimbriata, V. helleri, V. insignis, V. odorata, V. phaeantha, V. planifolia, V. ribeiroi, V. schwackeana, $V$. tahitiensis and $V$. uncinata.

6. V. penicillata group: Plants leafless, but related to the American leafy, penicillate species. Petals subunguiculate, lip long-unguiculate, with penicillate callus, and villose apex. Fruit calyculate. Similar to the leafy $V$. ribeiroi and, except by the leafless condition, belonging to the $V$. planifolia group.

Distribution: Guyana-Amazonia.

The only species included here is $V$. penicillata.

7. V. hostmanii group: Flowers large, usually white with a yellow-orange lip; lip with thickened, radiating veins on the distal half that can be somewhat warty (the warts rounded and flattened); inflorescences with rather distichous bracts; Ovary, sepals, and petals granulosely keeled, very conspicuously so in some species; Lip surface puberulent-cellular-papillose in some species; perianth segments sometimes with crystal druses included.

Distribution: Widespread in Tropical America, except for the West Indies.

Species included here are V. cribbiana, $V$. dressleri, $V$. gardneri, $V$. hostmannii and $V$. ruiziana.

8. V. pompona group: Leaves very fleshy; stems thick, xerophytic; lip rather smooth, except for the penicillate callus, and with a slightly thickened axial cushion running from the penicillate callus to the apex; flowers strongly fragrant, yellow with an orange lip; fruits thick, trigonous, banana-like.

Distribution: Widespread in Tropical America, except for the West Indies.

Species included here are $V$. calyculata, $V$. 
chamissonis, V. columbiana, $V$. grandiflora, $V$. pompona, $V$. pseudopompona and $V$. vellozii.

b. Vanilla subgen Xanata sect. Tethya Soto Arenas \& Cribb, sect. nov. a sectione Xanata foliis absentiis vel praesentis, carnosis vel coriaceis; ovario non calycoso; floribus saepe labelli callo penicillato ornatis; labello manifeste vel obscure trilobato, ad columna liberato, in partim apicali lineis pubescentibus destituto distinguenda.

Typus: Vanilla phalaenopsis Rchb. f. ex van Houtte.

Derivation of the name: From the ancient Tethys Sea, thought to be the migration route of Vanilla into the Palaeotropics.

9. V. kinabaluensis group: Leaves usually very broad, elliptic; stems terete; inflorescences multi-flowered, in some species with up to 150 flowers ( $V$. abundiflora and $V$. kinabaluensis); ovary stout, especially in New Guinean species; fruit thick and relatively short; tepals concolorous, greenish-yellowish, usually obtuse; lip cuneate or cuneate-flabellate in some New Guinean species, trumpet-shaped, not unguiculate, more or less trilobed, with the midlobe often recurved and with rows of reddish subulate papillae that may be very long and flattened in $V$. kinabaluensis, or whitish and longer in $V$. siamensis. Most species of this group are seldom collected and many are imperfectly know, but several of them seem to be closely related or maybe conspecific. The group is much more developed in the Malay Archipelago and New Guinea.

Distribution: From S China to New Guinea, most abundant in Indonesia.

Species included here are $V$. abundiflora, $V$. giullianetii, $V$. kaniensis, $V$. kempteriana, $V$. kinabaluensis, V. klabatiensis, V. ovalis, V. platyphylla, $V$. ramificans, $V$. siamensis, $V$. seranica, $V$. sumatrana, V. utteridgei and $V$. wariensis.

10. V. albida group: An Asiatic group with flowers and plants similar in appearance to the American $V$. planifolia group; flowers greenish white; lip longunguiculate; tepals long; and lip with short apical papillae. Some species, such as $V$. moonii and $V$. yersiniana, and perhaps other have sulcate stems in the way of $V$. insignis. V. albida, $V$. andamanica,
V. montana and $V$. yersiniana are closely related, differing in morphological details and distribution. $V$ havilandii seems to belong here, but has a very different inflorescence, bearing very small flowers. $V$. moonii has buff-colored tepals and yellow lip with apical papillae arranged in two rows, representing perhaps a shared character with $V$. annamica and $V$. somai.

Distribution: Sri Lanka to SE Asia and the Malay Archipelago across to Borneo.

Species included here are V. albida, V. andamanica, V. havilandii, V. montana, V. moonii, V. sanjappae and V. yersiniana.

11. $\boldsymbol{V}$. annamica group: Inflorescences very distinct, paniculate, bearing biflorous cymes; flowers trumpetshaped; and the lip has two apical, parallel rows of papillae.

Distribution: S China, Taiwan and Indochina.

Species included here are $V$. annamica and $V$. somai.

12. V. griffithii group: V. palembanica is very imperfectly known, but it seems to be allied to $V$. griffithii. Leaves broadly elliptic; flowers with very obtuse tepals, a lip with a deeply retuse midlobe, woolly rather than scaly penicillate callus, and truncate buds.

Distribution: Sumatra, Borneo and peninsular Malaysia.

Species included here are $V$. griffithii and $V$. palembanica.

13. V. borneensis group: Callus penicillate, continuous with the pilose lip apex; plants with small, narrow leaves and short inflorescences; lip with a pair of corpuscles at base. They seem to be leafy versions of the $V$. aphylla-V. calopogon- $V$. wightii group.

Distribution: From India and SE Asia to Indonesia.

Species included here are $V$. borneensis and $V$. diabolica.

14. V. imperialis group: Flowers large; lip trumpetshaped, similar to that of the V. planifolia group but shorter; callus absent; lip apex papillate. 
Distribution: Continental Africa.

Species included here are $V$. grandifolia, $V$. imperialis, $V$. ochyrae and V. polylepis.

15. V. françoisii group: Flowers very small, whitish green with the lip rose-tinted at the base and with purple margins; lip entire or six-lobed, densely covered with fleshy hairs or papillae in middle and front.

Distribution: Madagascar.

Species included here are $V$. françoisii and $V$. coursii.

16. V. chalotii group: Lip sacciform; midlobe reduced, recurved; side lobes well developed.

Distribution: West and equatorial Africa.

Species included here are $V$. chalotii, $V$. nigerica and $V$. seretii.

17. V. africana group: Lip not sacciform; side lobes of lip united to the basal $1 / 2-2 / 3$ of the column and forming deep sinuses with the mid=lobe; callus formed by scales or warts; column apex exposed.

Distribution: West and equatorial Africa, with a single species in Eastern Africa.

Species included here are V. acuminata, V.africana,
V. crenulata, V. cucullata, V. hallei, V. heterolopha, V. ramosa and $V$. zanzibarica.

18. V. barbellata group: Flowers green to greenish with a reddish-purplish lip; callus incipient, penicillate.

Distribution: Caribbean.

Species included here are V. bakeri, V. barbellata, $V$. claviculata, V. dilloniana and $V$. poitaei.

19. V. aphylla group: Lip with very long trichomes and sometimes an incipient penicillate callus. Scarcely different from $V$. borneensis group, except for the lack of leaves.

Distribution: India to the Philippines.

Species included here are V. aphylla, V. calopogon and $V$. wightii.

20. V. phalaenopsis group: Lip flabellate with two rows of hairs besides the axial line; petals obtuse, very wide.

Distribution: Indian Ocean basin (East Africa, Comores, Mascarene Islands, Madagascar, with a single species in Sri Lanka and S India).

Species included here are Vanilla decaryana, $V$. humblotii, V. madagascariensis, V. phalaenopsis, $V$. perrieri, $V$. roscheri and $V$. walkeriae.

\section{KeY TO VANILLA}

1. Plants leafless, sometimes the new stems bearing small scars or short leaves (much shorter than the internodes, fugaceous and absent in older stems, bracts of the inflorescence

Key I

1. Plants leafy, the blades well-developed and persisting several years, bracts persistent until the fruit ripens ........... 2

2. Leaves soft, membranous, very thin in herbarium specimens; lip margins united to the column only at base for less than $4 \mathrm{~mm}$; penicillate callus absent

Key II

2. Leaves coriaceous, fleshy, often chartaceous in dry condition; lip margins united to the column more than $1 / 3$ of column length, usually for more than $8 \mathrm{~mm}$; penicillate callus absent, wanting or often present

3. Lip deeply saccate at base Key III

3. Lip not saccate at the base 4

4. Stem $4 \mathrm{~mm}$ in diameter; leaves very small, $2 \mathrm{~cm}$ or less long, much shorter than the internodes 5

4. Stem stouter, $5 \mathrm{~mm}$ or more in diameter; leaves much larger, usually more or less as long as the internodes or longer

5. Lip side lobes lacerate or deeply erose on front margin, the central callus on lip circular, densely papillate, the mid=lobe of lip densely papillate V. penicillata

5. Lip crenulate towards apex, the disc densely hairy V. françoisii

6. Lip hexagonal in outline V. coursii 
6. Lip entire to 3-lobed

7. Lip 3-lobed in basal half .

7. Lip entire or 3-lobed in apical half

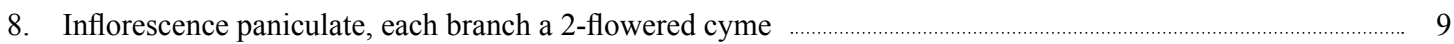

8. Inflorescence racemose or, if branched, then branches not 2-flowered

9. Lip hexagonal

9. Lip not hexagonal

10. Lip entire, broadest in middle, callus densely papillose, running from base of lip almost to tip ……...... V. annamica

10. Lip 3-lobed, broadest across the apex; callus on disc, elongate-elliptic, papillose, with a few scattered papillae on the mid=lobe

V. somai

11. Lip disc lacking a central almost quadrate tuft of erose or lacerate callus; callus papillose, hairy or of several erose or papillose ridges running the length of the lip

Key V

11. Lip with a central tufted or convex callus

12. Lip cuneate or cuneate-flabellate, lacking a prominently narrowed claw when spread flat, usually 1.5 times as long as broad or less; species from Old World

Key VI

12. Lip with a prominent narrowed claw when spread; lip usually more than 1.5 times as long as broad ........... Key VII

\section{KEY I}

1. Inflorescences subcorymbose, very long; bracts deciduous; flowers white, yellow or greenish with pink or maroon blotches deep in the throat of the lip; petals much broader than sepals; penicillate callus absent, but with rows of longitudinal papillae; species from the Indian Ocean basin: E Africa, Madagascar, Sri-Lanka, India, Seychelles, Comoros

1. Inflorescences racemose; flowers greenish-white, often flushed or blotched with purple; lip with a penicillate callus and other trichomes towards the apex; species from America

2. Column of $14-17 \mathrm{~mm}$ long; sepals $25-30 \mathrm{~mm}$ long V. decaryana

2. Column $18-30 \mathrm{~mm}$ long; sepals $50-70 \mathrm{~mm}$ long. 3

3. Flowers white with a yellow throat; veins of the petals and lip thin, almost straight .......................... V. walkerae

3. Flowers white with an apricot or pink throat or yellow with orange or maroon markings in the throat of the lip; veins of the petals and lip partially or totally sinuous-undulate

\section{4}

4. Column $27-30 \mathrm{~mm}$; lip covered with long, scattered hairs in the middle, veins slightly flexuous in the petals and the upper half of the lip; flowers yellow with the throat of the lip maroon or orange

4. Column 18-23 mm; disc of the lip adorned with 2 lines of long papillae or fleshy hairs; veins of the petals and lip all very sinuous-flexuous; flowers white, the lip a pink-reddish blotch on the throat

\section{6}

5. Lip papillose; column $20 \mathrm{~mm}$ long

V. humblotii

5. Lip not papillose; column $27-30 \mathrm{~mm}$ long V. perrieri

6. Sepals $75-80 \mathrm{~mm}$ long; stem $12-20 \mathrm{~mm}$ in diamet. V. roscheri

6. Sepals 50-65 $\mathrm{mm}$ long; stem $8-10 \mathrm{~mm}$ in diam.

7. Lip oblong, acute, the margins undulate V. phalaenopsis

7. Lip obovate, obtuse, the margins not undulate V. madagascariensis

8. Stems slender, usually less than $5 \mathrm{~mm}$ in diam. when mature in living condition; penicillate callus well-defined; column fused to the lip margins until stigmatic region; margins of the obscure lateral lobes of the lip laceratefimbriate, lip more than $50 \mathrm{~mm}$ long; Amazonian plants

V. penicillata

8. Stems thick, about $1 \mathrm{~cm}$ or more in diam. when mature in living condition; lip less than $50 \mathrm{~mm}$ long; lip apical margins crenulate, undulate or entire, not lacerate-fimbriate; Caribbean plants

9. Leaf present at each internode, persistent, to half or more the length of the internode, leaves plane, apices hooked; lip green with maroon margin and veins, hairs yellow, margins irregular V. poitaei 
9. Leaves not present at each internode, most or early deciduous, usually much less than half the length of the internode, leaf margin at least somewhat revolute, apices straight, curved, or hooked; lip not colored as above, margins more or less entire

10. Lip entire, broadly rounded at apex, with simple or forked flattened hairs along longitudinal rows in the middle of the lip to the apex, stem squarish

V. claviculata

10. Lip shallowly or deeply 3-lobed, without scale-like or flattened hairs to the lip apex

11. Lip less than $4 \mathrm{~cm}$ long, deeply 3 -lobed at the truncate apex, with sinuses prominent V. barbellata

11. Lip more than $4 \mathrm{~cm}$ long, broadly rounded above with a projecting apical lobe, without distinct

V. dilloniana

\section{KEY II}

1. Tepals contorted; flowers medium to large sized; lip $30 \mathrm{~mm}$ or more long, 3-lobed or entire

1. Tepals not contorted but occasionally slightly undulate; flowers small; lip less than $30 \mathrm{~mm}$ long, neatly 3-lobed

2. Lip entire, pentagonal or hexagonal

2. Lip 3-lobed

3. Lip $<5 \mathrm{~cm}$ long, with basal, warty keels, species from Guatemala

V. martinezii

3. Lip $>5 \mathrm{~cm}$ long, basal veins of the lip smooth, species from Amazonia and Guyanas

V. guianensis

4. Midlobe of the lip strongly emarginate

4. Midlobe of the lip broadly elliptic, ovate, subquadrate

5. Lip with a high, axial, fleshy, cushion-like callus V. inodora

5. Lip with 3-keeled callus, converging and thickened and rugose near the apex

6. Bracts small, 5.0-7.5 mm long; lip not papillose

V. methonica

6. Bracts foliaceous, $110-150 \times 65-71.5 \mathrm{~mm}$; lip papillose

V. oroana

7. Midlobe of the lip triangular, elongate, acuminate 8

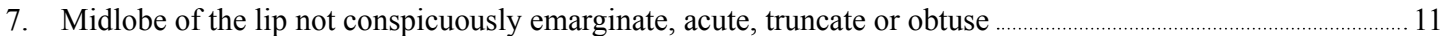

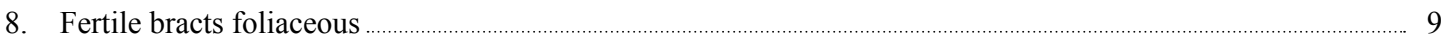

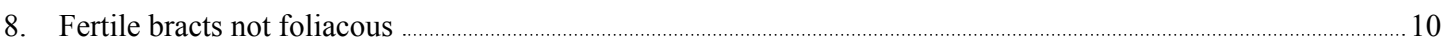

9. Lip distinctly 3-lobed, $29 \mathrm{~mm}$ long …….. bradei

9. Lip obscurely 3-lobed, 30-37 mm long .............................................................................................. . organensis

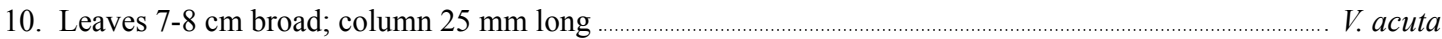

10. Leaves $5-7 \mathrm{~cm}$ broad; column $20-25 \mathrm{~mm}$ long

V. bertoniensis

11. Midlobe of the lip very short, quadrate, truncate, scarcely extending beyond the lateral ones ....... V. costaricensis

11. Midlobe of the lip ovate-elliptic, conspicuously longer than the lateral ones ……................................... 12

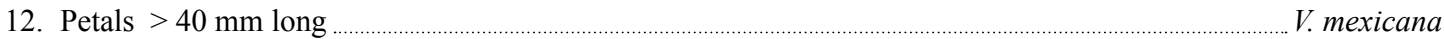

12. Petals $<38 \mathrm{~mm}$ long _............................................................................................................................................ V. ovata

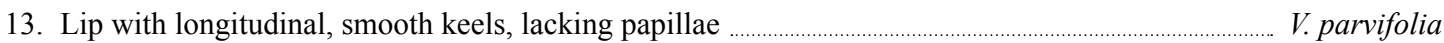

13. Lip with rows of papillae and keels ............................................................................................................................. 14

14. Lip $20 \mathrm{~mm}$ long ................................................................................................................................. V. verrucosa

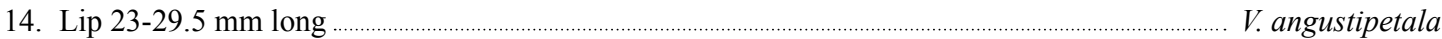

\section{KEY III}

1. Flowers small; sepals $<22 \mathrm{~mm}$ long; lip conspicuously 3-lobed, the midlobe very short and recurved .... V. chalotii

1. Flowers large; sepals $>34 \mathrm{~mm}$ long; lip obscurely 3-lobed, the midlobe very broad; stems papillose-verrucose $\ldots 2$

2. Lip midlobe strongly recurved-inrolled, the base saccate but without 2 gibbae, the throat slightly hairy. $V$. sereti

2. Lip midlobe recurved, but not rolled, the base with 2 gibbae, the throat densely and coarsely hairy.... $V$. nigerica 


\section{KEY IV}

1. Lip mid-lobe deeply emarginate with a fleshy inverted U-shaped callus around the sinus; callus on disc papillose; column straight; lip margins united to column in basal third only; species from Asia V. griffithii

1. Lip apical lobe acute or truncate; lip callus not papillose; column strongly arcuate; lip margins united to the column for only $2 / 3$ of column length or less, leaving the column apex very exposed; species of continental Africa

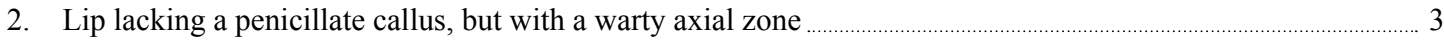

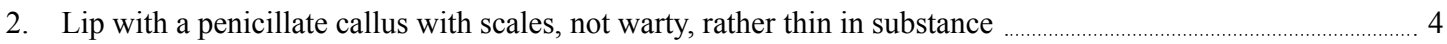

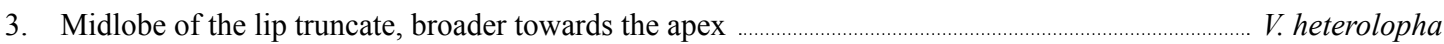

3. Midlobe of the lip acute to acuminate, broader towards the base, thick, fleshy; callus tuberculate, fleshy, half length of midlobe

4. Leaves small, long cuspidate; raceme dense, simple; midlobe of the lip oblong or obovate-elliptic, not axially thickened on the lower half ; callus a tuft of raised toothed crests

4. Leaves large, elliptic, acuminate; raceme lax to subdense, simple or branched 6

5. Mid-lobe of the lip oblong or obovate-elliptic, not axially thickened on the lower half V. africana

5. Mid-lobe of the lip oblong-elliptic, with an axial, thickened keel in the basal half

V. cucullata

6. Basal bracts of the inflorescence leaf-like, usually broadly elliptic to suborbicular; inflorescence usually simple; lip blade strongly gibbose-conduplicate, with a penicillate callus at the top of the gibba

V. crenulata

6. Basal bracts of the inflorescence inconspicuous, scale-like; inflorescence simple or branched 7

7. Lip blade slightly gibbose, strongly apiculate at tip; leaves elliptic to very broadly elliptic; species from Kenya, Tanzania, Uganda

V. zanzibarica

7. Lip blade not gibbose, lip obtuse, apiculate; leaves oblong to elliptic; species from western Africa V. acuminata

\section{KEY V}

1. Lip callus a more or less circular papillose mound; lip mid=lobe deeply emarginated, the margins of the sinus swollen into a U-shaped callus

V. griffithii

1. Lip not as above

2. Lip central callus of long fine hairs, mid=lobe covered with long fine hairs

V. sanjappae

2. Lip central callus elongate-oblong, of papillae, dendritic hairs of irregularly lacerate low ridges; mid-lobe of papillae, ridges or glabrous 3

3. Leaves oblong-elliptic, up to $21 \mathrm{~cm}$ long and $8 \mathrm{~cm}$ broad, rather succulent; floral bracts less than $1.5 \mathrm{~cm} \ldots \ldots . . V$. polylepis

3. Leaves elliptic to subcircular; floral bracts more than $1.5 \mathrm{~cm}$ long

4. Inflorescence not closely imbricate, leaves more than $30 \mathrm{~cm}$ long, very thin-membranaceous in dried specimens

V. grandifolia

4. Inflorescence bracts closely imbricate (Costus-like); leaves less than $25 \mathrm{~cm}$ long 5

5. Lip apex triangular V. imperialis

5. Lip apex elliptic to semi-circular V. ochyrae

\section{KEY VI}

1. Inflorescences simple, elongate, usually as long as or longer than the leaves, up to 200-flowered; flowers cream

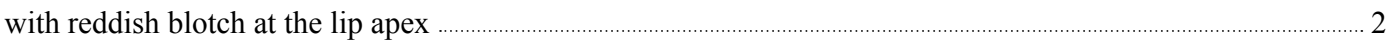

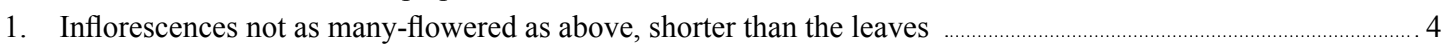

2. Lip 3-lobed, broadest in middle when flattened; mid-lobe of lip with a papillate longitudinal central ridge 
2. Lip almost entire, cuneate; mid-lobe of lip lacking a longitudinal papillate ridge

3. Column with dendritic hairs below stigma; apex of lip with a horseshoe shaped callus with a lacerate margin

3. Column glabrous; apex of lip with a V-shaped callus of papillae

V. abundiflora

4. Inflorescence branched, leaves oblong, small, $<10 \mathrm{~cm}$ long

V. kinabaluensis

4. Inflorescence simple, leaves usually ovate-elliptic, often very large (e.g. $20 \mathrm{~cm}$ long) V. ramificans

5. Flowers with yellow-throated lip, apical papillae conspicuous, flattened 5

5. Flowers conspicuously purple-red blotched on the lip, at least in the papillae area V. siamensis

6. Lip cuneate-flabellate, not or obscurely 3-lobed, species from New Guinea only 6

6. Lip cuneate, neatly 3-lobed, species from Philippines to Moluccas and New Guinea 7

7. Lip with a pair of rounded calli at the base 11

7. Lip lacking any basal corpuscular calli V. diabolica

8. Column hairy on ventral surface facing the lip V. utteridgei

8. Column glabrous 9

9. Lip apical margins lacerate-irregularly erose V. kempteriana

9. Lip apical margin not lacerate or erose 10

10. Lip as broad as long, apex shallowly emarginate

V. kaniensis

10. Lip longer than broad, apex more or less rounded

V. wariensis

11. Stem quadrate or terete in cross-section; flower not concolorous …......................................................................... 12

11. Stem sulcate; flowers greenish, white, cream, or tanned, usually concolorous …………………................... 16

12. Stems angular in cross-section

V. giullianetii

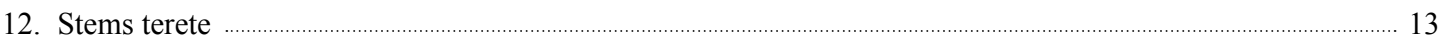

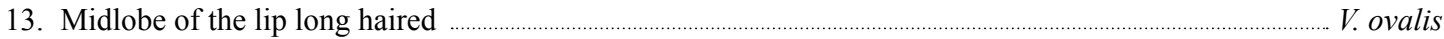

13. Midlobe of the lip papillose to short-haired ..................................................................................................... 14

14. Column pubescent on inner surface; lip disc papillate at base …..................................................... V. platyphylla

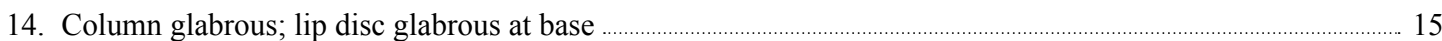

15. Lip mid=lobe slightly emrarginate; callus on mid-lobe oblong, densely papillose …........................... V. sumatrana

15. Lip mid=lobe subacute; mid-lobe sparsely papillose all over $\quad V$ seranica

16. Inflorescence very dense, many-flowered, usually more than 30 -flowered, tepals greenish, flowers small; lip less than $3 \mathrm{~cm}$ long

V. havilandii

16. Inflorescence not very dense, with more than 15 flowers; tepals greenish, white-cream to tanned; flowers larger; lip more than $3.5 \mathrm{~cm}$ long

17. Tepals tan-colored; lip buff-colored; species from Sri Lanka ….................................................................. V. moonii

17. Tepals greenish, cream or white; species from Andaman Islands to Indonesia …...................................................... 18

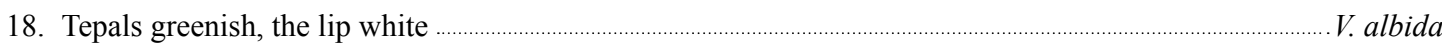

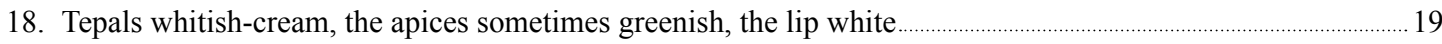

19. Apical trichomes conspicuous, c. $4 \mathrm{~mm}$ long .................................................................................

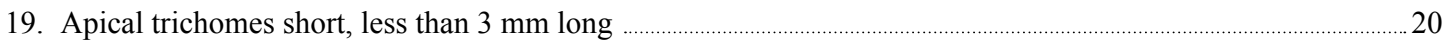

20. Callus large with fimbriate, very divided scales almost to their base; species from the Andaman Islands

20. Callus small, with lacerate scales; species from Indochina

V. andamanica

V. yersiniana

\section{KEY VII}

1. Ovary calyculate, penicillate callus absent, leaves shorter than the internodes of the stem

1. Ovary obscurely or not calyculate, penicillate callus well-defined, leaves usually longer than the internodes $\ldots 4$

2. Flowers tan-colored, the lip white and pink; flowers out-crossing, with slender, basally recurved pods V. bicolor 
2. Flowers concolorous, yellow, self-pollinated, with thick, strongly recurved about the middle, banana-like pods; plants from savannas, usually on palms

3. Lip less than $4.5 \mathrm{~cm}$ long; species from Cuba V. savannarum

3. Lip more than $5 \mathrm{~cm}$ long; species from South America V. palmarum

4. Lip strongly undulate-crispate, inflated-vernicose 5

4. Lip not strongly undulate-crispate, not conspicuously inflated nor vernicose …........................................................ 7

5. Inflorescences few-flowered, about 5-flowered; lip glabrous above callus ....................................................... 6

5. Inflorescences multiflorous, more than 10-flowered; lip covered with long trichomes ........................... V. espondae

6. Flowers large; lip more than $8 \mathrm{~cm}$ long V. trigonocarpa

6. Flowers small, lip less than $6 \mathrm{~cm}$ long V. sprucei

7. Flowers with white to greenish tepals, the lip usually white to greenish, the throat usually lined, the lip may be suffused with yellow, orange or brown on a white-green basal color, distal part of the lip often with papillae or retrorse trichomes, if smooth the flowers not conspicuously yellow

7. Flowers greenish-yellow, cream-yellow to yellow with the lip bright yellow to orange, without lines on the lip throat, distal half of the lip lacking papillae or trichomes apart from the penicillate callus

8. Leaves narrowly lanceolate to ensiform; lip distal part somewhat warty, with the margins erose, denticulate or fimbriate

8. Leaves ovate-lanceolate, oblong to elliptic, not narrowly lanceolate to ensiform, distal part of the lip smooth, warty or papillose, the margins rarely erose-fimbriate

9. Flowers small; lip 25-30 mm long; species from the Guyanas

9. Flowers large; lip 35-45 mm long; species widespread in the

10. Distal part of the lip smooth, except for the penicillate callus, occasionally the axial keels of the lip slightly prominent

10. Lip with warts, small papillae or conspicuous, retrorse trichomes on distal part

11. Flowers small, white to greenish-white; lip less than $35 \mathrm{~mm}$ long; leaves short, up to $4 \times 2 \mathrm{~cm}$, much shorter than the internodes; stems less than $5 \mathrm{~mm}$ thick

11. Flowers large, greenish cream; lip more than $60 \mathrm{~mm}$ long; leaves medium-size, more than $8 \times 3 \mathrm{~cm}$, slightly shorter than the internodes; stems stout, more than $7 \mathrm{~mm}$ thick

12. Midlobe of the lip defined, lip about $65 \times 30 \mathrm{~mm}$ when flattened; species from Brazil V. bahiana

12. Midlobe of the lip obscure, lip more than $80 \times 40 \mathrm{~mm}$ when flattened; species from the Caribbean Basin

V. phaeantha

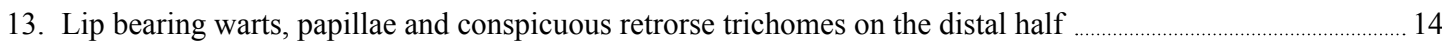

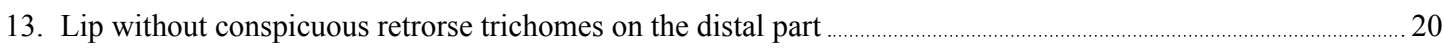

14. Lip subentire, distal half of the lip completely covered by trichomes ………………………........... V. ribeiroi

14. Lip trilobed $\ldots$

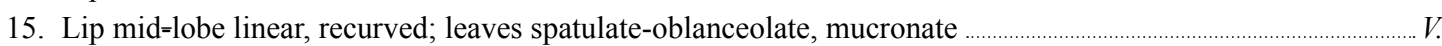
appendiculata

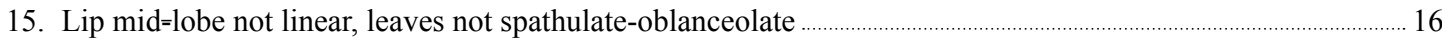

16. Trichomes confined to the axial zone of the distal half of the lip ................................................................................ 17

16. Trichomes covering all the surface of the distal half of the lip, although they may be longer axially ….............. 19

17. Trichomes from the penicillate callus to near the base of the midlobe ............................................................ V. dungsii

17. Trichomes from the penicillate callus to almost the lip apex .................................................................................... 18

18. Leaves 6 times as long as broad, tapering at base into an obscure petiole; lip midlobe much longer than the side lobes, acute

V. dubia

18. Leaves about 3.5 times as long as broad, abruptly constricted at the base into a distinct petiole; lip oblongobovate, mid=lobe emarginated 
19. Flowers very large; lip more than $8 \mathrm{~cm}$ long; stem conspicuously grooved and minutely papillose; leaves oblong V. insignis

19. Flowers not very large; lip less than $6 \mathrm{~cm}$ long; stem terete, smooth; leaves elliptic V. helleri

20. Leaves elliptic; species from Brazil V. schwackeana

20. Leaves oblong-elliptic; species from Central America (but escaped in all tropical areas) 21

21. Leaves oblong, about four times as long as broad V. planifolia

21. Leaves lanceolate, about six times as long as broad V. tahitiensis

22. Stems more than $8 \mathrm{~mm}$ thick; leaves succulent; basal bracts of the inflorescence not conspicuously distichous; lip with a thickened axial cushion near the lip apex, the veins of the distal part of the lip not thickened .......... 23

22. Stems less than $8 \mathrm{~mm}$ thick, leaves coriaceous, not conspicuously succulent, basal bracts of the inflorescence conspicuously distichous, lip without a thickened axial cushion near the lip apex, the veins of the distal part of the lip thickened 28

23. Lip conspicuously longer than the petals, the midlobe of the lip strongly emarginated ……............................ 24

23. Lip about as long as the tepals, the midlobe rounded to slightly notched 25

24. Tepals flared, ovary rather calyculate; species from Central America and NW South America .......... V. calyculata

24. Tepals not flared, rather concave, species from SE South America …........................................... V. chamissonis

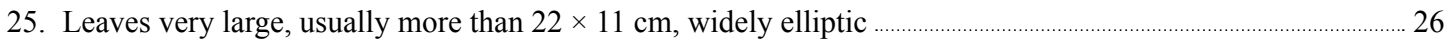

25. Leaves medium-sized, less than $16 \times 7 \mathrm{~cm}$, oblong to oblong elliptic 27

26. Midlobe of the lip well-defined V. pompona

26. Midlobe of the lip obscure V. grandiflora

27. Lip strongly concave V. pseudopompona

27. Lip gently concave V. columbiana

28. Lip entire; sepals not conspicuously papillose, the papillae, if present, scattered 29

28. Lip obscurely 3-lobed; ovary, sepals and dorsal keel of the petals conspicuously granulose in the outer surface 30

29. Lip acute to subacute; leaves oblong, not acuminate V. gardneri

29. Lip apex widely rounded; leaves oblanceolate, acuminate-cuspidate V. dressleri

30. Inflorescence many-flowered, up to 60 -flowered; leaves up to $26 \times 8 \mathrm{~cm}$; lip mid=lobe broadly ovate, with c. 10 thickened keels in the lip apex extending to the lateral lobes; species from Amazonia and Guyanas .... V. hostmanii

30. Inflorescence with less than 15 flowers; leaves less than $18 \times 7 \mathrm{~cm}$ 31

31. Mid-tobe of the lip subquadrate-ovate, with 5-6 thickened keels on the apical, central part of the lip, not extending to the lateral lobes, axial keel low; sepals rounded, slightly subcalyptrate; species from Central America ....V. cribbiana

31. Mid=lobe of the lip ovate, with c. 8 thickened keels, rather warty on the apical part of the lip, extending to the lateral lobes, 1-3 elevated, axial keels; sepals acute and conspicuously calyptrate; species from Peru and Bolivia V. weberbaueriana

\section{SYNOPSIS OF VANILLA}

Listed species, recognized as valid appear in bold face. Those described in Vanilla and considered to be synonyms are italicised.

Vanilla Plum. ex Mill., Gard. Dict. abridged de. 4, 3: without page number (1754). Lectotype: Epidendrum vanilla $L .=$ Vanilla mexicana Mill. (Mansf. in Kulturpfl. 2: 587, 1959)

Myrobroma Salisb., Parad. Lond. t. 82 (1807).

Vanillophorum Neck., Elem. Bot. 3: 184 (1790), nom. inval.
1. V. abundiflora J.J. Sm. in Bull. Jard. Bot. Buitenzorg ser. 3, 2: 21 (1920). Types: Borneo, Koetei, Soengei Djongkang, Tengaroeng, March 1918, W.C. van Gelder 1; Soengei Landak, J.E. Teysmann s.n.; Kapoeas, J.E. Teysmann 109898 (all syn. BO).

Distribution: Borneo (Kalimantan Timur, Sarawak).

Similar to $V$. kinabaluensis because of its long inflorescences with more than 100 successive flowers and large leaves, but $V$. abundiflora has smaller flowers, and the apical hairs of the lip are less conspicuous. 
It has branched trichomes on the column below the stigma. Carr 3417 was misidentified as V. sumatrana, a plant apparently related to $V$. griffithii.

Collections. SARAWAK: Yii Puan Ching S.61441 (K!); SABAH: Koung, Carr 3417 (K!).

SourCES: Smith, J.J. 1920. Bull. Jard. Bot. Buiten. 2: t. 6; Portères, R. 1954. Le Genre Vanilla et ses Espèces: 213-214, fig. 99.

2. V. acuminata Rolfe in J. Linn. Soc. Bot. 32: 456 (1896). Type: Gabón, Munda Prov., Soyaux 134 (holo. $\mathrm{K} !)$.

\section{Distribution: Gabon, Congo.}

This species is very close to $V$. africana and stout plants of it are indistinguishable. The lip is said to have an oblong, obtuse, apiculate mid-lobe, and the disc bears a smaller callus with only about three scales. The lip is missing in the type specimen.

Sources: Portères, R. 1954. Le Genre Vanilla et ses Espèces: 201, fig. 94.

\section{$V$. acuta Rolfe $=V \cdot$ guianensis}

V. acutifolia Lodd. ex W.Baxt. in Suppl. Hort. Brit. 3: 655 (1850). nomen (Venezuela)

3. V. africana Lindl. in J. Linn. Soc. Bot. 6: 137 (1862). Types: Upper Guinea, Brass R., Barter 47 (syn. K-LINDL! isosyn. K!); Hort. Loddiges (K-LINDL! watercolor only).

Distribution: Guinea, Liberia, Ivory Coast, Ghana, Nigeria, Cameroon, Gabon.

Among the African complex, $V$. africana is characterized by its oblong-lanceolate, long acuminate leaves, the triangular, broadly rounded side lobes of lip, and the ovate midlobe. It is not always easy to distinguish from poorly flowered localities specimens of $V$. ramosa.

Collections: EQUATORIAL GUINEA: Mann s.n. (K!); W.W. Sanford 6032 (K!); Whyte (K!). GABON: Griffon de Bellay 501125 (W!); van der Burg 6691 (K!). CAMEROUN: Braun s.n. (K!). NIGERIA: Richards 3251 (BM!); Hort. Rotterdam Bot. Gard. (K!). GHANA: Johnson 798 (K!); Johnson 859 (K!); Bowling 36605 (K!). IVORY COAST: Hepper \& Maley 8196 (K!); Pérez-Vera 561 (K!). LIBERIA: Adam 20267 (K!). WITHOUT LOCALITY: Hort Schiller (W!).
SourCEs: Portères, R. 1954. Le Genre Vanilla et ses Espèces: 203-206, fig. 95 (apparently mixed with $V$. ramosa); Summerhayes, V.S. 1968. Flora of West Tropical Africa 3(1): Orchidaceae: 205; Szlachetko, D.L. \& Olszewski, S. 1999. Fl. de Cameroun: 284, pl. 100, A-F.

4. V. albida Blume, Catalogus 100 (1823). Type: Java, Gunong Salak, Parang, Burungrang, Blume s.n. (holo. L).

Distribution: Indonesia (Java and Sumatra).

We interpret this species as the plant illustrated by Comber (1990) in Orchids of Java. It has flowers with green tepals and a large, deflexed, white lip with conspicuous trichomes at the lip apex. Vanilla albida is similar to $V$. montana and $V$. yersiniana, and they have been submerged in the synonymy of the former by some authors. However, V. montana has larger trichomes at the lip apex, broader leaves, and V. yersiniana has shorter trichomes and whiter tepals, longer sepals and shorter lip. The plant illustrated by Comber (1990) was collected on Gunong Hambali, Lenkong, SW Java, not far from Blume's original locality. Comber (pers. comm.) indicated that the sepals become yellower with age. Blume's plate 67 shows a flower also with greenish tepals, similar to Comber's plant rather than to the Thailand plants identified as $V$. albida in recent years that must treated as $V$. yersiniana.

Collections: INDONESIA, JAVA: Blume's Rumphia t.67!; Zollinger 961 (W!); C. Doran (K!); cult. Bogor s.n. (K! W!); Horsfield (BM!); Curtis 2271 (BM!).

SourCes: Blume, C. 1825. Bijdr. 422; Portères, R. 1954. Le Genre Vanilla et ses Espèces: 208-209, fig. 97.

\section{V. anaromatica Griseb. $=\boldsymbol{V}$. mexicana}

5. $\boldsymbol{V}$. andamanica Rolfe in Bull. Misc. Inform. Kew 1918: 237 (1918). Type: Andaman Islands, Betapur Valley, 25 Feb. 1916, C.E. Parkinson 1139 (holo. K!).

Distribution: India: Andaman Islands only.

Often relegated to the synonymy of $V$. albida to which is closely related. However, it has a larger penicillate callus in which the scales are so divided, that they look more like hairs than scales. This, together with its isolated distribution in Andaman Islands, suggest that is better considered as a distinct species. 
Source: Portères, R. 1954. Le Genre Vanilla et ses Espèces: 220.

V. angustifolia Willd., Sp. Pl. 4: 121. (1805).

6. V. angustipetala Schltr. in Anex. Mem. Inst. Butantan Secc. Bot. 1(4): 19 (1922). Type: Brazil, Sao Paulo, near Morro das Pedras, Iguapé, Dec. 1916, A.C. Brade 7775 (holo. RJ; iso. AMES 114509! K!, R!).

V. rojasiana Hoehne in Arq. Bot. Estado Sao Paulo n.s. 1: 61. t. 82 (1941). Type. Paraguay, Estancia Princeza, Caguazu, , cult. Asunción, April-May 1927, T. Rojas 5082 \& 5082-A (syn. RJ; isosyn. AMES 58883! sterile).

Distribution: S Brazil, Paraguay and Argentina.

We have examinated the type of $V$. angustipetala and it matches well the published drawings of $V$. rojasiana. This species seems to be close to $V$. parvifolia, based on Rodrigues's original plate, which has broader, shorter petals, a more definitively 3-lobed lip, and it lacks the papillae on the disc of the lip, and to $V$. verrucosa, and perhaps not specifically different from them.

Collection: PARAGUAY: E. Hassler 1294 (K!).

Source: Portères, R. 1954. Le Genre Vanilla et ses Espèces: 174-176, fig. 84.

7. V. annamica Gagnep. in Bull. Mus. Natl. Hist. Nat. sér. 2, 3: 686 (1931). Types: Vietnam, Annam, col de Mangiang, Qui-nhon Prov., Poilane 17973 (syn. P; isosyn K!); Lang-bian, between B'dle and Dankia, Poilane 18635 (syn. P; isosyn. AMES 65778!); Langbian, Jacquet 622 (syn. P); Bihn-thuan Prov., Djiring, Mangnein 82 (syn. P).

DistRIBUTION: S China and Vietnam.

This species was described from immature buds. However, the branched, cymose inflorescence, with two opposite flowers per cyme, and the large leaves are characteristic. Flowers structure of modern Vietnamese specimens are similar to those of $V$. somai, from Taiwan, with many flat papillae at the lip apex.

Collections: CHINA: Guizhou, Tzi, Luo, Cribb \& McGough ASBK 37 (K! PE!); Yunnan, Cavalerie 3427 (K!).

SourCES: Gagnepain, F. \& A. Guillaumin, A. 1932. Flore Genérale de L'Indo-Chine 2. Orchidacées: 584-585, fig. 56; Portères, R. 1954. Le Genre Vanilla et ses Espèces: 179-180, fig. 86; Averyanov, L. 1988. Predvaritelnyt spisok orkhidnykh: 110, fig. 6; Averyanov, L.V. 1994. Identification Guide to Vietnamese Orchids: 76.

V. anomala Ames \& L.O. Williams = Pseudovanilla anomala

8. V. aphylla Blume, Bijdr. Fl. Ned. Ind. 8: 422 (1825). Type: Java, near Sadjvam Province, Bantam; Nusa Kambanga islands, Nov.-March, Blume 1719 (holo. L) Limodorum aphyllum Roxb., Pl. Coromandel 1: 34, pl. 41 (1795).

Vanilla parishii Rchb. f., Otia Bot. Hamburg 1: 39 (1866). Type: Myanmar, Tanasserim, Parish 286 (holo. K!).

Distribution: Myanmar, Laos, Thailand, Vietnam, Malaysia, Indonesia (Java).

This is the commonest leafless Vanilla of SE Asia. The lip of the specimen of $V$. parishii at Kew bears scattered hairs on the side lobes of the lip, and it is not clear if this represents a distinct character or if, as proposed by Seidenfaden, they are pieces of veins that have broken due to much boiling. Vanilla aphylla is closely related to $V$. calopogon of Philippines and $V$. wightii of India.

Collections: THAiland: Kerr s.n. (K!); Kerr 0791 (K!); Haniff \& Nur 4391 (K!); Put 1907 (K!). VIETNAM: Pierre 6565 (K!). INDONESIA: Java, Zollinger 599 (G7888/100! 101! K-LINDL!)

Sources: Ridley, H.N. 1924. The Flora of the Malay Peninsula: 201; Gagnepain, F. \& A. Guillaumin. 1932. Flore Genérale de L'Indo-Chine 2. Orchidacées: 582; Averyanov, L. 1988. Predvaritelnyt spisok orkhidnykh: 110, 112; Seidenfaden, G. \& T. Smitinand 1959. The Orchids of Thailand: a preliminary list, part 1: 57, fig. 39; Seidenfaden, G. 1978. Orchid Genera in Thailand VI. Dansk Bot. Arkiv. 32(2): 142, 145-146, fig. 90; Averyanov, L.V. 1994. Identification Guide to Vietnamese Orchids: 77; Holttum, R.E. 1964. Flora of Malaya. Orchids: 98; Comber, J.B. 1990. Orchids of Java: 75.

V. aphylla Wight $=\boldsymbol{V}$ wightii

V. aphylla Eggers $=\boldsymbol{V}$. poiteai

9. V. appendiculata Rolfe in Bull. Misc. Inform. Kew 1895: 178 (1895). Type: Guyana (British Guiana), 
Corentyne River, im Thurn s.n. (holo. K!).

V. purusara Barb. Rodr. ex Hoehne, Arq. Bot. Estado- Sao Paulo, n.s. 1: 127. t. 140 (1944). Syntypes: Brazil, Amazonas, Bom-Lugar, Río Purús, May 1904, Huber s.n. (MG 4721!); Pará, Igapó edge of the Pirapitinga, tributary of the Jutaí de Almeirim, 19 April 1923, Ducke s.n. (RJ 18704!).

V. marowynensis Pulle, Enum. Vasc. Pl. Surinam: 118, pl. 4 (1906). Type: Surinam, Upper Marowyne River, near Poeloegoedoe, July, Versteeg 623 (not seen).

Distribution: Guyana, Surinam, Brazil and Peru.

$V$. appendiculata is distinguished by its large, spatulate, abruptly mucronate leaves, and large flowers with a narrow apical lobe to the lip, that is strongly reflexed and papillose-barbellate. Vanilla marowynensis seems to be conspecific, although the illustration, based on an immature bud is inadequate. This species seems to be common in Amazonia. Collections: BRAZIL, Amazonas: Cavalcante 659 (MG!); PERU, Loreto, Ruiz \& Murphy 255 (K!).

Source: Portères, R. 1954. Le Genre Vanilla et ses Espèces: 223 and 228, fig. 103 (as V. marowynensis).

$V$. argentina Hicken $=\boldsymbol{V}$. chamissonis

$V$. aromatica Willd. $=\boldsymbol{V}$. planifolia

$V$. aromatica $\mathrm{Sw} .=\boldsymbol{V}$. mexicana

V. articulata Northr. $=\boldsymbol{V}$. barbellata

10. V. bahiana Hoehne in Arq. Bot. Estado- SaoPaulo, n.s. 2, 5: 108, t. 43 (1950). Type: Brazil, Zona litorânea da Bahia, Nov. 1947, Ferreira Da Cunha s.n. (holo. SP 54661).

DistriBution: Known only from Brazil.

A xerophytic inhabitant of the coastal caatinga (or restinga), often with big flowers superficially resembling those of $V$. pompona, with the midlobe of the lip very short. Its closest relative seems to be $V$. phaeantha. Like $V$. phaeantha, the leaves are usually much shorter than the internodes. Some specimens listed as syntypes of $V$. gardneri actually belong to $V$. bahiana.

Collections: BRAZIL: BAHIA: Harley 17366 et al. (K!); de Queiroz, Mayo \& Nadruz 2918 (K!).
V. bakeri Schltr. $=$ See $\boldsymbol{V}$. barbellata .

\section{V. bampsiana Geerinck $=V$. planifolia}

11. V. barbellata Rchb. f. in Flora 48: 274 (1865). Type: Cuba, C. Wright 3352 (holo. W; iso. AMES 70985! K! US!).

V. articulata Northrop in Mem. Torrey Bot. Club12(1): 31, pl. 3 (1902). Types: Bahamas, New Providence, Feb., fl. July; London Creek, May; Deep Creek, June, Northrop 545 (syn. NY according to Correll, 1946).

V. bakeri Schltr. in Repert. Sp. Nov. Regni Veg. 8: 561 (1910). Type: Cuba, Cojimar, Havana Prov., June 1905, F.C. Baker 5127 (holo. B†); same locality and date, Baker 5127 (lectotype here designated HAC!).

Distribution: Florida, Bahamas, Cuba, Dominican Republic, Puerto Rico, Virgin Islands.

Vanilla barbellata is one of the commonest species in the Caribbean Islands and Florida. It is distinguished by its relatively small flowers and conspicuously 3-lobed, truncate lip.

The holotype of V. bakeri was destroyed at B; the only duplicate of it is housed at HAC, but it has only fruits. The original description of the flower suggests that it may have been based in an immature bud of $V$. barbellata, but details of the lip ornamentation do not coincide with the morphology of that species. The lectotype, although sterile, corresponds with the morphology of $V$. barbellata, the fruits being smaller those of $V$. dilloniana. Its flowering season also corresponds to that of $V$. barbellata and there is also an additional collection of $V$. barbellata from the same locality (León 6278 HAC!).

Collections: Wright 3337 (BM!). CUBA: L.B. Smith et al. 3041 (AMES!); cf. N.L. Britton, F.S. Earle \& P. Wilson 4592 (AMES!). BAHAMAS: N.L. Britton \& L.J.K. Brace 540 (K!); D. Morris s.n. (K!); N.H. Nickerson, D. Sammons \& B. Kessler 2755 (AMES!); N.H. \& W.L. Nickerson 2826 (AMES!); L. Zemaitis \& N.H. Nickerson s.n. (AMES!). DOMINICAN REPUBLIC: A. Liogier 11610 (AMES!) \& 15640 (AMES!). WITHOUT LOCALITY: cf. Pavón (actually Sessé and Mociño) 20-1 (G7889/179!); Mociño 112 (watercolor!).

Sources: Britton, N.L. \& C.F. Millspaugh, 1962. The 
Bahama Flora: 84 (as V. articulata); Acuña, G.J. 1939. Catálogo Descritivo de las Orquídeas Cubanas: 21-22 (as V. articulata); León, F.S.C. \& F.S.C. Alain-1946. Flora de Cuba 1: 351 (as V. articulata); Hawkes, A.D. 1948. Notes on Vanilla barbellata. Amer. Orchid Soc. Bull. 17(11): 652-653; Correll, D.S. 1946. The American species of "leafless" Vanillas. Amer. Orchid Soc. 15(7): 328-332. Luer, C. 1972. Native Orchids of Florida: 76, pl. 20; Ackerman. J.D. 1995. An Orchid Flora of Puerto Rico and the Virgin Islands: 171-174, fig. 94.

\section{V. barrereana Veyret $\&$ Szlach. $=V$. hostmanii}

V. beauchenei A. Chev., Etudes Fl. Afr. Centr. Franc. 1.297 (1913), nomen.

12. V. bertoniensis Bertoni in An. Ci. Parag. ser. I, 8: 10 (1910). Type: Paraguay, Puerto Bertoni, Bertoni 6039 (holo. not located).

Distribution: Paraguay.

A scarcely known plant, described as larger than $V$. perexilis $(=V$. parvifolia $)$, with contorted sepals and a lip with a triangular acuminate midlobe. However, the ovary was described as calyculate, a trait unknown in other members of this group. We suspect that this may be the earliest name for the plant currently known as V. edwallii.

Source: Portères, R. 1954. Le Genre Vanilla et ses Espèces: 262-264.

13. V. bicolor Lindl. in Edward's Bot. Reg. 24: Misc. 58 (1838). Type: Guyana (British Guiana), Schomburgk s.n. (K-LINDL, not traced); lectotype (designated by Christenson, 1995) Guyana, Demerara, watercolor illn. by Schomburk s.n. ex Hort. Loddiges (K-LINDL!).

V. claviculata sensu Lindl. in Ann. and Mag. Hist., ser. 3, 1: 334 (1858), non Sw.

V. wrightii Rchb. f., Flora 48: 273 (1865). Type: E Cuba, 1856-7, Wright 672 (holo. W! iso. AMES 70991 ! \& 70986! (the last apparently with a flower of $V$. cf. barbellata) BM! G7889/135! K! $\mathrm{MO}$ ! P!).

V. gratiosa Griseb., Cat. Pl. Cub. 267 (1866). Type: Based on same type as $V$. wrightii Rchb.f.

V. palmarum sensu Grisebach, Cat. Pl. Cub. 267 (1866), non (Salzmann ex Lindl.) Lindl.
Distribution: Cuba, Jamaica, Hispaniola, Venezuela, Guyana, Surinam, French Guyana, Trinidad, and Brazil.

A very distinct Caribbean and Guyanan species. The slender plants with small, elliptic leaves, which are much shorter than the internodes, elongate inflorescences, a calyculate ovary, basally recurved pods, tan-colored tepals, a cream-yellowish lip with scattered hairs on the disc, and a poorly penicillate callus are characteristic among American vanillas. It differs from other Vanilla species, in that several populations are found in mountain habitats up to 1700 $\mathrm{m}$ elevation. Molecular data suggest that it is the sister species of all the American penicillate vanillas.

This species is widely known as $V$. wrightii, a synonym; however, its identity was first elucidated by Sarah Thomas, from Kew and Eric Christenson published a well illustrated paper on the correct identity of this species.

Collections: VENEZUELA: J.A. Steyermark, G.C.K. \& E. Dunsterville 92177 (AMES!); B. Maguire 32967 (AMES!); B. Maguire \& L. Politi 28258 (AMES!). BRAZIL: Roraima: J.B.F. da Silva 263 (MG!); Amazonas: B.G.S. Ribeiro 1028 (MG!); ?col. 7885 (BM!). GUYANA: G.S. Jenman 803 \& 4561 (K!); E.F. im Thurn 43 (K!); B. Maguire \& D.B. Fanshawe 23176 (K!); N.Y. Sandwith 1331 (K!); S.S. \& C.L. Tillett, R. Boyan 44880 (K!). SURINAM: Hostmann s.n. (K!); B. Maguire 24258 (K!). JAMAICA: $H$. Wood (BM! drawing); [?Langley] 7885 (BM!). DOMINICAN REPUBLIC: B. A.H. Liogier 11474 \& 11742 (AMES!); W.L. Talbot 2363 (AMES!). HAITI: E.L. Ekman 4355 (AMES! K!). CUBA: Eggers 5248 (K!); J.A. Schafer 3218 \& 4047 (AMES!); B. Clemente 1956 \& 6626 (AMES!); B. Alain 373 (AMES!); C.V. Morton \& J. Acuña 3527 (AMES!); F. León, F. Clement, F. M. Roca 9992 (AMES!(; B. León 15646 (AMES!).

Sources: Portères, R. 1954. Le Genre Vanilla et ses Espèces: 222 and 259-260 (as V. wrightii); Christenson, E.A. 1995. The long-lost Vanilla bicolor. Amer. Orch. Soc. Bull.: 64(8): 844-847; Schultes, R.E. 1960. Native Orchids of Trinidad and Tobago: 44 (as V. wrightii); Foldats, E. 1969. Flora de Venezuela. Orchidaceae 1: 127-129 (as V. wrightii); Gloudon, A. \& C. Tobisch. 1995. Orchids of Jamaica: 209 (as $V$. wrightii); Acuña, G.J. 1939. Catálogo Descritivo de 
las Orquídeas Cubanas: 22-23 (as V. wrightii); León, F.S.C. \& F.S.C. Alain. 1946. Flora de Cuba I: 352 (as V. wrightii); Martius, F.P., Fl. Brasiliensis 3: t. 4: 149. 1896.

14. V. borneensis Rolfe in J. Linn. Soc. Bot. 32. 460 (1896). Type: Kalimantan, Banjarmassing, Motley 1248 (holo. K!).

V. pilifera Holtttum in Gard. Bull. Singapore 13: 251-253 (1951). Type: Malaysia: Kota Tingii, Johore, le Doux s.n. (holo. SING).

Distribution: Reported from NE India, Thailand, Malaysia and Indonesia (Kalimantan).

This species was described from a fruiting specimen, and its flowers are unknown. No additional specimens are known from southern Kalimantan, where the species was originally collected. The elliptic-oblong, long acuminate leaves are different from other Bornean vanillas, such as V. griffithii. The few-flowered racemes separate it from the densely flowered racemes of $V$. havilandii (or the Javanese $V$. albida), or the long, many-flowered racemes of $V$. abundiflora and $V$. kinabaluensis. However, it looks very similar to specimens of $V$. pilifera collected in Sabah, northern Borneo, especially in leaf shape and the few-flowered, rather zigzag rachis of the inflorescence. Thai specimens of $V$. pilifera have much narrower, lanceolate, acute leaves, and shorter inflorescences. V. montana, from peninsular Malaysia, has oblanceolate, abruptly acuminate leaves that are also similar.

It is easily distinguished by its lanceolate to elliptic, often narrow, short leaves and conspicuously hirsute disc of lip. It is closely related to $V$. diabolica, from Sulawesi.

A Burbidge specimen (Burbidge s.n., BM) from Sabah, NW Borneo (Tawaran and Tampasuk rivers), may belong to $V$. kinabaluensis, rather than to $V$. borneensis, as suggested by Rolfe.

Collections: THAILAND: Put 2285 (BK C K!). MALAYSIA: SABAH: A. Lamb 87/83 (K! specimen and drawing); Daim Andau 440 (K! sterile); SAN 122464 (K! sterile); SAN 68739 (K! sterile); A. Talip 54914 (K! sterile); J. Beaman 7804 (K! sterile); L. Madani SAN 89511 (K! sterile).

Sources: Portères, R. 1954. Le Genre Vanilla et ses Espèces: 215-216; Portères, R. 1954. Le Genre Vanilla et ses Espèces: 169-170 (as V. pilifera); Teo, C.K.H. 1985. Native Orchids of Peninsular Malaysia: 108109 (photo. of V. aphylla?; as V. pilifera); Seidenfaden, G. \& T. Smitinand 1959. The Orchids of Thailand: a preliminary list, part 1: 57, fig. 39 (in part; the illustration based on TS 4075, may be V. yersiniana??; as V. pilifera); Seidenfaden, G. 1978. Orchid Genera in Thailand VI. Dansk Bot. Arkiv. 32(2): 142-143, fig. 88 (as V. pilifera); Seidenfaden G. \& J.J. Wood. 1992. Orchids of Penninsular Malaysia and Singapore 125 (as V. pilifera). Holttum, R.E. 1964. Flora of Malaya. Orchids: 95-96, fig. 16A (as V. pilifera).

15. V. bradei Schltr. ex Mansf in Repert. Sp. Nov. Regni Veg. 24: 243 (1928). Type: Brazil, Sao Paulo, A.C. Brade 7573 (holo. $\mathrm{B} \dagger$, AMES drawing!).

SourCEs: Portères, R. 1954. Le Genre Vanilla et ses Espèces: 258-259.

16. V. calopogon Rchb. f., Otia Bot. Hamburg. 1: 40 (1878). Type: Philippines, Luzón, Cuming 2070, 1841 (holo. W!; iso. BM! G7889/99 168! K-LINDL! K!).

Distribution: The Philippines (Luzón).

This species is very closely related to $V$. aphylla and $V$. wightiana. However, it has slightly larger flowers and is endemic to Luzón.

Collections: LUZON: Loher 630 (K!).

Source: Valmayor, H.L. 1984. Orchidiana Philippiniana 1: 322 .

17. V. calyculata Schltr. in Repert. Sp. Nov. Regni Veg. 7: 42 (1920). Type: Colombia, M. Madero s.n. (holo. $\mathrm{B} \dagger$ ).

Distribution: Honduras, El Salvador and Colombia.

The status of $V$. calyculata remains uncertain and no original material has been located. However, the description suggests that the name must be applied to the specimens listed below. Its calyculate ovary, long emarginate midlobe of the lip, small leaves and the relatively high elevation of its habitat are characteristic. This species is closely related to $V$. chamissonis from Brazil. Specimens from El Salvador have been misidentified as V. phaeantha (Hamer, 1974).

Collections: EL SALVADOR: Pank in Hamer 203 (AMES!). HONDURAS: Comayagua, Yuncker et al. 6045 (AMES! G78889/152! K!). COLOMBIA: 
Valle, Dryander 2379 (BM!); Tolima, Lehmann 2263 (BM! G7889/175!); Lehmann 8378 (K! watercolor); La Plata, cf. Lehmann 6278 (AMES!).

SourCEs: Portères, R. 1954. Le Genre Vanilla et ses Espèces: 247. Hamer, F. 1974. Las Orquídeas de El Salvador 2: 375, t. 41 (as V. phaeantha)

$V$. carinata Rolfe $=$ see in excluded species

18. V. chalotii Finet in Bull. Soc. Bot. France, 56: 102 (1909). Type: Gabon, near Libreville, Chalot 4027 (holo. P).

Distribution: Endemic to Gabon.

This species has a conspicuous, shallowly saccate lip, with a very reduced, recurved, apical lobe. It is similar to $V$. nigerica and $V$. seretii, in which the stems are verrucose, and the white and pink flowers are much larger.

Sources: Portères, R. 1954. Le Genre Vanilla et ses Espèces: 170-171, fig. 82; Szlachetko, D.L. \& S. Olszewski. 1999. Fl. de Cameroun: 280-282, pl. 100, A-F.

19. V. chamissonis Klotzsch in Bot. Zeitung 4: 564 (1846). Type: Brazil, Chamisso s.n. (lecto. LE! photo).

Distribution: Brazil.

Two different taxa have been called $V$. chamissonis in recent times. The true $V$. chamissonis has a very long midlobe of the lip (e.g. drawings of Portères, 1954, fig. 104; Martius, 1986, t. 32 or Hoehne's illustration of $V$. chamissonis var. longifolia); the other one is $V$. vellozii, reduced by most recent authors to a variety of the former. Vanilla chamissonis is similar to the $V$. calyculata from Colombia and Central America. Vanilla vellozii is different in its shorter segments and subentire lip, and it is not clear if it is a member of the $V$. chamissonis or $V$. pompona complexes.

Collections: BRAZIL: Glaziou 15661 (K!); The specimen Glaziou 14302, "Environs of Rio Janeiro", was assigned by Rolfe (1896) to V. vellozii, but, although with very bad preserved flowers, it seems to have the very long lip characteristic of $V$. chamissonis; a similar case occurs with the Glaziou specimen from Copacabana (apparently that considered by Rolfe to be his number 11621). Goias, cf. A. Glaziou 22151 (G 7889/115!). BAHIA: M. Blanchet s.n. (G 7889/114)!; Dusén s.n. (AMES 86539!). Rio de Janeiro, Miers (BM!); L.A. Gattoni s.n. (AMES 66126! AMES
66339! AMES 66345!).

Sources: Martius, F.P., Fl. Brasiliensis 3: pt. 4: 148, t. 32. 1896; Portères, R. 1954. Le Genre Vanilla et ses Espèces: 190, fig. 90 (as ?V. vellozii), p. 191-192 (as V. argentina); Pabst, G.F.J. 1966. As- Orquídeas do Estado da Guanabara. Orquídea 28(2-6): 169-170.

20. V. claviculata (W.Wright) Sw. in Nov. Act. Soc. Sc. Upsal. 6: 66 (1799). Type: Jamaica, Swartz s.n. (lecto. BM!, here designated).

Epidendrum claviculatum W. Wright in London Med. J. 8(3): 254 (1787).

Distribution: Cuba, Jamaica, Hispaniola, Grand Cayman, Puerto Rico, St. Thomas.

It belongs to the American leafless group but can bear fugaceous, small leaves, up to $8 \times 1 \mathrm{~cm}$, which are conspicuosly apiculate. The lip is not conspicuously trilobed at apex, as its allies, but rather rounded, and it has a penicillate callus of dense forked hairs and rows of similar hairs towards the apex, but not dense.

Collections: CUBA: León \& Alain 19346 (AMES!); R.A. Howard 6522 (AMES!); A.H. Liogier 11493 (AMES!); R.M. Gray s.n. (AMES! K!). DOMINICAN REPUBLIC: R.A. \& E.S. Howard 8654 (AMES!). PUERTO RICO: A.G. Kevorkian s.n. (AMES!). JAMAICA: H. Wood (BM! drawing); C. Whitefoord 1423 (BM!). GRAND CAYMAN: M. Brunt 2186 (BM!); W. Kings G.C. 412 (BM!).

Sources: Sloane, H. 1725. Jamaica Nat. Hort. t. 224; Fawcett, W. \& A.B. Rendle. 1910. Flora of Jamaica 1. Orchidaceae 16-17, pl. 2: 18-19; Acuña, G.J. 1939. Catálogo Descriptivo de las Orquídeas Cubanas: 23 (as V. parasitica); Correll, D.S. 1946. The American species of "leafless" Vanillas. Amer. Orchid Soc. Bull. 15(7): 328-332; León, F.S.C. \& F.S.C. Alain. 1946. Flora de Cuba 1: 352, 354; Gloudon, A. \& C. Tobisch. 1995. Orchids of Jamaica.: 206-207; Castillo Mayda, M. \& J.D. Ackerman. 1992. The Orchids of Puerto Rico and the Virgin Islands: 52, pl. 10; Ackerman. J.D. 1995. An Orchid Flora of Puerto Rico and the Virgin Islands: 174, fig. 95.

V. claviculata sensu Lindl. in Mem. Am. Acad. n.s. 8: $219(1861)=\boldsymbol{V}$. bicolor

21. V. columbiana Rolfe in J. Linn. Soc. Bot. 32: 468 (1896). Type: Colombia [New Granada], Valley of the Magdalena, February, Goudot s.n. (holo. K!). 
The type material is very unsatisfactory, making an accurate description of this species problematic. The dissected flower of the type, probably an immature bud, has a very neat midlobe to the lip. We have assigned to this concept specimens from the $V$. pompona complex with small leaves, resembling those of $V$. phaeantha, with flowers with green sepals and petals and a white lip with a yellow edge, but we would like to examine more material from the Magdalena Valley. It is possible that they might better be attributed to the plant we are treating here as V. calyculata.

Collections: COLOMBIA: F.A. Barkley \& $M$. Valderama 35275 (AMES!); H. Garcia-Barriga 15373 (AMES!); J.L. Zarucchi \& C. E. Barbosa 3637 (AMES! MO).

Source: Portères, R. 1954. Le Genre Vanilla et ses Espèces: 229-231, fig. 103.

\section{V. correllii Sauleda \& R.M. Adams $=\boldsymbol{V}$. poitaei}

\section{V. costaricensis Soto Arenas ined.}

Distribution: Endemic to Costa Rica.

This new species of Vanilla is closely related to $V$. mexicana, from the West Indies and NE South America. However, V. costaricensis has a very short midlobe to the lip and large bracts similar to those of $V$. inodora Schiede. The species was illustrated by Rafael Lucas Rodríguez (1986), but apart from this record, it is known only from the type and another collection from the same locality. As far as is known, V. mexicana is not found in Central America.

Sources: Lucas Rodríguez, R., D.E. Morta, M.E. Barahona \& N.H. Williams. 1986. Géneros de Orquídeas de Costa Rica: 70-71.

23. V. coursii H. Perrier in Rev. Int. Bot. Appl. Agric. Trop. 30: 435 (1950). Type: Madagascar, N of Antalaha, Cours G6 (holo. P!)

Distribution: Endemic to Madagascar.

Very poorly known. We have been unable to examine material of this leafy Madagascan species, and from the literature it is difficult to suggest its affinities, the presence of leaves, the hexagonal lip and the very small flowers are different from other species of the island.

Sources: Portères, R. 1954. Le Genre Vanilla et ses Espèces: 170; DuPuy, D., P. Cribb, J. Bosser \& J. \& C. Hermans:1999. The Orchids of Madagascar: 207.
24. V. crenulata Rolfe in J. Linn. Soc. Bot. 32: 477 (1896). Types: Sierra Leone, Bumban to Lokko, Scott Elliot 5733 (syn. K!; isosyn. BM!); Ashanti, Prahsu, Cummins 4 (syn. K!).

Distribution: W and WC Tropical Africa.

Another member of the $V$. africana complex, often considered as conspecific with $V$. ramosa. It is characterized by its broad leaves, unbranched inflorescence, and flowers with a broader and less acute crenulate front lobe of the lip. Characteristic is the presence of very broad, oval bracts at the base of the raceme. Summerhayes (1968) also indicated a larger lip, midlobe and column in $V$. crenulata, compared with $V$. ramosa.

In living condition, $V$. crenulata flowers are easily distinguished by their conduplicate, gibbose mid= lobe of the lip, with a penicillate callus at the top of the gibba. In their relatives (e.g. V. ramosa) the lip is rather flat, but this character is difficult to see in herbarium specimens. Szlachetko \& Olszewski (1999) considered $V$. crenulata to be a synonym of $V$. africana. Collections: GUINEA: Schnell 3086, 799 (K!). LIBERIA Bunting s.n. (BM!); Barker 1265 (K!); Jansen 1013 (K!); Baldwin 10661A, 10966, 11116 (K!); Whyte s.n. (K!); Blickenstaff 92 (K!); Linder 46, 76 (K!). GHANA: Fishlock 57 (BM! K!); Wilson 1036 (K!); Bowling 38137 (K!); Westwood 112 (K!); Irvine 1186, 1808 (K!); Vigne 3062 (K!); Darko 1018 (K!); Morton GC6553 (K!). IVORY COAST: PérezVera 642 (K!); de Wilde 576 (K!); Chevalier B22383 (K!); Leeuwenberg 3054 (K!). NIGERIA: Miles s.n. (BM!). GABON: Le Testu 1413 (BM!); van der Laan 834 (K!). SIERRA LEONE: Deighton 2496, 2963, 6151 (K!); Dawe 439 (K!); Bobob s.n. (K 37879!); Segerbäck 1537 (K! also photos); Thomas 3432 (K!). PRINCIPE: Exell 623 (BM!). ZAIRE: Lebrun 3241 (K!). WITHOUT LOCALITY: Johnson 24 (K!).

Sources: Portères, R. 1954. Le Genre Vanilla et ses Espèces: 196-198, fig. 92; Geerinck, D. 1984. Flore D'Afrique Centrale (Zaire, Rwanda-Burundi): 239242; Summerhayes, V.S. 1968. Flora of West Tropical Africa 3(1): Orchidaceae: 205-206. Johansson, D. 1974. Acta Phytogeographica Suecica 59: 44-45.

\section{V. cribbiana Soto Arenas, ined.}

Distribution: Known from Mexico (Veracruz, Oaxaca, Chiapas), Guatemala, Belize, and Honduras. 
Vanilla cribbiana is a member of the $V$. hostmanii group. Its fruits are fragrant, and probably of some interest, but the vine is not a strong grower and does not produce fruits regularly.

Collections: BELIZE: C. Whitefoord 1816 (BM!). HONDURAS: $O$. Ames II-211 (AMES!).

26. V. cristagallii Hoehne in Arq. Bot. Estado- SaoPaulo, n.s. 1: 125 (1944). Type: Brazil, Amazonas, Sao Paulo de Olivença, 23 Oct. 1931, Ducke s.n. (holo. RJ 14512!).

V. cristato-callosa Hoehne in Arq. Bot. EstadoSao- Paulo- ns.s. 1: 126. t. 137 (1944). Type: Brazil, Amazonas, Manáus, 20 Oct. 1935, Ducke s.n. (holo. RJ 37468!).

Distribution: Amazonian Brazil.

This species, like several other Amazonian species, has an apical lobe adorned with retrorse trichomes or transverse crests. The difference between the types of $V$. cristagalli and $V$. cristato-callosa is mostly in the size of the flowers and lip, but they seem to represent the same species.

Source: Hoehne, F.C. 1944. Arq. Bot. Estado SaoPaulo, n.s. 1: 125.

27. V. cucullata Kraenzl. ex J. Braun \& K. Schum., Mitth. Deutsch. Schutzgeb. 2: 161 (1889). Type: Cameroon, Braun 4 (holo. $\mathrm{B} \dagger$ ).

V. africana Lindl. subsp. cucullata (Kraenzl. ex J. Braun \& K. Schum.) Szlach. \& Olszewski in Fl. Cameroun 34: 286 (1988).

Perhaps not different from $V$. crenulata. In this species of the $V$. africana complex, the oblong-elliptic lip is acute, and the petals and sepals rather broader.

Collections: CAMEROUN: Zenker 525 (AMES! BM! G 7889/116/117 /118! P).

Source: Portères, R. 1954. Le Genre Vanilla et ses Espèces: 195-196.

28. V. decaryana H. Perrier in Bull. Mus. Hist. Nat. (Paris) 6: 194-195 (1934). Types: Madagascar, Domaine du Sud-Ouest: Morondava, Greve 39 (syn. P!); Ambovombe, Jan. 1925, Decary 3531 (syn. $\mathrm{P}$ !; isosyn. K!); Behara, E of Ambovombe, 17 Nov. 1931, Decary 9313 (syn. P!); Mahatomotsy, N of Ambovombe, 9 Dec. 1931, Decary 9503 (syn. P!).

Distribution: SW Madagascar.
Amemberof the V.roscheri-V.madagascariensis-V. phalaenopsis group, but with smaller more numerous flowers, greenish sepals, a column only 14-16 mm long and with narrower rhombic lip with the keels of the disc just to near the border of the lip, more conspicuous and with hairs shorter and not as fleshy. Collections: MADAGASCAR: O'Connor 98 (K drawing!).

Source: Du Puy, D., P. Cribb, J. Bosser \& J. \& C. Hermans. 1999. The Orchids of Madagascar: 207.

\section{$V$. denticulata Pabst $=$ V. odorata}

29. V. diabolica P.O'Byrne in Malayan Orchid Rev. 30: 67-70, figs. (1996). Type: Indonesia, Sulawesi, Tenggara-Buton Island, near Maligano, O'Byrne SB47V (holo. SING; drawing at K!).

This species is closely related to $V$. borneensis, but $V$. diabolica has elongated inflorescences, smaller flowers with two raised bodies at the base of the lip, shorter and broader tepals and a lip in which the veins of the throat are orange rather than purple.

30. V. dilloniana Correll in Amer. Orch. Soc. Bull. 15(7): 331, f. 1-7 (1946). Type: USA, Florida, Brickell Hammock, Dade County, Humes s.n. (holo. AMES).

Distribution: Cuba, Florida, Hispaniola, Puerto Rico, and Saint Thomas.

Distinguished by its starry flowers, conspicuously trumpet-shaped 3-lobed lip, edged with rich purple, in which the midlobe is triangular and longer, and with yellowish papillae towards the lip apex. The only known population in Florida has been wiped out, although plants survive in cultivation.

Although similar to the other leafless Caribbean species, it is easily distinguished when flowering material is at hand. Vanilla clavicula has an entire lip; from $V$. barbellata it is distinguished by its larger flowers and much longer midlobe of the lip. Many specimens bear small leaves, similar to those found in $V$. claviculata and $V$. poitaei, but rarely seen in $V$. barbellata. Vanilla poitaei has a larger lip and the margins are crisped.

Collections: CUBA: Wright s.n. (K-LINDL!); Jack 5200 (AMES!); Wright s.n. (AMES 70987, in part)! PUERTO RICO: Pennington s.n. (AMES 45836!); Pennington s.n. (AMES 43655!); Sintenis 3932 (BM!); Sintenis 4934 (K! fruits only). DOMINICAN 
REPUBLIC: Fuertes s.n. (AMES!). ST. THOMAS: Ostenfeld 235 (G7889/119!).

Sources: Ackerman, J.D. 1995. An Orchid Flora of Puerto Rico and the Virgin Islands: 171, fig. 93. Britton, N.L. and C.F. Millspaugh. 1962. The Bahama Flora: 83 (as V. eggersii). McCartney, C. 2000. African affinities. Orchids: 69(4): 341 (as $V$. dilloniana).

\section{$V$. domestica Hort., nomen $=$ ? $\boldsymbol{V}$. planifolia}

V. dominiana Hort. ex Gentil, Liste Pl. Cult. Serres Jard. Brux. 192 (1907), nomen.

\section{V. dressleri Soto Arenas ined.}

Distribution: Costa Rica, Panama and W Colombia.

This large-flowered species is a member of the $V$. hostmanii group. Among the group, it is distinguished by the rather lax inflorescence, with distant flowers (c. $1 \mathrm{~cm}$ apart), patent bracts, subentire lip, with a subrhombic blade, and very scarcely papillose sepals; $V$. cribbiana, $V$. hostmanii and $V$. ruiziana have conspicuously granulose sepals. From $V$. cribbiana it is additionally distinguished by the narrower, thinner leaves which are more long acuminate-cuspidate, laxer inflorescences, less defined apical lobe, veins of the disc more conspicuously thickened, and flowering time mostly in March-May, not in JulyAugust. Vanilla hostmanii from Amazonia has very long inflorescences which bear much more flowers (e.g. 40-50) and the leaves are larger, thicker, not as acuminate-cuspidate. Vanilla ruiziana, from Peru and Bolivia has larger, broader, less acuminate-cuspidate, and thicker leaves, but is similar to V. dressleri in their rather elevated axial keels of the lip. Vanilla gardneri from Brazil has a subacute lip apex and oblong leaves, not cuspidate.

Collections: PANAMA: Knapp \& Mallet 4621 (MO!); Williams in SEL 56-76-11[accession num.], Pridgeon s.n. (SEL 019244!; the leaves; flowers may belong to V. pseudopompona); Dressler, Luer, Luer \& Taylor 768 (SEL!). COSTA RICA: Haber 8471 \&. Cruz (CR MO!); Herrera 1840 (CR MO 3864177!); Liesner 14435 (MO!); Todzia 1291 (LL!); Lankester s.n. (SEL!). COLOMBIA: Cuatrecasas 16550 (AMES!); Cuatrecasas 15220 (AMES!); García C. \& Agualimpia 325 (MO!); Choco, Ingram 1421 (SEL!); Ingram 1422 (SEL!).
32. V. dubia Hoehne in Arq. Bot. Estado Sao Paulo n.s. 1: 126 (1944). Type: Brazil, Minas Gerais, BeloHorizonte, Schwacke 11107 (holo. RJ 37014!).

\section{Distribution: Brazil.}

Closely related to $V$. appendiculata, $V$. cristagallii and $V$. schwackeana, and with the characteristic papillose apical apex of the lip of many Brazilian species.

\section{V. duckei sensu Hoehne $(1945)=\boldsymbol{V}$. planifolia}

33. V. dungsii Pabst in Bradea 2, 10: 49 (1975). Type: Brazil: Estado do Rio de Janeiro, near Novo Friburgo, 1300 m, Febr. 1973, Dungs s.n. (holo. HB 59052!).

Distribution: Brazil.

Little is known of this species. It was stated in the original description that it is allied to $V$. cristatocallosa $(=V$. cristagallii $)$. The clump retrorse papillae towards the apex of the lip is certainly characteristic of that group of Vanilla.

\section{V. eggersi Rolfe $=\boldsymbol{V}$. poitaei}

\section{V. ensifolia Rolfe $=\boldsymbol{V}$. odorata}

\section{V. epidendrum Mirb. $=? \boldsymbol{V}$. mexicana}

34. V. edwalli Hoehne in Arq. Bot. Estado Sao Paulo n.s. 1: 61 . t. 81 (1941). Type: Brazil, Sao Paulo, Serra da Cantareira, Jan. 1902, Gustavo Edwall 6003 (holo. SP).

Distribution: Brazil and Argentina.

A species with long acuminate segments and a rather unornamented lip, except by the longitudinal lamellae. It is very probable that $V$. edwalii is a synonym of $V$. bertoniensis Bertoni, which original material has not been available to us. From $V$. parvifolia differs by its acuminate midlobe of the lip.

Collections: BRAZIL: Distrito Federal: cf. E.P. Heringer 5001 et al. (MG!).

\section{V. espondae Soto Arenas ined.}

Distribution: Endemic to Colombia.

This is one of the most beautiful Vanilla species. It has been found in the rainy, Pacific coast of Colombia and on a tributary of Magdalena River. Although is not closely related to any other Vanilla species, it could be related to $V$. trigonocarpa. It is distinguished by the very large papillae covering the lip apex.

\section{V. fasciola Spreng. $=$ Taeniophyllum fasciola}


36. V. fimbriata Rolfe in Bull. Misc. Inform. Kew 1899: 133 (1899). Type: Guyana (British Guiana), Barima River, Jenman 6771 (holo. K!; iso. K!).

Distribution: Brazil and Guyana.

Very close to $V$. odorata, or perhaps conspecific. The type material is not good enough to check the differences with $V$. odorata, but the flower size is smaller (the lip $25-50 \mathrm{~mm}$ long whereas it is 35 $45 \mathrm{~mm}$ in $V$. odorata). This could be a result of the preservation process. However, the leaves are rather shorter and the stems more floriferous than in any other $V$. odorata specimen that we have examined. Collections: PARA: Plowman et al. 9868 (MG!). Source: Portères, R. 1954. Le Genre Vanilla et ses Espèces: 245-247, fig. 111.

\section{$V$. fragrans Ames $=\boldsymbol{V} \cdot$ planifolia}

37. V. françoisii H. Perrier in Notul. Syst. (Paris) 8: 37 (1939). Type: Madagascar, S Toamasina, Ambilo, cult. François (holo. P!).

Distribution: Endemic to Madagascar.

A very rare species of which we have seen the type and one other collection. It was described as having slender stems, very small leaves and small, fewflowered racemes; the flowers have a trumpet-shaped lip with reflexed disc. It may well be conspecific with V. perrieri.

Collection: MADAGASCAR: between Ampanihy and Andraka, Capuron 479 (P!).

Sources: Portères, R. 1954. Le Genre Vanilla et ses Espèces: 180-181; Du Puy, D., P. Cribb, J. Bosser \& J. \& C. Hermans. 1999. The Orchids of Madagascar: 207.

38. V. gardneri Rolfe in Bull. Misc. Inform. Kew 1895: 177 (1895). Types: Brazil, Morro do Flamengo, near Rio de Janeiro, Gardner 245 (lecto., K! here designated); Parnagua District, Piauhy Prov., Gardner 2733 (syn. K!); Natividade, Goyaz, Gardner 3449 (syn. $\mathrm{K}$ !); Pernambuco, at Iguarassa, Ridley, Lea and Ramage s.n. (syn. K!); Burchell 894 (syn. K! sterile); near Rio, San José da Laranjeira, Gardner 9829 (syn. K! sterile).

\section{Distribution: Brazil.}

The entire, rhombic, subacute to obtuse lip of this species is very characteristic, and similar only to the Central American $V$. dressleri. It has also the thickened veins in the lip apex and the distichous arrangement of the basal bracts of the inflorescence characteristic of the $V$. hostmanii group. The species seem to be rare and we are basing our concept of this entity upon Hoehne's published drawing and the lectotype, since other materials are fragmentary or inadequate, and characters of the surface of sepals and ovary, typical of the $V$. hostmanii group, have not been examined.

The information on the lectotype, in Rolfe's handwriting, was probably obtained from a Gardner's note in Hooker, London Journal of Botany 1: p. 542; cited in the protologue. The original data are " 245 . Vanilla sp. Scentless. Climbing on the stump of an old Tree. Rio Comprido [?] common in the woods about Rio but seldom seen in flower. I could barely obtain 2 flowers. March 1836.”

The syntypes Ridley, Lea and Ramage s.n., Gardner 2733 and 3449 probably belong to V. bahiana, and are not conspecific with Gardner 245, selected here as the lectotype. Burchell 9828 has no flowers and the leaves are very different from the lectotype and it is doubfully conspecific with it.

Collections: BRAZIL: Glaziou 20709 (BM!).

SourCEs: Portères, R. 1954. Le Genre Vanilla et ses Espèces: 192; Pabst, G.F.J. 1966. Orquídea 28(2-6): 169-170.

39. V. giulianettii F.M. Bailey in Queensland Agric. J. 7: 350 (1900). Type: Papua New Guinea (British New Guinea), 15 Dec. 1909, Giulianetti 1906 (holo. BRI; iso. $\mathrm{K}$ !).

Distribution: New Guinea.

This scarcely known species has very large leaves, different from those of the New Guinean $V$. ramificans. However, we have not examined flowering specimens to compare it with the New Guinean vanillas described by Schlechter, which also have large leaves ( $V$. kaniensis, V. kempteriana and $V$. wariensis).

Collections: PAPUA NEW GUINEA: Morobe, Gillison NGF 25021 (K!); Western Dist., Ridsdale \& Galore NGF 33728 (K!); Northern Dist., Carr 17133 (BM!).

SourCE: Portères, R. 1954. Le Genre Vanilla et ses Espèces: 221.

40. V. grandiflora Lindl., Gen. Sp. Orch. Pl. 435 (1840). Type: French Guiana, Martin s.n. (holo. K-LINDL!). 
V. clavicula Duss, nomen.

V. lutescens Moq. ex Dupuis, Rev. Hortic. ser. 4, 5: 121, f. 24 (1856).

Distribution: Venezuela, Trinidad \& Tobago, Guyana, Peru, and Brazil.

Vanilla grandiflora has somewhat larger flowers that $V$. pompona (lateral sepals up to $8.4 \mathrm{~cm}$ in the type specimen). The sepals are narrower, subacute, the petals less rounded, and the lip has a subquadrate apex, not deeply notched as V. pompona.

Collections: GUYANA: Smith 2474 (G 7889/122! K!); im Thurm s.n. (K! K drawing!). VENEZUELA: Pittier 9460 (G 7889/ 149!). TRINIDAD \& TOBAGO: Hart 3 (K!); Broadway 4565 (BM!); Broadway 41912 (BM!); Hance 5285 (BM!). PERU: Klugg 3685 (BM!). BRAZIL: Rondonia, Rosa et al. 5060 (MG! fruit only); Rosa et al. 4915 (MG!); Roraima, Pires et al. 16778 (MG! fruits only).

Sources: Schweinfurth, C. 1958. Orchids of Peru I. Fieldiana: Botany 30: 43-44 (as V. pompona); Schultes, R.E. 1960. Native Orchids of Trinidad and Tobago: 42 (as V. pompona); Dunsterville, G.C.K. \& L.A. Garay. 1959. Venezuelan Orchids Illustrated 1: 434-435 (as V. pompona); Foldats, E. 1969. Flora de Venezuela. Orchidaceae 1: 125-127, fig. 43 (as V. pompona).

41. V. grandifolia Lindl. in J. Linn. Soc. Bot. 6: 138 (1862). Type: Principe (Prince's Island), Barter 1981 (holo. K! drawing K-LINDL! tracing W!).

Distribution: Democratic Republic of the Congo, Gabon, Principe Island.

This species is characterized by its large, broadly elliptic to suborbicular leaves, abruptely apiculate of rather thin substance. Floral morphology suggests a close relationship with $V$. imperialis, with a very large rostellum and a trumpet-shaped, concave lip, which is apiculate at apex (after drawings sent by de Wildeman to Kew). Porteres' fig. 85 (1954) shows a straight, undulate, entire lip lacking the characteristic apicule at apex.

Collections: PRINCIPE: Henriquez (K!); Monteiro (K!). Democratic Replublic of the Congo: Louis 2599 (B, K!) \& $10800(\mathrm{~K}$ !) de Wildemann s.n. (K fragment ex Berlin)!. GABON: Le Testu 6077 (BM! K!), 8445 (BM! K!) \& 9308 (BM! K!).

Sources: Portères, R. 1954. Le Genre Vanilla et ses Espèces: 176-178, fig. 85; Szlachetko, D.L. \& S.
Olszewski. 1999. Fl. de Cameroun: 292, t. 103, G-K.

V. grandifolia var. lujae (De Wild.) Geerinck $=\boldsymbol{V}$. imperialis

\section{V. gratiosa Griseb. $=$ V. bicolor}

42. V. griffithii Rchb. f. in Bonplandia (Hanover) 2: 88 (1854). Types: Malacca, Griffith 281 (lectotype W, here designated); Tabong, Malacca, 1844, Griffith s.n. (syn. K-LINDL! probable duplicate at AMES 71377!).

V. tolypephora Ridl. in Trans. Linn. Soc. London, Bot. 3: 276 (1893). Type: Malaysia, Penang and the Island Pulau Ubin, lying in the strait between Singapore and Johore, and in Selangor, Singapore collector 3924 (holo. BM!).

Distribution: Peninsular Malaysia, Singapore, Borneo (Brunei), Sumatra. Expected from S- Thailand.

Vanilla griffithii is a distinct species because the "ball" of hairs instead of the penicillate callus of allied species. The midlobe is itself deeply bilobed. The floral buds are very truncate-rounded. Sterile collections can be identified by the very broad leaves and many capsules on the inflorescences, as if they be self-pollinated.

Collections: MALAYSIA: Griffith s.n. (K-LINDL!); Griffith 7401 (K-LINDL!); Griffith s.n. (AMES!); Ridley 1969 (BM!); Curtis 2271 (K!); Wray in King 2537 (K!); King 2996 (K!); King 7528 (K!); Maingay 1660 (K!) \& 3255 (K!); Scortechini s.n. (K!); Curtis 1179 (K!); Henderson 20378 (K!); Ngadiman in Henderson s.n. (K!); Ahmad S.324 (K! sterile); Sidek bin Kiah S.248 (K!); Whitmore FRI 3706 (K!); Negri Sembilan, FRI 27529 (K!); Evans s.n. (K!); Tahit 1233 (K!); Mondi 289 (K! fruits only); Leopold \& Ag. Amin SAN 86237 (K! fruits only); Collenette 643 (K!); Scortechini 1080 (K!); Cheng FRI 27529 (K!); Perlis, Kaboch 15197 (K!). SINGAPORE: Lobb 226 (K!); Curtis (K!); Ridley 3924 (BM!). BRUNEI: Johns 7456 (K!); Wong 974 (K!); Boyce 452 (K!).

SourCEs: Ridley, H.N. 1924. The Flora of the Malay Peninsula: 201; Portères, R. 1954. Le Genre Vanilla et ses Espèces: 168-169; Teo, C.K.H. 1985. Native Orchids of Peninsular Malaysia: 107-108. Seidenfaden, G. \& T. Smitinand. 1959. The Orchids of Thailand: a preliminary list, part 1: 58; Seidenfaden, G,. 1978. Orchid Genera in Thailand VI. Dansk Bot. Arkiv. 32(2): 142, 144, fig. 89; Holttum, R.E. 1964. Flora of Malaya. Orchids: 95-96, fig. 16c. 
V. griffithii Rchb. f. var. ronoensis (Hayata) S.S. Ying $=$ V. somai

43. V. guianensis Splitg. in Ann. Sci. Nat. Bot. s. 2, 15: 279 (1841). Type: Surinam, Splitgerber 409 (holo. $\mathrm{P}$ ?).

?V. surinamensis Rchb. f. in Ned. Kruidk. Arch. 4: 321 (1859). Type: Based upon same type as $V$. guinanensis Splitg.

V. acuta Rolfe in J. Linn. Soc. Bot. 32: 453 (1896).

Type: Surinam, Marowyne, Aug. 1846, Kappler (holo. K-LINDL!).

V. latisegmenta Ames \& C. Schweinf., Sched. Orchit. 8: 2 (1925). Type: Guyana (British Guiana), Upper Rupununi River, near Dadanawa, 29 May 1922, de la Cruz 1404 (holo. AMES 22973!; iso. GH 7850!).

Distribution: Guyana, Surinam, and Brazil.

Vanilla guianensis has been regarded as an obscure species. Splitgerber, in the original description, mixed a species of the membranaceous group with the fragrant fruits of a penicillate species, perhaps $V$. grandiflora. The illustration that appeared in De Vriese, Tuinb.-Fl. 3: 33.1856 , clearly illustrates the mistake, and it is not accurate with respect to the flower and inflorescence structure, since the inflorescence, if short and with small bracts for a species of the Membranaceous group, is densely-flowered, and the lip is rather deeply 3-lobed.

Rolfe (1896) recognized Splitzgerber's mistake and reduced $V$. guianensis to the synonymy of $V$. inodora (his concept including specimens that here we recognize as $V$. inodora, $V$. mexicana, and $V$. guianensis) and considered Reichenbach's proposal of V. surinamensis as an error. However, Rolfe described Vanilla acuta in the same revision, based on a Kappler specimen and cited a Schomburgk illustration at the British Museum from the Berbice River, as probably belonging to the same species. We agree that Kappler's and Schomburgk's specimens are conspecific, although it is evident that the original description was based upon an open bud, very damaged by the dissection. The very short inflorescence with small bracts, and rather chartaceous texture of leaves are very characteristic for a membranaceous species.

Later, Ames and Schweinfurth (1925) described $V$. latisegmenta. Their description is very good and the type well-preserved and with analytical drawings and matches very well with the several specimens listed below from the Guyanas and Amazonia.

This is a large flowered species that seems to be very close to $V$. mexicana, but it is distinguished by its much broader lip (45-50 vs. $30 \mathrm{~mm}$ broad), which is not as distinctly 3-lobed, but approaching hexagonal with the apical lobe very broadly ovate, or obscurely defined, its few-flowered inflorescence (bearing only 4-5 flowers), shorter than $10 \mathrm{~cm}$, usually $4-5 \mathrm{~cm}$ long and the small, ovate, acuminate bracts. Vanilla martinezii from Guatemala has also a subentire, very broad lip, but in this species the veins are warty in the basal half, and the raceme is longer. In dried specimens the very broad lip in which veins are strongly marked is very distinct.

Collections: BRAZIL: Huber s.n. (BM! MG 1864!); Huber 1864 (G 78889/105!); Photo of plant in habitat, Arboretum amazonicum (as $V$. aromatica Sw.) (K). GUYANA: Schomburgk s.n. (BM NY! photo, $\mathrm{K}$ ! tracing from drawing at $\mathrm{BM}) . ;$ Kaituma River, M.W.D. 211 (K!); Im Thurm 64 (K!); Jenman 689 (K!); Jenman 1614 (K!); Barkley s.n. (K! painting). SURINAM: Hostmann 71 (K!).

Sources: Portères, R. 1954. Le Genre Vanilla et ses Espèces: 255, fig. 115 (as $V$. acuta); Werkhoven, M. 1986. Orchids of Suriname: 228, 236 (as V. mexicana Mill.).

44. V. hallei Szlach. \& Olszewski in Fl. Cameroun 34: 282 (1998). Type: Gabon, Belinga, N. Hallé 3065 (holo. P!).

Distribution: Endemic to Gabon.

This species is closely related to $V$. africana. However, the lip is fleshier, fused to the column in the basal $1 / 4$, and with papillae in the disc rather than long bristles.

45. V. hamata Klotzsch in Bot. Zeitung (Berlin)-55: 563 (1846). Type: Peru, Pavón s.n. (holo. B †, photo. AMES 38629! sterile, iso. BM! G 7889/123 124, W!).

Distribution: Endemic to Peru.

We have dissected floral buds (not attached to an inflorescence) at G and BM. It is a species of the $V$. pompona group, with large tepals (e.g. petals at least 63 $\times 8 \mathrm{~mm}$ ), with a rather smooth lip, a callose, penicillate callus, and a thickened axial cushion in the apical 
part of the lip. The lip is trilobed, with the midlobe projecting and perhaps emarginate. However, it seems to be distinct from all the known species in that group, particularly by the widely elliptic, rounded leaves.

Another, well-preserved bud from the G specimen is perhaps an Epistephium species, because of its numerous retrorse hairs and lip scarcely fused to the column.

Sources: Portères, R. 1954. Le Genre Vanilla et ses Espèces: 233; Schweinfurth, C. 1958. Orchids of Peru 1: 42-43. Fieldiana: Botany 30.

46. V. hartii Rolfe in Bull. Misc. Inform. Kew 1899 (151/152): 133 (1899). Type: Trinidad, Cabasterre Arima, Hart 6355 (holo. K!; iso. AMES 67785!).

V. leprieurii Portères in Bull. Soc. Bot. France, 98:

94. 1951. Type: French Guyana, Cayenne, 1846, Leprieur s.n., (holo. P not seen, drawing!).

Distribution: Mexico to Brazil and French Guyana.

Vanilla hartii is an interesting species with a weak vegetative habit similar to that of $V$. bicolor. However, it presents flowers, and especially a penicillate callus with the structure of the $V$. planifolia group, with which it has been confused.

Vanilla lepriurii is considered here to be a synonym of $V$. hartii. Portères (1954) stressed that his $V$. leprieurii was distinct because the nervation in the center of the lip is denser, with the zone before the nervation thicker, more imbricated scales in the penicillate callus, and the apex of the lip more emarginate, apiculate and pleated.

Vanilla hartii has not been previously reported from Brazil, but we have a herbarium specimen and two unidentified leaf samples whose ITS DNA sequences indicate that they belong to $V$. hartii. The collections from Costa Rica are very stout.

Collections: COSTA RICA: Grayum 7998 (MO!). HONDURAS: Standley 52824 (AMES!). BELIZE: Davidse 36251 (BM!). TRINIDAD \& TOBAGO: Britton 2841 (AMES!); Broadway s.n. (AMES! in part K!); Fendler 1007 (BM! K!). DOMINICA: Hodge 387 (AMES! sterile). BRAZIL: Rabelo \& Pen 720 (MG! sterile).

Sources: Portères, R. 1954. Le Genre Vanilla et ses Espèces: 248, fig. 12 (as V. leprieurii) and 250-251, fig. 113; Schultes, R.E. 1960. Native Orchids of Trinidad and Tobago: 39.
47. V. havilandii Rolfe in Bull. Misc. Inform. Kew 1918: 236 (1918). Types: Sarawak, Kuching, Haviland s.n. (syn. K!); Sarawak, Matang, Ridley s.n. (syn. K!).

Distribution: Borneo.

A species somewhat similar to the Javanese $V$. albida, but with congested, many-flowered inflorescences bearing pendent flowers, apparently with flared tepals. The oblong-elliptic, long-acuminate leaves are rather thin in substance.

Collections: MALAYSIA: SARAwaK, BRoOKE 8181 (G 7889/181!); LAMB SAN 89632 (K!); SANDS ET AL. 3702 (K!); CHAN 927 (K!, DRAWING). INDONESIA: Kalimantan, Afriastini 310 (K!).

Source: Portères, R. 1954. Le Genre Vanilla et ses Espèces: 209-210.

48. V. helleri A.D. Hawkes in Phytologia 14 (1): 19, t. 13. (1966). Type: Nicaragua, Dept. Chontales, 2 miles $\mathrm{S}$ of La Libertad on the road to Santo Tomás, $1900 \mathrm{ft}$, April 1962, Heller 7946 (holo. AMES not located; iso. SEL!).

Distribution: Nicaragua and Costa Rica.

This is one the rarest of the Central American Vanilla species. It has relatively small flowers with a distinct 3-lobed lip, in which the midlobe is covered with retrorse, complanate, elongate trichomes, resembling in some way the South American $V$. ribeiroi. It is a member of the $V$. odorata- $V$. insignis complex, also with retrorse, orange trichomes on the midlobe.

Collections: COSTA RICA, Davidse \& Pohl 1503 (F!).

Sources: Hamer, F. 1984. Ic. Pl. Trop. Pl. 1192; Hamer, F. 1990. Orch. Centr. Amer. Selbyana 11: 847.

49. V. heterolopha Summerh. in Bull. Misc. Inform. Kew 1938: 149 (1938). Type: Gabon, Upper Ogoué River, Matoro, Oct. 1929, Le Testu 7494 (holo. P!; iso. $\mathrm{BM}$ ! K!).

Distribution: Gabon and Congo.

This species is a member of the $V$. africana group, resembling vegetatively $V$. africana, but it is easily distinguished by its truncate, rectangular, sharply recurved midlobe of the lip, and warts and papillae in the center of the blade. When flattened, the midlobe of the lip appears slightly broader towards the apex. In the other members of the $V$. africana group, the apical 
lobe of the lip is acute to acuminate, with retrorse, fimbriate scales, rather than warts.

Collections: GABON: Le Testu 5769 (BM! K drawing!); Le Testu s.n. (K!); Le Testu 7494bis (BM!). SourCE: Portères, R. 1954. Le Genre Vanilla et ses Espèces: 206-207, fig. 96; Szlachetko, D.L. \& S. Olszewski. 1999. Fl. de Cameroun: 282, pl. 100, G-M.

V. hirsuta M.A. Clem. \& D.L. Jones $=\boldsymbol{V} . \times$ tahitiensis

50. V. hostmannii Rolfe in J. Linn. Soc. Bot. 32: 462 (1896). Type: Surinam, Hostmann 306 (holo. K!, iso.K-LINDL!).

?Vanilla planifolia var. gigantea Hoehne, Com. Lin. Tel. Est. M.G. Amazonas, Bot. 1: 217 (1910).

V. barrereana Veyret \& Szlach. in Bull. Mus. Natl. Hist. Nat., B, Adansonia 16 (2-4): 220 (1995). Type: French Guiana, Cremers 4523 (holo. P, iso. CAY).

V. porteresiana - Szlach. \& Veyret in Bull. Mus. Natl. Hist. Nat.,B, Adansonia 16 (2-4): 219 (1995). Type: French Guiana, Oldeman 2087 (holo. P).

Distribution: Colombia, Guyana, French Guiana, Surinam, Venezuela and Brazil.

Vanilla hostmanii is a member of a small group of species that includes also $V$. cribbiana, $V$. dressleri, and $V$. weberbaueriana, characterized by the conspicuously distichous arragement of the basal bracts, its entire to obscurely trilobed lip adorned with thickened, papillose veins on the lip apex, and with the ovary, sepals and the petals keels oddly granulose. From them is distinguished by its many-flowered racemes, larger leaves, a more thickly veined lateral lobes of the lip. It has cream-colored flowers.

Vanilla barrereana and $V$. porteresiana, described by Veyret \& Slatchetko (1995), have the characteristic thickened veins and granulose sepals surface but have smaller measurements and different lip tips. We have compared them with immature buds of $V$. hostmanii and we believe than they are better considered synonyms of $V$. hostmanii. Several specimens of $V$. hostmanii have been annotated as $V$. planifolia var. gigantea, but we have been unable to locate the type specimen of this variety to confirm if it is a synonym of $V$. hostmanii or of $V$. grandiflora ( $=V$. pompona sensu Hoehne), as stated by Hoehne in 1945 .
Vanilla hostmanii seems to be a common species in Guyana and the Amazon.

Collections: GUYANA: Anderson 71 (K!); Jenman $89 \& 6390$ (K!); im Thurn 65 (K!). COLOMBIA: Lehmann H.K. 1187 (K!); Schultes 3809 (AMES!). BRAZIL: Acre, Prance 7955 (MG!).; Para, Wullschlaegell s.n. (W!); Prance et al. P25739 (K! MG!); Maciel \& Santos 1939 (MG!). Amazonas, Silva \& Brazâo 60960 (VEN!). VENEZUELA: Wurdack \& Adderley 43074 \& 43170 (VEN!).

Sources: Portères, R. 1954. Le Genre Vanilla et ses Espèces: 193; Hoehne, F.C. 1945. Flora Brasilica 12, 2: Orchidaceae: 18.

51. V. humblotii Rchb. f. in Gard. Chron. n.s. 23: t. 726 (1885). Type: Grande Comore, Humblot 1413 (holo. W!, iso. BM! K! P!).

Distribution: Comoros Islands.

Another member of the $V$. roscheri group distinguished by its yellow flowers with dark maroon marks in the throat of the lip.

Collections: COMOROS: Mayotte, Labat 2905(P,K!). SourCES: Rolfe, R.A. 1905. Bot. Mag. t. 7996; DuPuy, D. Cribb, P., Bosser, J. \& Hermans, J. \& C. 1999. The Orchids of Madagascar: 207.

52. V. imperialis Kraenzl. in Notizbl. Bot. Gard. Berlin-Dahlem 1: 155, t.1 (1896). Type: Cameroon, Yaoundé, Zenker \& Staudt 626 (holo, B $\dagger$ ).

V. lujae De Wild., Belg. Colon. 10: 28 (1904). Type: Zaire, Luja s.n. (holo. BR).

V. grandifolia Lindl. var. lujae (De Wild.) Geerinck in Bull. Soc. Roy. Bot. Belgique 107, 1: 58 (1974).

V. imperialis Kraenzl. var. congolensis De Wild. in Rev. Hist. Nat. Appl. (Paris) 2: 188 (1921). Type: Zaire, Dundusana, Mortehan 244 (holo. BR).

Distribution: Sierra Leone, Ivory Coast, Ghana, Nigeria, Cameroun, Democratic Republic of the Congo, Angola, Uganda, United Republic of Tanzania, Kenya.

This common African species has the most spectacular flowers in the genus, which are big, ivorywhite, heavily veined-blotched with deep rose to purple. The inflorescence has many imbricate bracts, resembling some species of Costus, however, many specimens from East Africa have shorter bracts. It is 
closely related to $V$. ochyrae and to $V$. polylepis (see comments under the species).

Collections: CAMEROUN: Bates 1523 (BM!). GHANA: Westward 113, 226 (K!); Vigne 2412 (K!); Hall GC 35391 (K!). SIERRA LEONE: Assi 9041 (K!); Jaeger 40 (G 78889/184 185!); Jaeger 16566 (K!). NIGERIA: Chapman 4869 (K!). UGANDA: Eggeling 2062 (K!); Dümmer $2672(\mathrm{~K} !), 2672 \mathrm{~A}$ (BM!) Eggeling 1065 (K!); Ussher 83 (K!); Poulsen et al. 971 (K!); Bagshawe \& Camb 1142 (BM!); van Someren E.A.H. 11163 (EAH, K). TANZANIA: Moreau 429 (K!); Greenway 6664 (K!); Greenway 2928 (K!). ANGOLA: Rep. de Agricultura 14214 (K!); Gossweiller 13837 (BM!).

Sources: Rolfe, R.A. 1897. Flora Trop. Afr. 7: 178; Robyns, F.H. \& R.L. Tournay. 1955. F.P.N.A. 3: 454; Portères, R. 1954. Le Genre Vanilla et ses Espèces: 174-176, fig. 84 and 178-179 (as V. lujae); Summerhayes, V.S. 1968. Flora of West Tropical Africa 3(1): Orchidaceae: 205-206; Piers, 1969. Orch. E. Afr. ed. 2: 82, fig. 26; Cribb, P. 1984. Flora of Tropical East Africa. Orchidaceae 2: 259261; Geerinck, D. 1984. Flore D'Afrique Centrale (Zaire, Rwanda-Burundi): 244-246; Stewart, J. 1996. Orchids of Kenya: 89; Szlachetko, D.L. \& S. Olszewski. 1999. Fl. de Cameroun: 290-291, pl. 103, A-E.

53. V. inodora Schiede in Linnaea 4: 574 (1829). Type: Mexico, Schiede s.n. (holo. BM!, iso. LE, W!).

V. preussii Kranzl. in Notizbl. Bot. Gard. BerlinDahlem 7(67): 320 (1919). Type: Guatemala, Preuss 1445 (holo. B†).

V. pfaviana Rchb.f. in Gard. Chron. n.s. 20: 230 (1883). Type: Costa Rica, Pfau s.n. (holo. W!).

Distribution: Mexico, Belize, Guatemala, Honduras, Nicaragua, Costa Rica and perhaps Panama.

This is the species of the membranaceous group with most northern distribution. It is distinguished by the high, thick cushion-like, axial callus of its emarginate lip.

Collections: MEXICO: Liebman 297 (K!); Liebman 284-296 (BM!); Liebman 7268 (BM!); Calzada 01031 (BM!). Veracruz, Nagel in Oestlund 2683 (AMES!); Purpus in Oestlund 4876 (AMES!); Purpus in Oestlund 5045 (AMES!); Purpus 8481 (AMES!). Puebla, Arsène 1682 (AMES!).; Guerrero:
Nagel in Oestlund 1984 (AMES!), 1985 (AMES! BM!).; Chiapas: Matuda 17912 (AMES!). BELIZE: Gentle 1672 (AMES!). GUATEMALA: Steyermark 49171 (AMES!). HONDURAS: Yuncker et al. 8335 (AMES!). COSTA RICA: Skutch 2592 (AMES! K!); Lankester K331 (K!); von Wedel 1423 (BM!).

Source: Portères, R. 1954. Le Genre Vanilla et ses Espèces: 252-253 (mixed with V. mexicana) and 257 (as V.pfaviana).

54. V. insignis Ames in Bot. Mus. Leafl. 2: 101 (1934). Type: Honduras, Edwards 407 (holo. AMES 40085!).

Distribution: Mexico, Guatemala, Belize, Honduras, reported by Dressler (1993) for Costa Rica.

This common Mesoamerican species has rarely been collected in flower. Its flowers with large apple green tepals and a cream-colored lip bearing orangeochre retrorse papillae are characteristic. Sterile plants can be distinguished by their sulcate stems with minutely papillose surface. It is a member of the $V$. odorata group, but it has shorter leaves and more xerophytic habit.

Collections: MEXICO: Oaxaca, Nagel in Oestlund 4584 (AMES!).; Veracruz, Nagel in Oestlund 2682 (AMES!); Purpus in Oestlund 4866 (AMES!); Purpus in Oestlund 5961 (AMES!).; Quintana Roo, Nagel in Oestlund 4973 (AMES!). BELIZE: Gentle 1063 (AMES!). GUATEMALA: Steyermark 45233 (AMES!).

Sources: Portères, R. 1954. Le Genre Vanilla et ses Espèces: 231-233, fig. 107. Dressler, R.L. 1993. Field Guide to the Orchids of Costa Rica and Panama.

55. V. kaniensis Schltr. in Repert. Sp. Nov. Regni Veg. Beih. 1: 32 (1911). Type: Papua New Guinea, Schlechter 17634 (holo. B $\uparrow$; published drawing!).

Distribution: Bismarck Mountains, Papua New Guinea.

Similar to $V$. kempteriana and $V$. wariensis, but with smaller $(20-25 \times 4-7 \mathrm{~cm})$ leaves.

Sources: Portères, R. 1954. Le Genre Vanilla et ses Espèces: 221; Howcroft, N.H.S. 1984. A Guide to the monocotyledons of Papua New Guinea. R.J. Johns \& Hay, A.J.M. (eds.) 4. The Orchidaceae (in part): Forestry Department PNG, University of Technology. p. 126, fig. 72; O'Byrne, P. 1994. Lowland Orchids of Papua New Guinea. SNP Ltd. p. 9. 
56. V. kempteriana Schltr. in Repert. Sp. Nov. Regni Veg. Beih. 1: 32 (1911). Type: New Guinea, Schlechter 18045 (holo. B †; published drawing!; iso.G!).

Distribution: Papua New Guinea, between Lae and Madang.

Distinguished from other species from the island by its rather broad leaves.

Sources: Portères, R. 1954. Le Genre Vanilla et ses Espèces: 220-221; Howcroft, N.H.S. 1984. A Guide to the monocotyledons of Papua New Guinea. R.J. Johns \& Hay, A.J.M. (eds.) 4. The Orchidaceae (in part): Forestry Department PNG, University of Technology. p. 126, fig. 73; O’Byrne, P. 1994. Lowland Orchids of Papua New Guinea. SNP Ltd. p. 9.

57. V. kinabaluensis Carr in Gard. Bull. Straits Settlem.8: 176 (1935). Types: Borneo, Carr 3157 (syn. K!); Kadamaian (Tampassuk) River, at the entrance to Menetendok Gorge, c. 2,700 feet, March 1933, Clemens 26300 (syn. BM!); Dallas, 3,000 feet, Aug. 1931; Clemens 26725 (syn. BM! K!); Dallas, 3,000 feet, 15 Sept. 1931, Clemens (syn. K).

Distribution: Borneo (Sabah) and Peninsular Malaysia.

Very similar to the Bornean $V$. abundiflora J.J. Sm., but with larger flowers, a more distinctly 3-lobed lip with a median keel and without irregularly seriate warts. The column lacks the appendages found in $V$. abundiflora. It is recognized by its extremely long raceme, sometimes with up to 165 flowers, which open successively perhaps during much of the year. Collections: MALAYSIA: Sabah, $S F N-25273$ (K!); Joseph \& Donggop SAN 128637 (K!); Wood 909 (K!, and drawings); Lamb 1230/90 (K!); Lugas 1724 (K!); Burbidge s.n. (BM! K drawings!).

Sources: Portères, R. 1954. Le Genre Vanilla et ses Espèces: 216; Holttum, R.E. 1964. Flora of Malaya. Orchids: 96-97.

\section{V. klabatensis Schltr. nomen nudum.}

V. latisegmenta Ames \& C. Schweinf. $=\boldsymbol{V}$. guianensis

$V$. laurentiana De Wild. $=\boldsymbol{V}$. crenulata

V. leprieurii Portères $=\boldsymbol{V}$. hartii

V. lindmaniana Kraenzl. $=\boldsymbol{V}$. palmarum

V. lujae De Wild. $=\boldsymbol{V}$. imperialis

LANKESTERIANA 9(3), January 2010. C Universidad de Costa Rica, 2010.
V. lutea C.H. Wright ex. Griseb. =V palmarum

$V$. lutescens Moq. ex Dupuis $=\boldsymbol{V}$. grandiflora

58. V. madagascariensis Rolfe in J. Linn. Soc. Bot. 32: 476 (1896). Type: Madagascar, Bomatoe Bay, Bojer s.n. (holo. K!).

Distribution: Madagascar.

Vanilla madagascariensis is very similar to $V$. phalaenopsis from the Seychelles and V.roscheri from E Africa. All three have large, white flowers with pink to apricot throat to the lip, but they differ in the lip lobing. They have some of the most spectacular flowers in Vanilla.

Sources: Du Puy, D., Cribb, P. Bosser, J. \& Hermans, J. \& C. 1999. The Orchids of Madagascar: 207, pl. $42 \mathrm{~B}, 43 \mathrm{C}$.

\section{V. majaijensis $\mathrm{Blanco}=? \boldsymbol{V}$. planifolia}

$V$. marowynensis Pulle $=\boldsymbol{V}$. appendiculata

\section{V. martinezii Soto Arenas, ined.}

Distribution: Guatemala, expected from Belize and Honduras.

$V$. martinezii is member of the $V$. mexicana group. The most similar species is $V$. guianensis, however in $V$ guianensis the callus is formed by 5 basal keels and 3 rather prominent ones, but not or almost not verrucose, and the lip apex is trilobed. V. martinezii seems to be endemic of the wet lowlands around Lake Izabal.

60. V. methonica Rchb. f. \& Warsz. in Bonplandia 2: 97 (1854). Type: Colombia (New Granada), 6-8000ft., Warscewicz s.n. (holo. W19363!; iso. K-LINDL!).

Distribution: Colombia and Peru, apparently only on the eastern slopes of the cordillera.

We have seen very few specimens referable to this species, and the type is poorly preserved. However, the protologue is good enough to identify their specific concept with modern specimens from Peru.

The rather short inflorescences (for the membranaceous group), with small, broadly ovate bracts and the large flowers with a strongly 3-lobed lip, in which the lateral lobes are oblong and rounded and the emarginate midlobe are characteristic. Like many others in the V. mexicana group, it has 3 longitudinal keels, converging on the lip apex, but the keels are thickened in the distal part and somewhat rugose. It 
seems to be more closely related to $V$. inodora, but it lacks the characteristic cushion-like, massive callus of that species.

$V$. oroana Dodson, from the Pacific slopes of Ecuador, has very large foliaceous bracts, the tepals are strongly contorted, and it has 5 apical keels on the acute lip; no other membranaceous vanilla is known from Andean South America.

Collections: COLOMBIA: Barragán in Lehmann HK1181 (K!); Goudot s.n. (W sketch!). PERU: Smith 3883 (MO!); Vargas 18697 (AMES!).

Source: Portères, R. 1954. Le Genre Vanilla et ses Espèces: 254-255.

61. V. mexicana Mill., Gard. Dict. (ed. 8), no. 1 (1768). Type: Haiti, Plumier s.n. (holo. Plumier's original drawing at $\mathrm{P}$; reproduced in Plumier, Nov. Pl. Amer. Genera 25, pl. 28, 1703!).

Epidendrum vanilla L., Sp. Pl. 2: 952 (1753). Type: "Volubilis siliquosa plantaginis folio" in Catesby, Nat. Hist. Carolina 2 (?3): app. t. 7. 1747; lecto. designated by Cribb in Cafferty \& Jarvis, Taxon: 48(1): 47. 1999).

V. aromatica Sw. in Nova Acta Regiae Soc. Sci. Upsal. 6: 66 (1799). Type: based on same type as Epidendrum vanilla $\mathrm{L}$.

V. anaromatica Griseb., Fl. Brit. W. Ind. 638 (1864). Type: Based upon Plumier, Ed. Burm., t. 188.

V. epidendrum Mirb., Hist. Nat. Pl. 9: 249 (1802-6).

V. vanilla (L.) Huth in Helios 11(9): 136 (1893).

Distribution: U.S.A. (Florida), Cuba, Puerto Rico, Hispaniola, Lesser Antilles, Trinidad and Tobago, perhaps N. South America (Venezuela). Reported repeatedly from Guianas and Brazil, but the examined material belongs to $V$. latisegmenta or other taxa.

The taxonomic history of this species is very confusing. Mexican specimens referred to this species belong to $V$. inodora. Its lip is 3-lobed, the midlobe is well-developed and can be subacute to rounded. It is closely related to $V$. costaricensis with a truncate lip, to $V$. ovata and $V$. martinezii with larger flowers, and the latter with many warts near the base of the lip.

Some authors have considered $V$. inodora as the valid name of this species. Although the type of $V$. inodora is lacking flowers, there is abundant material from the original area to establish that it is the species common in Mesoamerica that has a thick, longitudinal cushion-like callus and is widely known as $V$. pfaviana. The West Indies taxon with a callus formed by 3 longitudinal keels it is unknown in Mexico.

Collections: PUERTO RICO: Sintenis 1739 (K!); Sintenis 2456 (AMES!); Sintenis 2486 (G 7889/104, /107!); Sintenis 5469 (AMES! BM! G 7889/128! $\mathrm{K}$ ); Eggers 1076 (G 7889/ 178!); Eggers 1322 (K!); Kevorkian 6468 (AMES!). CUBA: Wright 3353 (AMES! K!); Alain \& Acuña 2295 (AMES!); Clemente 2401 (AMES!); Britton \& Wilson 5221 (AMES!); Schafer 3211 (AMES!), 3299 (AMES!) \& 7982 (AMES!); JAMAICA: Purdie s.n. (K!); Morris 451 (K!); Wood s.n. (BM tracing!). TRINIDAD AND TOBAGO: Baker 14732 (K!); Britton \& Howell 2847 (K!); Britton \& Howell s.n. (AMES!); Broadway 3874 (K!); Crueger s.n. (K!); Freeman s.n. (AMES!); Simmonds 334 (AMES!); Britton 2945 (AMES!); Row \& E.E.C. 11332 (AMES!). GUADELOUPE: Smith 10350 (AMES!). DOMINICA: Immary 138 (K!); Ramage s.n. (K!); W.H. and B. T. Hodge 3671 (AMES!); Ernst 1462 (AMES!). ST. LUCIA: Proctor 17710 (AMES!). DOMINICAN REPUBLIC: Eggers 2086 (K!). HAITI: Eyerdam 395 (AMES!); Zanoni \& García 42003 (AMES!). MARTINIQUE: Duss 2081 (AMES!).

Sources: León, F.S.C. \& F.S.C. Alain.1946. Flora de Cuba I: 351 (as V. inodora); Portères, R. 1954. Le Genre Vanilla et ses Espèces: 252-253 (mixed up and as V. inodora); Schultes, R.E. 1960. Native Orchids of Trinidad and Tobago: 40 (as Vanilla inodora); Kenny, J. 1988. Native Orchids of the Eastern Caribbean: 22; Acuña, G.J. 1939. Catálogo Descriptivo de las Orquídeas Cubanas: 21 (as V. inodora); Dunsterville, G.C.K. \& L.A. Garay. 1959. Venezuelan Orchids Illustrated 1: 432-433 (as V. inodora); Foldats, E. 1969. Flora de Venezuela. Orchidaceae I: 118, fig. 39 (as V. inodora); Ackerman, J.D. 1995. An Orchid Flora of Puerto Rico and the Virgin Islands: 174; Cafferty \& Jarvis, Taxon: 48(1): 47. 1999. Lectotypification of Epidendrum vanilla.

V. microcarpa H. Karst., Deut.sehe Fl. 458 (1880-83). Type: Venezuela

Poorly known species.

V. montagnacii Portères in Bouriquet, Vanillier et Vanille 46: 282 (1954), nom. inval. Based upon: 
Madagascar, P.R. Montagnac 146 (not seen)

This species has an entire lip with two subpapillose keels on its disc. It is possibly a semi-peloric form of $V$. decaryana or $V$. madagascariensis which are both found in the region. Portères failed to provide a Latin description of this name which is consequently invalid. Collections: MADAGASCAR: N of Morondava, Bosser 18187 (P!); Abraham 78 (P!).

62. V. montana Ridl. in J. Fed. Malay States Mus. 6: 58 (1915). Type: Malaya, Perak, Gunong Kerbau, 4400 - 5500 ft, 19 March 1913, Robinson s.n. (holo. $\mathrm{K}$ !; iso.AMES 25073! BM!).

Distribution: Malaysia.

Seidenfaden considered this species to be conspecific with Thai plants identified by him as $V$. albida, but thought by us to be V. yersiniana. However, it differs from $V$. yersiniana by the much longer hairs at the lip apex (up to $4 \mathrm{~mm}$ long) and much broader leaves. It seems to be a rare plant and as far as we know it is only known from the type specimen.

Sources: Ridley, H.N. 1924. The Flora of the Malay Peninsula: 201; Portères, R. 1954. Le Genre Vanilla et ses Espèces: 222; Holttum, R.E. 1964. Flora of Malaya, ed. 3. Orchids: 97.

63. V. moonii Thwaites, Enum. Pl. Zeyl. 312 (1864). Type: Sri Lanka, Thwaites 3204 (holo. K!; iso. AMES 71375! BM! G!).

Distribution: Endemic to Sri Lanka.

This species has 2 rows of papillae at the apical lobe of the lip, in the way of many other Asian species. The simple raceme, with many (up to 21) flowers on a thick rachis is also characteristic.

Collections: SRI LANKA: Wight s.n. (K!); Champion (AMES! K-LINDL!); collector 1869 (K!).

SourCEs: Portères, R. 1954. Le Genre Vanilla et ses Espèces: 182; Jayaweera, D.M.A. 1981. Orchidaceae. A Revised Handbook to the Flora of Ceylon 2: 333.

64. V. nigerica Rendle, Cat. Pl. Oban 108 (1913). Type: S. Nigeria, Oban, 1911, Talbot 776 (holo. BM!).

\section{Distribution: Nigeria and Cameroon.}

A species of the $V$. chalotii group. It is similar to $V$. seretii, both being characterized by their narrowly oblong leaves, verrucose stems and pretty, large, white and pink flowers with the hollow saccate lip typical of the V. chalotti group. Vanilla nigerica is different from $V$. seretii in its lip being provided with 2 gibbae at base, the coarsely hairy lip throat, and the recurved, not rolled midlobe of the lip. It is probably a rare plant. Collection: CAMEROON: Bates 1263 (BM!).

SourCES: Portères, R. 1954. Le Genre Vanilla et ses Espèces: 172; Summerhayes, V.S. 1968. Flora of West Tropical Africa 3(1): Orchidaceae: 205-206.

65. V. ochyrae Szlach. \& Olszewski in Fl. Cameroun 34: 291 (1998). Type: Cameroon, Jacques-Félix 4727 (holo. P!; iso. $\mathrm{K}$ !).

\section{Distribution: Cameroon.}

A species closely related to $V$. imperialis, but distinguished by it clearly trilobed lip, with a semiorbicular midlobe larger than the larger lateral lobes and the margins undulate. The lamellae and trichomes of the lip are branched.

COLLECTION: CAMEROON: Endenguele 113 (K!).

66. V. odorata C.Presl, Reliq. Haenk. 1(2): 101 (1830). Type: Ecuador, Haenke s.n. (holo. PR!; iso. PR!).

$V$. ensifolia Rolfe in Bull. Misc. Inform. Kew 1892(65/66): 141 (1892).Type: Colombia, Goudot s.n. (holo. K!).

V. uncinata Huber ex Hoehne in Arquiv. Inst. Biol. (S. Paulo) 8: 269 (1937). Type: Pará, Brazil, Goeldi 7392 (holo. MG!).

V. denticulata Pabst, 23 ${ }^{\text {rd }}$ Congr. Nac. Bot., Garanhuns: 109 (1972). Type: Brazil, Ferreira 37-67 (holo. HB).

Distribution: Mexico, Guatemala, Costa Rica, Panama, Colombia, Peru, Bolivia, Brazil.

Vanilla odorata is widely distributed in continental tropical America, from Mexico to Bolivia. It is easily distinguished by its narrowly lanceolate, long acuminate leaves; although specimens grown in shaded spots may have broader leaves. Its fruits are strongly fragrant and are collected from wild plants in many areas of Latin America. It is occasionally grown in Oaxaca, Mexico, as source of vanilla fragrance.

Vanilla denticulata and $V$. uncinata seem to be conspecific with it, their vegetative and floral dimensions falling within the known range of $V$. odorata, although the lip of $V$. uncinata is slightly emarginate. Vanilla fimbriata is also very closely related but the flowers are smaller. However, better 
and more abundant material from Amazonia and the Guyanas is necessary to be compared carefully with specimens of $V$. odorata from other areas.

Collections: BELIZE: Whitefoord 1316 (BM!). COSTA RICA: Standley \& Valerio 48917 (AMES!). GUATEMALA: Aguilar 164 (AMES!). PANAMA: Hunnewell 16433 (AMES!). COLOMBIA: Lehmann H.K. 1183 (K!). PERU: Killip \& Smith 29065 (AMES!); Williams 3161 (AMES!). BOLIVIA: White 1115, 1821 (AMES!); Spencer Moore 637a (BM!).

Sources: Portères, R. 1954. Le Genre Vanilla et ses Espèces: 243-245, fig. 110; Schweinfurth, C. 1958. Orchids of Peru I. Fieldiana: Botany 30: 43; Dodson, C.H. \& P.M. Dodson. 1980. Ic. Pl. Trop. pl. 353; Hamer, F. 1984. Ic. Pl. Trop. t. 1193; Dodson, C.H. \& H.H. Gentry. 1985. La Flora de Jauneche: 110, t. 44A; Garay, L.A. 1978. Flora of Ecuador. Orchidaceae 1: 49 , fig. 14 .

67. V. organensis Rolfe in J. Linn. Soc. Bot. 32: 452 (1896). Types: Brazil, Organ Mountains, Gardner 632 (lecto. K-LINDL!, here designated; isolecto. AMES 71366! G! K! W 19645!) Miers (syn. BM! K!); Near Rio de Janeiro, Glaziou 11620 (syn. K!) \& 14320 (syn. $\mathrm{K} !)$.

A membranaceous Vanilla which seems to be closely related and perhaps not distinct from $V$. parvifolia, except for its more ruffled tepals, a trait that is very variable in other membranaceous vanillas. $V$. edwallii and $V$. bertoniensis are allied, but both have a long acuminate lip.

Sources: Portères, R. 1954. Le Genre Vanilla et ses Espèces: 257, fig. 116; Pabst, G.F.J. 1966. As Orquídeas do Estado da Guanabara. Orquídea 28(26): 169-170.

68. V. oroana Dodson in Orquideologia 22(3): 210 (2003). Type: Ecuador, Prov. El Oro, $3.7 \mathrm{~km} \mathrm{~N}$ of junction of old and new roads from Piñas to Santa Rosa, 12 km west of Piñas, 1400 m, 19 Apr 1989, Dodson, Williams, Dressler, Whitten \& Embree 17951 (holo. AMES!; iso. $\mathrm{K}$ ! (sterile) MO!).

DistRIBUTION: Known only from the type collection in western Ecuador.

Vanilla oroana is a member of the membranaceous group. It is a large vine, flowering at apex up to 18 $\mathrm{m}$ tall, with a very long inflorescence bearing large foliaceous bracts up to $110 \times 65 \mathrm{~mm}$. The large flowers have contorted tepals and the lip is covered with papillae and the apex is 5-keeled. Its sepals and petals are green, and its lip white, with yellow-orange lamella on apical lobe. Its nearest relatives seem to be the members of the $V$. mexicana complex.

\section{V. ovalifolia Rolfe $=\boldsymbol{V}$. zanzibarica}

69. V. ovalis Blanco, Fl. Filip. 448 (1845). Type: Philippines, Mt Majaijai, Lilio, Azaola s.n. (not located).

Epidendrum vanilla sensu Blanco, Fl. Filip. (ed. 2) 643: (1837), non L.

V. majaijensis Blanco, loc.cit. 593 (1845).

V. philipinensis Rolfe in J. Linn. Soc. Bot. 32: 459

(1896). Type: Philippine Islands, without precise locality, Cuming 2132 (holo. K!; iso. BM!).

Distribution: The Philippines (Luzon, Mindanao, Leyte, Samar and Sibuyan Islands).

This is the only leafy Vanilla in the Phillippines. Its sepals and petals are greenish-cream and the lip is marked with purple lines. It is apparently related to V. platyphylla from Sulawesi and to the New Guinean species, but it is distinguished by its very hairy lip apex.

Collections: Cuming (K-LINDL!); Luzon, $M$. Perrotet s.n. (G 7889/103!); D.E. Elmer 16035 (BM! G 7889/110! K!); A.D.E. Elmer 9259 (BM! K!); H.G. Gutiérrez 78082 (K!); A. Loher 5420 (K!), 5421 (K!) 5422 (K!); J.S. Serrato s.n. (BM! K!); Irosin 16035 (BM!); Merrill 665 (BM! K!); Sibuyan, D.A. Madulid $6875(\mathrm{~K} !)$.

Sources: Ames, O. 1908. Orch. 2: 47 (as V. philippinensis); Merrill, 1914. Species Blancoana: 459; Portères, R. 1954. Le Genre Vanilla et ses Espèces: 182-183; Valmayor, H.L. 1984. Orchidiana Philippiniana 1: 322.

70. V. ovata Rolfe in J. Linn. Soc. Bot. 32: 451 (1896). Type: Guyana, Martin s.n. (holo. BM, tracing at K!).

Distribution: Venezuela and Guyana.

This is perhaps not different from $V$. mexicana. We have not located the type specimen, and the rough tracing at $\mathrm{K}$ is inadequate to be sure. Illustrations identified as $V$. mexicana from South America (e.g. Garay \& Dunsterville, 1959) have an unusually broad midlobe to the lip, and may deserve specific 
recognition. Another specimen illustrated by Hoehne (1945) and identified as $V$. ovata has very slender segments and narrow midlobe of the lip. We cannot be sure of the identity of the South American material until specimens have become available to us.

Collections: VENEZUELA: Delta Amacuro: cf. J.A. Steyermark 87393 (G 7889/130!).

SourCEs: Portères, R. 1954. Le Genre Vanilla et ses Espèces: 254 and 264; Dunsterville, G.C.K. \& L.A. Garay. 1959. Venezuelan Orchids Illustrated 1: 432; Hoehne, F.C.1945. Flora Brasilica t. 29.

71. V. palembanica Teijsm. \& Binn. in Natuurk Tijdschr. Ned. Indie 29: 243 (1867). Type: Sumatra, Teijsman (holo. L).

\section{Distribution: Sumatra.}

Another scarcely known species that could be related to $V$. abundiflora group.

Source: Portères, R. 1954. Le Genre Vanilla et ses Espèces: 167.

72. V. palmarum (Salz. ex Lindl.) Lindl., Gen. Sp. Orch. Pl. 436 (1840). Type: Brazil, Bahía, Salzmann s.n. (holo. K-LINDL! iso. K! G 78889/134! LE!).

Epidendrum palmarum Salzmann ex Lindl., Gen. Sp. Orchid. Pl. 436 (1840).

V. lutea C.H.Wright ex Griseb., Cat. Pl. Cub. 267 (1866). Type: Cuba, Wright s.n. (holo. BM?).

?V. lindmaniana Kraenzl. in Kongl. Svenska Vetenskapsakad. Handl. 46(10): 17 (1911). Type: Brazil, Matto Grosso, near Palmeiras, Exp. I Regnell, Lindman 2481 (holo. S).

Distribution: Brazil, Venezuela, Guyana, Suriname, Bolivia, Peru. Mostly in the Amazonian basin.

Vanilla palmarum is different from other American Vanilla species in lacking a penicillate callus on the lip, and in having its column united to the lip for only about a half of the column length. In other species the penicillate callus is necessary during the pollination, but $V$. palmarum seems to be autogamous. The inflorescence is rather lax, compared with other American vanillas. It forms infrutescences with many thick fruits with a conspicuous calyculus. Weak plants are sometimes confused with those of $V$. bicolor. It is repeatedly reported as growing on palms (Mauritia, Orbignya, Attelia, Scheelea, Syagrus), and can be very abundant. The mature fruits are apparently odour-less.
Vanilla lindmaniana has been treated as an obscure, doubtful species. However, its habitat, habit, wooly column, simple ecallose lip, and concolorous yellow flowers suggest strongly that it is conspecific with $V$. palmarum. Considering the published drawings, Vanilla palmarum is rather variable in the form of the lip.

Collections: SURINAME: Hostmann (K-LINDL!). BRAZIL:Alagoas, Gardner 1419(BM! K!). Maranhao, Vieira et al. 1545 (CEN 013782!). Tocantins, Walter et al. 405 (CEN 026289!). Bahia: Curran 402 (AMES!); Blanchet s.n. (G 7889/137,140!); Blanchet 139 (G 7889/138!); Vignier s.n. (G 7889/139!); Giacometti 878 (CEN 15182!). Goias, Walter et al. 4100 (CEN 32308, s.n.!), 4031 (CEN 32254!), 3698 (CEN 31844!), 2044 (CEN 024613!), 1274 (CEN 17061!) \& 973 (CEN 15626!). Mato Grosso, Prance \& Schaller 26301 (CEN 3407, s.n.!); Argent et al. 6349 (K!). Pernambuco, Ridley et al. (BM!) E. Menezes 18 (K!). Para, da Silva \& Santos 30 (MG!); da Silva et al. 1959 (MG!). Amazonas, Ribeiro et al. 1333, 1963 (K!). Acre, Prance et al. 7955 (K!). BOLIVIA: White 935 (AMES!), 1512 (AMES!), 2332 (AMES!) \& 2366 (AMES!); White s.n. (AMES 48244!)

SourCEs: Martius, F.P.,1896. Fl. Brasiliensis 3: pt. 4: 152. 1896; Portères, R. 1954. Le Genre Vanilla et ses Espèces: 260-261, fig. 117; Foldats, E. 1969. Flora de Venezuela. Orchidaceae I: 120-121, fig. 40. Dunsterville, G.C.K. \& L.A. Garay. 1976. Venezuelan Orchids Illustrated 6: 438-439. Dodson, C. \& R. Vázquez. 1989. Ic. Pl. Trop. II: t. 0395 (as $V$. chamissonis).

\section{V. parishii Rchb. f. $=\boldsymbol{V}$. aphylla}

73. V. parvifolia Barb. Rodr., Orch. Nov. 2: 271, pl. 36 (1881). Type: Brazil, Paraná Province, near Curitiba, Dec., Rodrigues s.n. (holo. RJ $\dagger$ )

V. perexilis Bertoni in An. Ci. Parag. ser. 1. 8: 8 (1910). Type: Paraguay, Puerto Bertoni, Bertoni 3631 (not seen).

Distribution: Paraguay and Brazil (Paraná).

Vanilla parvifolia has a number of closely related species that must be studied carefully when more material become available. It is distinguished from the closely related $V$. angustipetala (syn. $V$. rojasiana), by its broader petals, more defined trilobed lip lacking the papillae or warts on the disc. 
Johnson (unpublished manuscript) stated that $V$. perexilis is a small-flowered frorm of $V$. parvifolia.

Sources: Martius, F.P. 1896. Fl. Brasiliensis 3: pt. 4: 151, t. 33. 1896; Portères, R. 1954. Le Genre Vanilla et ses Espèces: 264-266, fig. 119; Johnson, A.E. (unpublished). Las especies argentinas del género Vanilla.

\section{$V$. pauciflora Dressler $=V$. trigonocarpa}

74. V. penicillata Garay \& Dunsterv., Venez. Orch. Ill. 3: 324 (1965). Type: Venezuela, Río Carrao, Dunsterville 787 (holo. AMES).

Distribution: Venezuela and Brazil.

This is the only leafless Vanilla found in the South America. It was described from a specimen with immature buds. Flowering material has larger flowers than those stated in the original description, with greenish-yellow sepals, white petals and a white lip with a yellow center $(\mathrm{DS}=57 \times 11 \mathrm{~mm}$; $\mathrm{LS}=57$ $\times 12 \mathrm{~mm}, \mathrm{P}=57 \times 11 \mathrm{~mm}, \mathrm{~L}=53 \times 32 \mathrm{~mm}$, column $=42 \mathrm{~mm}$ long; ovary $=30 \times 3 \mathrm{~mm}$ ). It differs from the Caribbean species by its larger flowers, lacking purplish markings, the very long trichomes on the apex of the lip (up to $1 \mathrm{~cm}$ long), and the laceratefimbriate lateral lobes of the lip. These features and the very long column suggest that it is probably not related to the other leafless American vanillas, but to V. ribeiroi, which also has reduced, xerophytic leaves. Vanilla penicillata grows in white sand areas and its stems are less than $5 \mathrm{~mm}$ thick.

Collections: VENEZUELA: Dunsterville 786 (K drawing!), 1372 (K published drawing!); Steyermark \& Bunting 102811 (AMES!). BRAZIL: Amazonas, Calderón, Monteiro \& Guedes 2675 (K!).

SourCES: Foldats, E. 1969. Flora de Venezuela. Orchidaceae I: 121, fig. 41.

\section{$V$. perexilis Bertoni $=\boldsymbol{V} \cdot$ parvifolia}

75. V. perrieri Schltr. in Repert. Sp. Nov. Regni Veg. 33: 114 (1924). Type: Madagascar, Ankarafantsiba, $H$. Perrier 1851 (holo. P!).

Distribution: Endemic to Madagascar.

This leafless Vanilla is similar to the $V$. madagascariensis complex, but it has yellow flowers with a dark brownish throat of the lip. Its closest relative is $V$. humblotii.
Source: Du Puy, D., P. Cribb, J. Bosser \& J. \& C. Hermans. 1999. The Orchids of Madagascar: 207-208, pl. 42A.

\section{V. pfaviana $\mathrm{Rchb} . \mathrm{f} .=\boldsymbol{V}$. inodora}

76. V. phaeantha Rchb. f. in Flora 48: 274 (1865). Type: Cuba, C. Wright 3351 (holo. W; iso. AMES 71001, mixed with cf. V. poitaei! BM (another specimen is $V$. cf. poiteai)! G 7889/109! K!).

Vanilla planifolia var. macrantha Grisebach, Cat. Pl. Cub. 267 (1866). Type: Cuba, Wright 3351 (holo. BM?).

Distribution: U.S.A. (Florida), Cuba, Jamaica, Lesser Antilles, Venezuela, Trinidad \& Tobago, Mexico (Yucatán).

A common leafy species in the Caribbean area. The oblong-elliptic, xerophytic, leaves are usually shorter than the internodes. The flowers are very large, with greenish tepals, and the lip is white with yellow stripes. It is related to $V$. bahiana, from Brazil. From the $V$. planifolia and $V$. odorata complexes can be distinguished by its not warty disc.

Collections: U.S.A.: Florida: Eaton 1129 (BM! K!). CUBA: Acuña, Correll \& Roig 18508 (AMES!); Singleton 862 (AMES!); Singleton s.n. (AMES!); Hodge \& Howard (AMES!); Jack 4775, 5474 (AMES!); Grey (AMES!); Alain \& Acuña 2321 (AMES!); Britton, Britton \& Cowell 9639 (AMES!). TRINIDAD \& TOBAGO: Rorer s.n. (AMES!); Britton \& Coker 555 (AMES!); Baker 14733 (K!). JAMAICA: Harris s.n. (BM!); Fawcett 2 (K!). ST. VINCENT: Guilding s.n. (K!); H.H. \& G.W. Smith $1336(\mathrm{~K} !)$.

SourCES: León, F.S.C. \& F.S.C. Alain. 1946. Flora de Cuba 1: 351; Portères, R. 1954 Le Genre Vanilla et ses Espèces: 242-243; Schultes, R.E. 1960. Native Orchids of Trinidad and Tobago: 40; Kenny, J. 1988. Native Orchids of the Eastern Caribbean: 23; Britton, N.L. \& C.F. Millspaug. 1962. The Bahama Flora: 83-84; Acuña, G.J. 1939. Catálogo Descritivo de las Orquídeas Cubanas: 22. Luer, C.L. 1975. Native Orchids of North America: 70, pl. 18.

77. V. phalaenopsis Rchb. f. ex van Houtte, Fl. Serres 17: 97, t. 1769-1770 (1867-1868). Type: Seychelles, Horne 607 (holo. $\mathrm{W}$ ! iso $\mathrm{K}$ !).

Distribution: Seychelles. 
This species is scarcely different from $V$. roscheri from continental Africa and the nearby islands. The appearence is exactly the same, however the base of the lip is said to be much more pubescent than in $V$. madagascariensis.

Collections: SEYCHELLES: Jeffrey s.n. (K photo!); Schlieben 16692 (K!); Thomasset s.n. (K!); Fosberg 51988 (K!); Moulinie \& Zelia 731 (K!); Jeffrey \& Zelia 375 (K!).

SourcE: Reichenbach, H.G. 1877. Orchidaea Roezlianae Novae. Linnaea 41: 65-67.

V. philippinensis $\operatorname{Rolfe}=\boldsymbol{V}$. ovalis

V. pierrei Gagnep. $=$ ?V. siamensis

V. pilifera Holttum $=\boldsymbol{V}$. borneensis

$V$. pittieri $\operatorname{Schltr.}=V$. pompona

78. V. planifolia G. Jackson in Andrews, Bot. Repos. 8: t. 538 (1808). Type: West Indies, cult. Greville (illustration cited here, lecto. selected by Garay, Fl. Less. Antill. 44. 1974).

Epidendrum rubrum Lam., Encycl. 1, 1: 178 (1783), nomen conf.

V. aromatica Willd. Sp. Pl. (ed. 4): 121 (1804), nomen.

Myrobroma fragrans Salisb., Parad. Lond. 2(1): t. 82 (1807). Type: Illustration cited here.

V. viridiflora Blume, Bijdr. 422 (1825). Type: Cult. Buitenzorg BG (holo. not seen).

V. sylvestris Schiede in Linnaea 4: 573 (1829).

Type: Mexico, Schiede s.n. (holo. BM!).

V. sativa Schiede in Linnaea 4: 573 (1829). Type:

Misantla, Schiede s.n. (iso. BM!).

V. duckei Huber, Bol. Mus. Paraense Hist. Nat. 5(2): 327 (1909). Types: Brazil, Amazonas, A. Ducke 3079 (syn. MG) \& 3489 (syn. MG).

V. domestica Druce, Rep. Bot. Exch. Club 3: 425. 1913 (1914).

V. rubra (Lam.) Urban in Repert. Sp. Nov. Regni Veg. Beih 5: 157 (1920), nomen conf.

V. fragrans (Salisb.) Ames, Sched. Orch. 7: 36 (1924).

V. bampsiana D. Geerinck in Bull. Jard. Bot. Belg. 52, 3-4: 345 (1982). Type: Zaire, Bikoro, Lac Leopold II, Sept. 1930, Lebrun 1459 (holo. BR!; iso. $\mathrm{K}$ !).

V. majaijensis Blanco, Fl. Filip. (ed. 2) 593 (1845).
Type. Philippines, Mt. Majaijai, Azaola s.n. (holo. not located).

Distribution: Native of Mexico, Guatemala, Belize, Honduras, Costa Rica, and Panama. Apparently escaped in Florida, Jamaica, Puerto Rico, Zaire and New Guinea, and perhaps in many other tropical areas.

This species is the cultivated source of the vanilla essence. Its natural range probably ran from Central Veracruz in Mexico to Costa Rica or Panama, but it is now found in many tropical areas as an escape. All the material we have seen from Africa, the West Indies, South America (including Ecuador), and most of Costa Rica and Panama, is indistinguishable from the cv. "Mansa" from Veracruz, and different from wild specimens from Chiapas, Belize and Honduras which have characteristically broad, elliptic leaves.

We have not examined the syntypes of $V$. duckei Huber, but follow Hoehne (1954) who considered it a synonym of $V$. planifolia. The material of $V$. carinata Rolfe is very inadequate, and we are not completely sure that it is conspecific with V. planifolia.

This species has several allies with which it can be confused, particularly V. hartii, V. insignis, V. odorata and $V$ tahitiensis (see comments under those species).

Collecrtions: MEXICO: Pavón (actually Sessé and Mociño) s.n. (G 7889/150!); without collector (G 7889/106!); Schott s.n. (BM!); Comisión GeográficoExploradora 7725 (AMES!); González in Oestlund 5790 (AMES!); Nagel in Oestlund 5001 (AMES!); Nagel in Oestlund 5050 (AMES!). GUATEMALA: Lehmann 1436 (BM!); Standley 25064 (AMES!); Johnson 1178 (AMES!). BELIZE: Gentle 2894 (K!); Schipp S-971 (AMES!). HONDURAS: Standley 55583 (AMES!); Yuncker 4993 (AMES!). COSTA RICA: Brenes 690 (F!); von Wedel 1529 (BM!); Standley \& Valerio 48904 (AMES!). PANAMA: Standley 29103 (AMES! sterile); Standley 29731 (AMES! sterile); Proctor 287 (AMES!). Sources: Portères, R. 1954. Le Genre Vanilla et ses Espèces: 234-239, fig. 108; Garay, L.A. 1978. Flora of Ecuador. Orchidaceae I: 49-52, fig. 15; Dodson, C.H. \& P.M.. 1980. Ic. Pl. Trop. pl. 354; Hamer, F. 1984. Ic. Pl. Trop. pl. 1194; Dodson, C.H. \& H.H. Gentry. 1985. La Flora de Jauneche: 110, pl. 44-B; Castillo Mayda, M. \& J.D. Ackerman. 1992. The Orchids of Puerto Rico and the Virgin Islands: 54, pl. 11; Ackerman, J.D. 1995. An Orchid Flora of Puerto Rico and the Virgin Islands: 176, fug. 96. 
V. planifolia var. gigantea Hoehne $=\boldsymbol{V}$. hostmanii

V. planifolia var. macrantha Griseb. $=$ V. phaeantha

Sources: Gloudon, A. \& Tobisch, C. 1995. Orchids of Jamaica.: 207-208. Foldats, E. 1969. Flora de Venezuela. Orchidaceae I: 123, fig. 42 (this drawing may be based on a different species); Dodson, C.H. \& Gentry, H.H. 1985. La Flora de Jauneche: 110, pl. 44-B.

79. V. platyphylla Schltr. in Repert. Sp. Nov. Regni Veg. 10: 7 (1911). Type: Sulawesi, Gunong Klabat, c. 400 m, 13 Dec. 1909, Schlechter 20556 (holo. B†; iso. $\mathrm{K}$ !).

Distribution: Endemic to Sulawesi.

This poorly known species has the vegetative aspect of $V$. kinabaluensis; the inflorescence, although truncate in the type, seems to be many-flowered. Also the large, thick capsule and the form of the buds are reminiscent of $V$. kinabaluensis. An illustration of a floral dissection is provided by Mansfeld (1934).

SourCEs: Portères, R. 1954. Le Genre Vanilla et ses Espèces: 213; Mansfeld, R. 1934. Repert. Sp. Nov. Regni Veg. 74: t. 14.

V. pleei Portères in Bull. Soc. Bot. France 58: 94 (1951). Type: Ile de la Martinique, Plée 621 (holo. P).

Garay \& Sweet (1974) suspected that this species was based on a mixed collection apparently containing the leaves of $V$. mexicana and the flowers of $V$. pompona or of an allied species.

Sources: Portères, R. 1954. Le Genre Vanilla et ses Espèces: 262; Garay, L.A. \& H.R. Sweet. 1974. Flora of the Lesser Antilles. Orchidaceae: 46.

80. V. poiteai Rchb. f. in Linnaea 41: 66 (1877). Type: Santo Domingo, Poiteau s.n. (holo. W 19346!).

V. aphylla sensu Eggers in Vidensk. Meddel Dansk Naturhist. Foren. Kjoebenhavn 21 (1889), non Blume (1825). Type: Santo Domingo, Llanos de Rafael, 200 m, 7 June 1887, Eggers 1958 (iso. K! sterile; G 7889/172! sterile).

V. eggersii Rolfe in J. Linn. Soc. Bot. 32: 472 (1896). Based on V. aphylla Eggers.

V. correllii Sauleda \& R.M. Adams in Brittonia 33(2): 192 (1981). Type: Bahama Islands, Grand Bahama, Freeport Hammock, off Coral Road, Correll, Popenoe \& Fluck 45441 (holo. NY; iso. FTG).
Distribution: Bahamas, Cuba, Hispaniola, and Puerto Rico.

This is a "leafless" American Vanilla, in which small, hooked leaves are present at each node. It has a large flabellate lip with a recurved apical lobe and an irregular, crisped and maroon margin. The identity of this species has been recently solved by Ackerman (1995) who studied all the leafless Caribbean vanillas. Collections: DOMINICAN REPUBLIC: Fuertes 912 (BM! K!); Wright 3351 (BM! AMES!, K! sterile; formerly mixed with the isotype of $V$. phaeantha). PUERTO RICO: Garber 20 (K! fruits only).

SOURCE: Ackerman, J.D. 1995. An Orchid Flora of Puerto Rico and the Virgin Islands: 169-171, fig. 92.

81. V. polylepis Summerh. in Bot. Mus. Leafl. 14: 219 (1951). Type: Northern Rhodesia (Zambia): Mwinilunga District, River Matonchi, 23-24 Oct. 1937, Milne-Redhead 2930 (holo. K!; iso. K!).

V. schliebenii Mansf. ex Schlieben in Gartenflora, 1937: 86: 42, 43, 58 (1937), nomen. Based on: Tanzania, Schlieben 1422 (G!; Z!).

Distribution: Kenya, Tanzania, Zambia, Malawi, Democratic Republic of the Congo, Zimbawe, Angola, Uganda.

A species closely related to $V$. imperialis, differing by its notched lip, shorter, broader tepals, lip with several rows of transverse, branching scales (not fine hairs), and a purple-violet blotch on lip, rather than a lip marked with streaks.

Collections: D.R. CONGO: Seighita 3570 (BR, $\mathrm{K}$ !); Rogers 148 (BM! K!); van Hirschberg 28 (K!). KENYA: Verdcourt 1011 (K!); Piers 75 (K!, drawing),; 19527 (K!). TANZANIA: Burtt 18136 (BM!); Petterson 3-a (K!). ZAMBIA: MilneReadhead 4265 (K!); Richards 2026, 15355, 20509 (K!); Morze 126A, 126B (K!); Bredo in Moreau 864, 864A, 864B, 867 (K!); Fanshawe 2545 (K!),; 9660 (K!); Stevenson 1653 (K!); Holmes 0137 (K!); Burtt 6338 (K!); Harder et al. 2044 (K!). MALAWI: La Croix et al. 880 (K!); Pawek 1020 (K!). ZIMBAWE: Ball 844 (K!); Chase s.n., 3896 (K! BM!),; 4307 (K! $\mathrm{BM} !) ; 4680$ (K!, pictures; $\mathrm{BM} !) ;$ Renz et al. 11344 (K!); Flowers 2667 (K!).

Sources: Portères, R. 1954. Le Genre Vanilla et ses Espèces: 202-203; Stewart, J. \& Campbell. 1970. Orch. Trop. Afr.: 114, t. 45; Hunt, P.F., 1974. K.B. 29: 
425; Stewart, J. 1974. Upland Kenya Wild Flowers: 756; Williamson, G. 1977. Orchids of South Central Africa: 146, fig. 78, t. 124; Cribb, P. 1984. Flora of Tropical East Africa. Orchidaceae 2: 261, fig. 51; Geerinck, D. 1984. Flore D'Afrique Centrale (Zaire, Rwanda-Burundi): 243-244; Stewart, J. 1996. Orchids of Kenya: 89-90; Szlachetko, D.L. \& S. Olszewski. 1999. Fl. de Cameroun: 288, pl. 102, I-M.

82. V. pompona Schiede in Linnaea 4: 573 (1829). Type: Mexico, Schiede 1043 (lecto. BM!, designated by Garay, Fl. Ecuador Orch. 1:52. 1978; isolecto. K! LE! P! W!).

V. pittieri Schltr. in Repert. Spec. Nov. Regni Veg. 3: 106 (1906). Type: Costa Rica, Pittier 6600 (holo. B $\dagger$; trace at AMES 24329!).

Distribution: Mexico, Nicaragua, Costa Rica, and probably W Colombia and Ecuador.

Vanilla pompona is a variable, widely distributed species. We consider it to be a species complex. The specific name is based on a Mexican specimen collected in central Veracruz. Mexican populations are apparently isolated from the rest of the populations of the species because there are no known populations in Chiapas, Guatemala, Belize, or El Salvador. It reappears only in Central Honduras and Nicaragua. Collections: MEXICO: without precise locality, Sallé (BM!). Michoacan, Hinton et al. 13815 (AMES!); 15910 (AMES!). Guerrero, Langlassé 941 (AMES! G 7889/153! 154! K!); Hinton 11387 (K!). OAXACA: Cuming s.n. (G 78889/155!); Nagel in Oestlund 4574 (AMES!); Copalita, Nagel \& González in Oestlund 6102 (AMES!); Veracruz, Bourgeau 2232 (K!); Nagel in Oestlund 2684 (AMES!). COSTA RICA: Alfaro 269 (AMES!). COLOMBIA: Smith 2370 (K!) \& 2371 (AMES! K!).

Sources: Portères, R. 1954. Le Genre Vanilla et ses Espèces: 223-226, fig. 102 and 234 (as V. pittieri); Garay, L.A. 1978. Flora of Ecuador. Orchidaceae I: 52, fig. 16; Hamer, F. 1984. Ic. Pl. Trop. t. 1195; McVaugh, R. 1985. Flora Novo-Galiciana 16: Orchidaceae: 351-353, fig. 115; Ackerman. J.D. 1995. An Orchid Flora of Puerto Rico and the Virgin Islands: 174-176; Pupulin, F. 1998. Orchid Florula of Parque Nacional Manuel Antonio, Quepos, Costa Rica. Rev. Biol. Trop. 46(4): 1029.
V. ponapensis Kaneh. \& K.Yaman. = Pseudovanilla ponapensis (Kaneh. \& K.Yamam.) Garay.

$V$. porteresiana Veyret \& Szlach. $=\boldsymbol{V}$. hostmanii

$V$. preussii Kraenzl. $=\boldsymbol{V}$. inodora

83. V. pseudopompona Soto Arenas, ined.

Distribution: Panama.

This species is very near to $V$. pompona, but it has smaller, narrower leaves, and flowers with a much larger penicillate callus.

Collections: PANAMA: Seeman 1159 (BM! K-L!); Allen 4428 (G 7889/121!); Hunter \& Allen 852 (AMES! G7889/151!); Powell 137 (AMES! BM!); Powell 3507 (AMES!); Maxon 6779 (AMES!); Standley 29919 (AMES!); Bangham 458 (AMES!); Piper s.n. (AMES!).

$V$. pterosperma Wall. ex Lindl. = Galeola hydra

V. purusara Barb. Rodr. ex Hoehne $=\boldsymbol{V}$. appendiculata

84. V. ramificans (J.J. Sm.) J.J.Sm. in Bull. Jard. Bot. Buitenzorg ser. 3, 2: 22 (1920). Based on same type as V. ramosa J.J.Sm.

V. ramosa J.J.Sm. in Repert. Sp. Nov. Regni Veg. 11: 130 (1912), non Rolfe. Type: New Guinea, Papua (Dutch New Guinea), Jayapura (Hollandia), Gjellerup 706 (holo. L).

Distribution: New Guinea: Irian Jaya and Papua New Guinea, in the Southern Highlands Province and on Normanby Island.

The small leaves $(100-130 \times 25-40 \mathrm{~mm})$ and the branched inflorescence are characteristic among the New Guinean species. The cream and red flowers and the many-flowered inflorescence suggest a relationship with the $V$. kinabaluensis complex. We have examined specimens cultivated in the National Botanic Gardens, Papua New Guinea which correspond well with the published drawings and share with other New Guinean species the very thick ovaries

Collection: PAPUA NEW GUINEA: Lelean \& Streimann LAE 52525 (K!).

SourCES: Smith, J.J. 1915. Die Orchideen von Niederländisch-Neu-Guinea: $\quad 187, \quad$ t. $\quad 62, \quad 100$; Portères, R. 1954. Le Genre Vanilla et ses Espèces: 210; Howcroft, N.H.S. 1984. A Guide to the monocotyledons of Papua New Guinea. R.J. Johns 
\& Hay, A.J.M. (eds.) 4. The Orchidaceae (in part): Forestry Department PNG, University of Technology. p. 126, fig. 74; O’Byrne, P. 1994. Lowland Orchids of Papua New Guinea. SNP Ltd. p. 9.

85. V. ramosa Rolfe in J. Linn. Soc. Bot. 32: 457 (1896). Types: West Tropical Africa, Niger, about Angiama, Barter 20134 (lecto. K! selected by Geerinck, 1984); interior of Western Lagos, Rowland s.n. (syn. K!).

V. ovalifolia Rolfe in J. Linn. Soc. Bot. 32: 457 (1896). Type: West Tropical Africa, Old Calabar, Thomson 132 (holo. K!).

V. laurentiana De Wild, Not. Pl. Utiles Congo, 1: 327 (1903). Type: Zaire, Nala, 1903, van Rysselberghe 5 (holo. BR, iso. K!).

$V$. africana Lindl. var. laurentiana (De Wild.) Portères in Bull. Soc. Bot. France 98: 126 (1951).

V. laurentiana De Wild. var. gilletii De Wild., loc. cit. 325 (1951). Type: Zaire: between Kisatu and Kimpasa, Collet 3362 (holo. BR; iso. K!).

V. africana Lindl. subsp. ramosa (RolfeSzlach. \& Olszewski in Fl. Cameroun 34: 286 (1988).

Distribution: Ghana, Nigeria, Cameroon, Equatorial Guinea, Gabon, Congo, Democratic Republic of the Congo and Central African Republic. The reports from Eastern Africa are here considered as V. zanzibarica.

Vanilla ramosa is a member of the $V$. africana complex in which the inflorescences are usually branched, the oblong-elliptic leaves are much broader, and the midlobe of the lip is oblong-elliptic and apiculate-acuminate. In living condition the lip is rather flat, rather than conduplicate-gibbose as in $V$. crenulata which also has large, broad lower bracts in the simple raceme. Some authors (e.g. Geerinck, 1984) have treated $V$. ramosa as synonym of $V$. crenulata, but it differs in the conduplicate-gibbose lip of $V$. crenulata, in its broadly elliptic to suborbicular lower bracts of the inflorescence and in its larger lip measurements.

Collections: GHANA: Bowling 36647 (K!); Irvine 2197 (K!); Andoh FH 5257 (K!). NIGERIA: Talbot s.n. (K!); Kennedy 220, 2081 (K!). CAMEROON: Bates 1117 (BM!); Zenker 1127 (BM! K!) \& 3010a (BM! K!); Thomas 5922 (K!); Binuyo \& Daramola FHI 35648 (K!); Leeuwenberg 5465 (K!). GABON: Le Testu 863 (BM!), 7723 (BM! K!), 9015 (BM! K!);
Tisserant 1575 (BM!). D.R. CONGO: De Giorgi 1715 (AMES! BM! K!); Louis 8577 (BM!); Vermoesen 1869 (K!); Lebrun 1948 (K!); Germain 4520 (K!); Lebrun 2493 (K!). EQUATORIAL GUINEA: Tessmann 224 (K!). WITHOUT LOCALITY: Kew spirit collection 45787 (K!).

Sources: Portères, R. 1954. Le Genre Vanilla et ses Espèces: 198-200, fig. 93; Geerinck. 1984. Flore D'Afrique Centrale (Zaire, Rwanda-Burundi): 239242; Summerhayes, V.S. 1968. Flora of West Tropical Africa 3(1): Orchidaceae: 205-206; Szlachetko, D.L. \& S. Olszewski. 1988. Fl. Cameroun 34: 286.

\section{V. ramosa J.J. Sm. = V. ramificans}

86. V. ribeiroi Hoehne, Comm. Lin. Telegr., Bot. 1: 28 (1910). Type: Brazil, Matto Grosso, by Rio Jaurú, near Praxedes, Nov. 1908, Ribeiro in Hoehne 997 (holo. RJ 2512!).

Distribution: Brazil, Guyana, and Amazonian Colombia.

This species has white flowers and a lip adorned with conspicuous apical, retrorse, yellow trichomes. The lip covered with hairs is reminiscent of that of the Central American $V$. helleri, which has a more trilobed lip and broader leaves; in $V$. ribeiroi the leaves are very short and narrow.

Collections: COLOMBIA: Schultes \& Cabrera 15961 (AMES!). GUYANA: Jansen-Jacobs et al. $2524(\mathrm{~K} !)$.

Source: Portères, R. 1954. Le Genre Vanilla et ses Espèces: $185-186$

\section{V. ronoensis Hayata $=\boldsymbol{V}$. somai}

87. V. roscheri Rchb. f. in Linnaea 41: 65 (1877). Type: Tanzania, Zanzibar, 1851, Roscher s.n. (holo. W 19388! W 19389! drawings; K! tracing of W specimen).

Distribution: Ethiopia, Kenya, Somalia, Tanzania (including Zanzibar and Pemba), Mozambique, South Africa.

This leafless vanilla has spectacular white flowers with an apricot or pale pink throat to the lip, petals which are very broad and a lip with a somewhat undulate margin. It is very closely related to $V$. madagascariensis and V. phalaenopsis from the Seychelles; if they are considered conspecific, the 
correct name for the species is $V$. phalaenopsis, the oldest epithet.

Vanilla roscheri is common in tropical deciduous coastal forests of Kenya and Tanzania, and it is occasionally cultivated as ornamental. It has been only recently recorded from near Lake Sibaya in South Africa.

Collections: KENYA: Bally 8144 (K! K photos!), B10462 (G 7889! K!), 8540 (K!); Verdcourt 1195, 3223 (both K!); Brenan et al. 14549 (K!); Faden \& Evans 70/781 (K!); Polhill \& Paulo 876, 972 (K!); Napper 1468 (K!); Tweedie 1217 (K!), 1260 (K!); Drummond \& Hemsley 4118 (K!); Graham 1605 (K!); Greenway s.n. (K!), 9487 (K!); Perdue \& Kibuva 10125 (K!). TANZANIA: Greenway \& Turner s.n. (K photo!); Greenway 12455 (K!), Moreau 134 (K!); 134 A (K!); Archbold 2786 (K!); Richards 21992 (K!); Franzier 1185 (K!); Vaugham 2530, 2703, 2785 (all $\mathrm{K}$ !); Greenway 4125 (K!); Tanner 2453 (K!); Cribb \& Grey-Wilson 10013 (K!); Mwasumbi \& Khero 11000 (K!); Curle 442 (BM!); Pemba, Lambu s.n. (K!); Vaughan 937 (K!); Zanzibar, Kirk 3/701 (K!, 3/78 K! drawing); Lyne 4 (K!); Greenway $1315(\mathrm{~K} !), 2669$ (K!); Wigg s.n. (K!); Burt 2626, 2628 (K!); Vaugham 45 (BM!), 1662, 2153, 2173 (all K!). SOUTH AFRICA: C.J. \& M.C. Ward 59 (K! NH), 338 (K!). MOZAMBIQUE: Janson 7492 (K!); Danitree s.n. (K!); de Koning \& Hiemstre 8990 (K!); Ball 934 (K!); Gómez \& Sousa 4908 (K!); Grandvaux B 7724 (K!); Ball 1000 (K!); Watmough 351 (K!); Greenamdijk $\&$ de Koning 316 (K!); W.E. Taylor s.n. (BM!); Scott Elliot 6132 (BM!).

Sources: Rolfe, R.A. 1897. Fl. Trop. Afr. 7: 179; Piers, F. 1959. Orch. E. Afr.: 50 \& 1968. ed. 2: 82, fig. 29; Tweedie, E.M. 1964, J. E. Afr. Nat. Hist. Soc. 24: 41; Cribb, P. 1984. Flora of Tropical East Africa. Orchidaceae 2: 258-259, fig. 260; Stewart, J. 1996. Orchids of Kenya: 90; Linder, H.P. \& H. Kurzweil. 1999. Orchids of Southern Africa: 350-351.

\section{V. rubiginosa Griff. $=$ ? Galeola hydra \\ V. rubra (Lam.) Urb. $=$ ?V. planifolia}

88. V. ruiziana Klotzsch in Bot. Zeitung (Berlin) 4: 563 (1846). Type: Peru, Chicoplaya, Ruiz \& Pavón (holo. B †; iso. AMES 38626! and photo, G 7889/ 167 ! F!; tracing K! BM! G 158!).

V. weberbaueriana Kraenzl. in Bot. Jahrb. Syst.
37: 395 (1906). Type: Peru, Prov. Tarma, Dep. Junin, near la Merced, Chanchamayotal, $1000 \mathrm{~m}$, M. Weberbauer 1849 (? 18348) (holo. B†, AMES 38631 photo! iso. MOL!).

Distribution: Peru and Bolivia.

The identity of $V$. ruiziana has remained obscure since its publication in 1846 . The holotype specimen, lost when the Berlin Herbarium was destroyed, was sterile, having stout stems and acute to acuminate, lanceolate-oblong leaves. However, at least a duplicate of the same collection ("247 Epidendrum lanceolatum, vaynilla vulgo, folium cum caule, et flor" in Ruiz \& Pavón handscript, and annotated "M. Pavón”, perhaps in Reichenbach's hand) has been found in Geneva (G 7889/167)! The flowers are relatively poorly preserved, but it is possible to appreciate its granulose sepals and ovary surface, the thickened veins of the lip and the acute, strongly subcalyptrate sepals. This combination of characters is exclusive to the modern specimens from Peru and Bolivia. The type specimen of $V$. weberbaueriana, although bearing only young buds, also belongs here.

Leaf shape differences between the types of $V$. ruiziana and $V$. weberbaueriana seem striking, but there are intermediate specimens connecting both extremes. The vegetative parts of $V$. ruiziana seem to be taken from a shaded spot.

Portères (1954) assigned V. weberbaueriana to subsection Membranacea (= subsect. Vanilla). The study of more abundant material shows that $V$. ruiziana is closely related to $V$. hostmanii, differing mostly in its shorter inflorescences, the tepals which are acute, the sepals conspicuously calyptrate and a larger, ovate midlobe to the lip which bears 1-3 elevated, axial keels near the apex,

Collections: BOLIVIA: White 2326 (AMES!). PERU: Killip \& Smith 27430 (AMES!); Rubio Kayap 223 (MO 2922173!).

Sources: Portères, R. 1954. Le Genre Vanilla et ses Espèces: 233 and 253-254; Schweinfurth, C. 1958. Orchids of Peru I. Fieldiana: Botany 30: 44.

V. sativa Schiede $=\boldsymbol{V}$. planifolia

89. V. savannarum Britt. in Mem. Torr. Bot. Club 16: 61 (1920). Type: Cuba, near Camagüey, Britton \& Cowell 13210 (not seen) 
Distribution: Cuba.

Well-preserved flowers of this species are unknown to us. However, old flowers and dissected buds show a very close relationship with the South American $V$. palmarum, and these species must be compared carefully to determine if they are distinct. With Vanilla palmarum, it shares the similar habit and habitat, the lack of a penicillate callus, the presence of 5-6 axial, shortly pubescent lines on the distal half of the lip, the long lanuginose area beneath the stigma, and the lip fused to the column for only about a half of the column length. The densely-fruited raceme and the pods with a well-developed calyculus are also similar. The many fruits per inflorescence suggest self-pollination.

Collections: CUBA: Gonzáles 288 (AMES!); Clemente \& Alain 1050 (AMES!); Schaffer 615 (para. AMES!), \& 1072 (para. AMES! K!); Ekman 19043.

Sources: Acuña, G.J. 1939. Catálogo Descriptivo de las Orquídeas Cubanas: 21-22; León, F.S.C. \& F.S.C. Alain. 1946. Flora de Cuba 1: 352, fig. 147.

\section{$V$. schliebenii Summerh. $=\boldsymbol{V}$. polylepis}

90. V. schwackeana Hoehne in Arq. Bot. Estado São Paulo 1: 125. t. 135 (1944). Type: Brazil, Minas Gerais, Schwacke 11106 (holo. RJ 37015!).

This species seems to be related to $V$. cristagalli, but the ornamentation on the lip is much reduced to warty, apical papillae. Hoehne (1944) indicated that the specimen could be a mixture of parts of different species, the leaves being very long acuminate, and thin. Specimens collected in Amazonia (J.B.F. $d a$ Silva 590, MG!) have flowers indistinguishable from those of the type of $V$. schwackeana, but with thick, coriaceous, oblong-elliptic leaves with recurved margins, suggesting that Hoehne's doubts about the mixture nature of the type specimen had substance.

Collections: BRAZIL: PARA: da Silva 590 (MG!), 591 (AMO! sterile).

91. V. seranica J.J. Sm. in Bull. Jard. Bot. Buitenzorg ser. 3, 10: 93 (1928). Types: Moluccas, Ceram, Rutten $1800 \& 1880$ (syn. L).

Distribution: E Indonesia, Moluccas.

Said to be allied to $V$. abundiflora and $V$. klabatensis.
SOURCE: Portères, R. 1954. Le Genre Vanilla et ses Espèces: 215.

92. V. seretii De Wild. in Bull. Jard. Bot. État 5(2): 180 (1916). Types: Zaire, near Nala, 1907, Seret 756 (syn. BR); near Arebi, 1906, Seret 714; Nala (syn. BR); 1911, Boone 111 (syn. BR); Libenge, 1913, Mestdagh 59 (syn. BR; isosyn. BM!).

V. tisserantii Portères in Bull. Soc. Bot. France 98: 93 (1951). Type: Central African Republic (French Equatorial Africa), Bukoko, Oubangui, SW of Bangui, 18 Aug. 1947, Tisserant 151 (holo. P; iso. BM! G!).

Distribution: Democratic Republic of the Congo and Central African Republic.

This is another member of the $V$. chalotii group, in which the lip is deeply saccate. It is distinguished from $V$. nigerica by its lip in which the throat has few hairs and lacks a gibbous base.

Collection: D.R. Congo: H. Callens 906 (K!).

Sources: Portères, R. 1954. Le Genre Vanilla et ses Espèces: 172-174, fig. 83 (as V. tisserantii); Szlachetko, D.L. \& S. Olszewski. 1999. Fl. de Cameroun: 288, t. 102, A-H.

Vanilla shenzhenica Z.J. Liu \& S.C. Chen $=$ V. somai

93. V. siamensis Rolfe ex Downie in Bull. Misc. Inf. Kew 1925(10): 410-411 (1925). Type: Thailand, Doi Sutep, 690 m, Kerr 95 (holo. K!; iso. C!).

V. pierrei Gagnep. in Bull. Mus. Hist. Nat. (Paris) 3: 686 (1931). Types: Cambodia, Mts Kamchay, Prov. Kampot, Pierre 1560 (syn. P); Cambodia (Cochinchina), Mts Binh-dinh, Pierre s.n. (syn. P).

Distribution: Thailand, Kampuchea (Cambodia), Vietnam, China (Yunnan).

This species is characterized by its large, broadly elliptic or ovate, shortly apiculate leaves. The large flowers have very long, flat papillae at the lip apex. It is similar to $V$. abundiflora and $V$. kinabaluensis.

We here consider $V$. pierrei to be conspecific. It was described from immature buds, but the general appearence is the same as $V$. siamensis. However, we would like to compare better material of $V$. pierrei with that of $V$. siamensis. Vanilla siamensis is a montane species found from 700 to $1300 \mathrm{~m}$ elevation.

Collections: THAILAND: $R$. Geesink et al. 6755 (K!), 6698 (K!); without collector 38 (K! sterile). 
Sources: Gagnepain, F. \& A. Guillaumin. 1932. Flore Genérale de L'Indo-Chine 2. Orchidacées: 582-584, fig. 55 10-13; Portères, R. 1954. Le Genre Vanilla et ses Espèces: 210-212, fig. 98 and 218-219, fig. 101 (as V. pierrei); Seidenfaden, G. \& T. Smitinand. 1959. The Orchids of Thailand: a preliminary list, part 1 : 60, fig. 41; Averyanov, L. 1988. Predvaritelnyt spisok orkhidnykh: 112 (as V. pierrei); Averyanov, L.V. 1994. Identification Guide to Vietnamese Orchids: 76 (as $V$. siamensis); Chen; S., Z. Tsi \& Y. Luo. 1999. Native Orchids of China. Science Press, Beijing: 411.

94. V. somai Hayata, Ic. Pl. Formosan. 6: 88, t. 14 (1916). Type: TaIwan, between Urai and Agisku, May 1916, Hayata s.n. (holo. TI).

Vanilla griffithii sensu Hayata in J. Coll. Sci. Imp. Univ. Tokyo 30, 1: 343 (1911), non Rchb. f. (1854).

Vanilla griffithii Rchb. f. var. formosana Ito, Icon. Pl. Japan. 1(4): 1 t. 1 (1911).

Vanilla ronoensis Hayata, Icon. Pl. Formosan. 9: 114 (1920). Type: Taiwan, between Rono and Kosenpo, April 1917, Hayata s.n. (holo. TI).

Vanilla griffithii Rchb. f. var. ronoensis (Hayata) S.S. Ying, Col. Illustr. Indig. Orch. Taiwan, 1(2): 509 (1977).

Vanilla albida sensu H. J. Su in Huang, T.S. et al. (eds), Flora of Taiwan 5: 1065 (2000), non Blume (1823).

Vanilla shenzhenica Z.J. Liu \& S.C. Chen in Acta Phytotax. Sinica 45, 3: 301 (2007). Type: China, Guangdong, Shenzhen, Longgang, Meishajian, 22 Feb 2005, Liu 3025 (holo. NOCC).

Distribution: Taiwan, Vietnam, and China.

The rather small flowers with a short tube, the high, flattened papillae arranged in two rows at the lip apex, and the inflorescences with two flowers open simultaneously are characteristic. Its inflorescence structure is similar to that of $V$. annamica, but in that species the inflorescence is much branched, and the flowers less than half the size.

Collections: CHINA: Guangdong, Liu 3025 (NOCC!). TAIWAN: Price 302 (K!), 302 bis (K!); Henry 479 (K!).

Sources: Hayata, B. 1911. J. Col. Sci. Univ. Tokyo 30(1): 342 (as V. griffithii); Portères, R. 1954. Le Genre Vanilla et ses Espèces: 183 (as V. ronoensis) and 184-
185, fig. 87; Su, H.J. 1985. Native Orchids of Taiwan. pl. 50: 54-1 (as V. griffithii); Ying, S.S. 1977. Coloured Illustrations of Indigenous Orchids of Taiwan 1: 338340, pl. 339 (as V. griffithii var. formosana); Chow Cheng. 1989. Formosan Orchids. Epiphytes: 204-206 (as V. albida); Tsan-Piao Lin. 1975. Native Orchids of Taiwan: 248-249.

V. speciosa Boxall ex Neves, in Blanco, Fl. Philipp. de. III. Nov. App. 248, nomen.

95. V. sprucei Rolfe in J. Linn. Soc. Bot. 32: 461 (1896). Type: Colombia, R. Vaupés, Nov. 1852, Spruce 2727 (holo. K-LINDL!).

Distribution: Amazonian Colombia.

This species is rather mesophytic, the type having slender stems, drying almost black, and thin leaves covered with epiphylls. The parallel veins and transverse secondary veins of the leaves resemble those of Epistephium leaves. The raceme is lax with about 4 to 8 (perhaps more) successive whitishgreen flowers with very narrow tepals and a very long tubular lip with a conspicuous penicillate callus. The flowers seem to develop over a long period, and small, undeveloped buds are present when one flower is in anthesis, perhaps in the way described for $V$. pauciflora, to which might be related. Schultes \& Cabrera 12497 has inflorescences branched at base, very odd for American species. A calyculus is scarcely present.

Collection: COLOMBIA: Schultes \& Cabrera 12497 (AMES!).

Source: Portères, R. 1954. Le Genre Vanilla et ses Espèces: 247.

96. V. sumatrana J.J. Sm. in Bull. Jard. Bot. Buitenzorg, ser. 3, 2: 22 (1920). Type: Sumatra, Benkoelen, Bukit Barisan, Rimbo-Pengadang, 1000 m, June 1916, Jacobson \& Ajaeb 210 (L not seen).

Distribution: Sumatra.

A little known species which, in the protologue, was compared with $V$. griffithii Rchb. f., but differs in the narrowly spathulate sepals and petals, the small shortly bilobed but not flabellate midlobe of the lip, the series of transverse lamellae beneath the hair cushion, and the different anther. It has a reddish lip. It is found at higher elevations, more than $1000 \mathrm{~m}$, than V. griffithii. 
Sources: Carr, C.E. 1935. Two Collections of Orchids from British North Borneo 1. Gard. Bull. Straits Settlements: 8: 176; Portères, R. 1954. Le Genre Vanilla et ses Espèces: 216-218, fig. 100.

\section{V. surinamensis $\mathrm{Rchb} . \mathrm{f} .=\boldsymbol{V}$. guianensis}

97. V. tahitensis J.W. Moore in Bull. Bernice P. Bishop Mus. 102: 25 (1933). Type: Society Islands, Raiatea, Moore 294 (holo. BISH!).

V. tiarei Costantin \& Bois in Compt. Rend. 161: 201 (1915), nomen nudum.

V. hirsuta M.A. Clem. \& D.L. Jones in Lasianthera 1(1): 47 (1996). Type: Papua New Guinea, Clements 6742 (holo. CANB; iso. NCBG).

V. tahitensis var. haapape Portères, Bull. Soc. Bot. France 98:127 (1951), nomen nudum. Based upon: cult.. Tahiti, without further provenance.

V. tahitensis var. potiti Portères, Bull. Soc. Bot. France 98: 127 (1951), nomen nudum. Type: cult. Tahiti, 1926, without further provenance.

Vanilla tahitiensis is the second most important vanilla for production of aromatic pods. It is closely related to $V$. planifolia and $V$. odorata and a member of the American clade of the genus with penicillate callus. Its distribution in the South Pacific Islands is striking, and it is very probable that it is a hybrid distributed originally from the Philippines and taken to its present area by man. A good drawing of it is provided by Howcroft (1984). The Tahitian vanilla is a probably a hybrid between Vanilla odorata and $V$. planifolia. Five varieties are listed by Portères (1959). Collectrions: FRENCH POLYNESIA: Raiatea, St. John 17310 (K!); Mongareva Isl., St. John 14459 (K drawing!).

Sources: Howcroft, N.H.S. 1984. A Guide to the monocotyledons of Papua New Guinea. R.J. Johns \& A.J.M. Hay (eds.) 4. The Orchidaceae (in part): Forestry Department PNG, University of Technology: 129, fig. 71. Portères, R. 1954. Le Genre Vanilla et ses Espèces: 239-242, fig. 109.

Vanilla taiwaniana S.S. Ying. See in excluded species.

Vanilla tiarei Costantin \& Bois $=\boldsymbol{V}$. tahitiensis

V. tisserantii Portères $=\boldsymbol{V}$. seretii

V. tolepephora Ridl. $=$ ?V. griffithii
98. V. trigonocarpa Hoehne in Arq. Bot. Estado São Paulo, n.s., 1(6): 126 (1944). Type: Brazil, Pará, outskirts of Belem do Pará, 23 Nov. 1926, Ducke s.n. (holo. RJ 19445!).

V. pauciflora R.L. Dressler in Orquideología 13(3): 229 (1979). Type: Panama, Dressler 5290 (holo. US).

Distribution: Costa Rica, Panama, Colombia and Brazil.

A very distinct Vanilla known from wet forests in Central America, Colombia, and from the delta of the Amazon River. The main difference between $V$. trigonocarpa and $V$. pauciflora is the more trilobed lip of $V$. trigonocarpa. The plant seems to be related to $V$. espondae from Colombia, and perhaps to $V$. sprucei. Collection: COSTA RICA: Catling \& Brownell C24.1 (AMES!).

99. V. utteridgei J.J.Wood in Orchid Rev. 110: 232 (2002). Type: New Guinea, Papua, Mimika Regency, Kuala Kencana, Utteridge 456 (holo. K).

Distribution. New Guinea: S Papua only.

Closely allied to $V$. kempteriana, differing in its pubescent column and the two lateral calli in front of the penicillate callus.

V. uncinata Huber \& Hoehne $=\boldsymbol{V}$. odorata

V. vanilla $(\mathrm{L}$.) H. Karst. $=$ ? V. mexicana

V. vanilla $(\mathrm{L}$.) Huth $=$ ?V. mexicana

100 V. vellozii Rolfe in J. Linn. Soc. Bot. 32: 467 (1896). Type: Brazil, Glaziou 14302 (lecto. K! designated here).

V. chamissoins var. brevifolia Cogn., Fl. Bras. 3(4): 149 (1893). Based on Epidendrum vanilla Vellozo, F.Flum. Ic. 9: t. 1 (1827).

$V$. argentina Hicken in Anales Soc. Ci. Argent: 235. 1916; Vanilla Argent. 3 (1917). Types: Argentina, Formosa, Pilcomayo, Cáceres (not seen; 3 immature fruits only); Gran Chaco, $J$. Domínguez 307, 25-IX-1915, Inst. Darwiniano

Distribution: Brazil, Paraguay, Argentina.

This species has been confused with $V$. chamissonis but it is easily distinguished by its shorter segments, especially its very broad, subentire lip. $V$. chamissonis has a very elongate midlobe to the lip 
and longer tepals. It seems to be common in coastal areas. However, they are probably closely related, sharing with $V$. calyculata the conspicuous calyculus, especially on ovaries whose flowers have just faded.

Collections: BRAZIL: Parana, Dusén 16125 (AMES!). Rio de Janeiro, Glaziou 11621 (K! without flowers). Sao Paulo, van der Berg s.n. (AMO slides!). PARAGUAY: Fiebrig 564 (K! AMES! G7 889/113!).

101. V. verrucosa Hauman in An. Mus. Nac. Buenos Aires 29: 365-366 (1917). Type: Argentina, Misiones, Piray, March 1901, Kermes 127 (holo. Herb. Min. Agr. 6358; not seen)

V. verrucosa is distinguished from its close relatives by its very small dimensions and the triangular acuminate midlobe of the lip. Andrés Johnson (pers. com.) indicates that the type specimen is sterile and that the species has not been recollected. He stated that is not improbable that $V$. verrucosa is an atypical form of $V$. rojasiana Hoehne (=V. angustipetala Schltr.). We suspect that the original description might have been based on an immature bud.

The small members of the membranaceous group found in Brazil and Argentina are a taxonomically difficult complex, due to the scarcity of material, poor preservation or condition of the type specimens, and the similarity of the described taxa.

Vanilla angustipetala (syn. V. rojasiana) and $V$. parvifolia have almost identical habits, inflorescences and flowers, except for the presence of lamellae in $V$. parvifolia and rows of warts on the lip in $V$. angustipetala. The plant illustrated in t. 22 of Hoehne's Flora Brasilica, and identified as V. parvifolia, shows longer, more acute leaves, longer inflorecences with more flowers and more acuminate sepals and narrow midlobe of the lip, approaching to $V$. edwallii or $V$. organensis.

Source: Portères, R. 1954. Le Genre Vanilla et ses Espèces: 188.

\section{V. viridiflora $\mathrm{Blume}=\boldsymbol{V} \cdot$ planifolia}

102. V. walkeriae Wight, Icon. Pl. Ind. Orient. t. 932 (1845). Type: SRI LanKa, Walker s.n. (holo. K!).

Distribution: India and Sri-Lanka.

This species has been repeatedly confused with the other Indian leafless species such as $V$. wightii. $V$. walkeriae is similar to the Indian Ocean leafless species $V$. phalaenopsis and V. madagascariensis, with large, white flowers bearing very broad petals and 2 longitudinal rows of hairs on the lip disc. It has been confused with $V$. wightii. Part of the confusion can be traced to a mixture of both leafless Sri Lankan species on the type sheet of $V$. walkeriae at Kew.

Collections: SRI LANKA: Champion s.n. (K-LINDL!); Diraviam \& Anthony RHT 27780 (K!); Mueller-Dombois et al. s.n. (K!) \& 69042619 (K!); Thwaites s.n. (K!) \& 2964 (K!); Cramer 4664 (K!). INDIA: Fisher 1011a (K!); Wight s.n. (K!).

Sources: Trimen, H. 1898. Handb. Fl. Ceylon 4: 220; Seidenfaden, G. 1983. The Flora of the Tamilnadu Carnatic. Orchidaceae: 1570-1571, pls. 698 and 699; Pradhan, U.C. 1976. Indian Orchids: Guide to Identification and Culture 1: 151; Jayaweera, D.M.A. 1981. Orchidaceae. A Revised Handbook to the Flora of Ceylon 2: 331.

103. V. wariensis Schltr. in Repert. Sp. Nov. Regni Veg. Beih. 1: 30 (1911). Type: Papua New Guinea, Schlechter 19928 (holo. B†).

Distribution: Endemic to Papua New Guinea.

O'Byrne (1994) mentioned that it is common to the North of the Owen Stanley Range. It can be distinguished from other New Guinean vanillas by its very large leaves $27-35 \times 5-7 \mathrm{~cm}$.

SourCES: Portères, R. 1954. Le Genre Vanilla et ses Espèces: 212; Howcroft, N.H.S. 1984. A Guide to the monocotyledons of Papua New Guinea. R.J. Johns \& Hay, A.J.M. (eds.) 4. The Orchidaceae (in part): Forestry Department PNG, University of Tchnology. p. 126; O’Byrne, P. 1994. Lowland Orchids of Papua New Guinea. SNP Ltd. p. 9.

\section{$V$. weberbaueriana $=\boldsymbol{V}$. ruiziana}

104. V. wightii Lindl. ex White, Icon. P1. Ind. Orient. sub t. 931 (1844). Type: S India, Wight 2091 (holo. $\mathrm{K}-\mathrm{LINDL}$ ! iso. $\mathrm{K}$ !).

V. aphylla Wight., Icon. P1. Ind. Orient. t. 931 (1845), non Blume (1825). Based upon Travancore, Trevandrum, Wight s.n. (K).

V. wightiana Lindl. in Hook.f., Fl. Brit. India 6: 90 (1890), sphalm. pro V. wightii.

DistRibution: India (Deccan) and Sri Lanka.

This species has been confused in the literature. The type collections at $\mathrm{K}$ consist of different, separated 
fragments on three sheets, some fragments seem to be referable to Wight's concept of $V$. wightii, and others to $V$. walkeriae. Vanilla wightii is closely related to $V$. aphylla and $V$. calopogon, while $V$. walkeriae is a member of the $V$. madagascariensis group. In $V$. wightii the inflorescences are short, with about 3 flowers, the lip has two rows of hairs from the base to the sides of the crest, which is like a large penicillate callus continuous with an apical strip of hairs. A fragment in each one of the isotypes at $\mathrm{K}$ shows an elongate inflorescence, with a thick fruit and many protuberant scars, lacking bracts, typical of $V$. walkeriae, in which the bracts are deciduous. Seidenfaden (1983) illustrated a specimen of $V$. walkeriae with narrow segments, but lacking the hirsute lip apex characteristic of the $V$. aphylla complex. Pradhan (1976) also illustrated $V$. walkeriae rather than the true $V$. wightii. A good illustration of $V$. wightii can be found in Abraham and Vatsala (1981). Although both species are leafless, $V$. wightii and $V$. walkeriae belong to different lineages of the genus.

Vanilla walkeriae resembles closely V. roscheri and its close allies, in having large, white flowers. Collections: WITHOUT LOCALITY: cult. Hort. Bot. Reg. Kew a. 191 (K!, in part). SRI LANKA: C.V. 2964 (K! watercolor).

Sources: Abraham, A. \& Vatsala, P. 1981. Introduction to Orchids: 500-502. Seidenfaden, G. 1983. The Flora of the Tamilnadu Carnatic. Orchidaceae: 1570, pl. 698; Pradhan, U.C. 1976. Indian Orchids: Guide to identification and Culture 1: 151.

\section{V. wrightii Rchb. f. $=\boldsymbol{V}$. bicolor}

105. V. yersiniana Guillaumin \& Sigaldi in Bull. Mus. Hist. Nat. sér. 2, 36: 162 (1964). Type: VIETNAM (Annam), road from Yersin to Hon ba, Suoi Dao, cult. Suoi Dao, May 1963, de Sigaldi 362 (syn. P) \& 309 (syn. P).

Distribution: Thailand, Vietnam.

A common species in Indochina which is readily distinguished by its lanceolate, long-acuminate leaves and whitish flowers with scarcely developed papillae on the lip apex. The narrow, elongate funnelshaped flowers are different from those of most other Asian species, except its close allies $V$. montana, $V$. albida and $V$. andamanica. Good photographs and illustrations can be found in Seidenfaden and Wood (1992) and Seidenfaden (1978, fig. 87) who considered it as conspecific with $V$. albida, a different species from Java. $V$. albida has greener tepals and different papillae at the apex of the lip (see pictures in Comber, 1990).

Collections: Thailand: Larsen \& Larsen 33174 (AAU! K!); Kerr 0805 (K!), 0805A (K!), s.n. (K!); Hull 671 (K! sterile).

Sources: Seidenfaden, G. \& T. Smitinand 1959. The Orchids of Thailand: a preliminary list, part 1: 60 (as V. sp. Kerr 805 and 805A); Seidenfaden, G;. 1978. Orchid Genera in Thailand VI. Dansk Bot. Arkiv. 32(2): 140-141, fig. 87; Averyanov, L.V. 1994. Identification Guide to Vietnamese Orchids: 76 (as $V$. albida); Seidenfaden, G. \& J.J. Wood, 1992. Orchids of Peninsular Malaysia and Singapore pages?? Comber, J.B. 1990. Orchids of Java: 76; Averyanov, L.V., N.T. Hiep, P.K. Loc \& A.L. Averyanova. Preliminary orchid checklist of Cao Bang Province. Lindleyana 15(3): 163 (as V. albida).

106. V. zanzibarica Rolfe in Bull. Misc. Inform. Kew 1906: 116 (1906). Type: ZanziBAR, on the Wanda, near Dunga, Lyne s.n. (holo. K!).

Distribution: ?Uganda, Kenya, Tanzania, including Zanzibar and Pemba.

Vanilla zanzibarica has been treated as a synonym of V. ramosa (e.g. Cribb, 1984; Stewart, 1996). However, the specimens from East Africa usually have much broader leaves, the midlobe of the lip is broader, obtuse, apiculate and conduplicate, and the total length of the lip is longer (up to $25 \mathrm{~mm}$ long). The conduplicate lip is more similar to that of $V$. crenulata, although not so high and gibbose, but $V$. zanzibarica lacks the foliaceous bracts of $V$. crenulata. Leaf shape and size approach those of $V$. ramosa, but the flowers are much larger. Vanilla zanzibarica seems to be geographically separated from the other members of this complex, being restricted to a small area in the Usambaras, Pemba and Zanzibar in Tanzania and to the Shimba Hills in Kenya.

Collections: TANZANIA: Moreau 408 (K!); Holtz 159 (K!); Greenway in Moreau 408 A (K!); Greenway 4684, 7043 (K!); Mücke s.n. (K!); Zimmermann s.n. (K!); Borhidi et al. 86353 (K!).; Zanzibar, Vaughan 1254 (K!); Williams 64 (K!); Fawcras 3121 (K!); Greenway 1297, 2606 (K!); Toms s.n. (K!). Pemba, Soaper H45/30 (K!); Williams 110 (K!). KENYA: Luke 
3847 (K!); Luke \& Robertson 2393 (K!); Magogo \& Glover 583 (K!).

SOURCES: Portères, R. 1954. Le Genre Vanilla et ses Espèces: 200-201; Cribb, P. 1984. Flora of Tropical East Africa. Orchidaceae 2: 261, 263 (as V. ramosa); Stewart, J. 1996. Orchids of Kenya: 89-90 (as $V$. ramosa).

\section{EXCLUDED AND POORLY UNDERSTOOD SPECIES}

Vanilla carinata Rolfe in J. Linn. Soc. Bot. 32: 468 (1896). Type: Brazil. Organ Mountains, Miers s.n. (holo. K!).

The type of this species consists of a single sheet with several poorly-preserved, large flowers (sepals up to $7 \mathrm{~cm}$ long) and no leaves or stems. The rachis bears two ovaries with a conspicuous calyculus, and the lip seems to be longer than sepals. It could be $V$. chamissonis or perhaps $V$. vellozii, but the material is insufficient to determine its correct identity. We are inclined to think that the "strongly keeled" lip apex described by Rolfe is an artifact due to the poor preservation of the flowers.

Hoehne (1945) listed it as a synonym of $V$. planifolia.

Vanilla taiwaniana S.S. Ying in Quart. J. Chinese Forest. 20, 2: 55 (1987). Type: Taiwan, Taichuang, July 1984, F.S. Ho s.n. (holo. not located).

A poorly known species. The short description suggests that it could be a synonym of Erythrorchis ochobiensis (Hayata) Garay, but with its green colour and developed leaves it may belong to a Pseudovanilla.

ACKNOWLEDGMENTS: We thank the curators of the following herbaria for the loans or permitts to examine their collections: AMES AMO, BM, BR, CAS, CEN, CR, ENCB, G, HAC, HAJB, HB, K, LE, MA, MEXU; MG, MO, NY, P, RJ, US, UVAL, W, XAL. We would like to thank J. Ackerman, the late J.B. Comber, Andrés Johnson, G. Salazar, A. Toscano de Brito and Bill Goldner who offered important information, opinion or material.

\section{LiTERATURE CITED}

Comber, J.B. 1990. Orchids of Java. Bentham-Moxom Trust, Royal Botanic Gardens, Kew. pp. 74-76.

Christenson, E. 1995. The long-lost Vanilla bicolor. Amer. Orch. Soc. Bull. 64(8): 844-847.

Correll, D.S. 1951. Orchids of North America north of Mexico. Chronica Botanica, Waltham, Mass. pp. 155163.

Cribb, P.J. \& P.F. Hunt.1984. Vanilla. In Polhill R. (ed.), Flora of Tropical East Africa Orchidaceae 2: pp. 258-263.

Dunsterville, G.C.K. \& L.A. Garay. 1959-1976. Venezuelan Orchids Illustrated. 1-6. A. Deutsch, London.

Hoehne, F.C. 1945. Flora Brasilica 12, 2. Orchidaceas. Secretaría de Agricultura, Industria e Comércio de Sao Paulo, Brasil, pp. 3-36, t. 1-29.

Klotzsch, J.F. 1845. Ueber die Arten der Gattung Vanilla. Bot. Zeitung (Berlin) 4: 561-567.

La Croix, I. \& P.J. Cribb. 1995. Flora Zambesiaca Orchidaceae. 1. Balkema, Rotterdam.

Luer, C. 1972. The Native Orchids of Florida. New York Botanical Garden, pp. 68-69.

Porterès, R. 1954. Le genere Vanilla et ses espèces: pp. 94290. In G. Bouriquet, ed., Le Vanillier et la Vanille dans le Monde. Enc. Biol. 46. Ed. Paul Lechevalier, Paris.

Rolfe, R.A. 1896. A revision of the genus Vanilla. J. Linn. Soc. 32: 439-478.

Roubik, D.W. \& J.D. Ackerman. 1987. Long-term ecology of euglossine orchid-bees (Apidae: Euglossini) in Panama. Oecologia (Berlin) 73: 321-333.

Dressler, R.L. 1981. The Orchids. Natural History and Classification. Harvard University:Press, Cambridge, $332 \mathrm{p}$.

1993. Phylogeny and Classification of the Orchid Family. Dioscorides Press. Portland, Oregon, 314 p.

Seidenfaden, G. 1992. Orchids of Indochina. Opera Botanica 114: 71-72.

Soto Arenas, M.A. \& E. Alvarez-Buylla. in prep. Notes on the floral biology of Mexican Vanilla (Orchidaceae) and the evolution of pollination systems in the genus.

Stewart, J. 1996. Orchids of Kenya. St .Paul Bibliographies, Winchester.

Summerhayes, V.S. 1968. Flora of West Tropical Africa. Orchidaceae, ed. 2. Crown Agents, London, pp. 205-206.

Szlatchetko, D.L. \& S. Olzewski. 1999. Flore du Cameroun Orchidaceae 1: 279-294.

van der Pijl, L. \& C.H. Dodson. 1966. Orchid flowers. Their pollination and evolution. Univiversity-of Miami Press, Coral Gables, Florida, 23, 77, 125. 